WIDER Working Paper 2016/157

\title{
Understanding and characterizing the services sector in South Africa
}

An overview

Haroon Bhorat, François Steenkamp, Christopher Rooney, Nomsa Kachingwe, and Adrienne Lees*

December 2016 
Abstract: The South African services sector is large and growing. This coupled with declining employment shares in manufacturing and mining (i.e. deindustrialization) suggests that South Africa is a de facto service-orientated economy. Employment patterns in services reveal a segmentation that is characterized by high-productivity, high-wage services, low-productivity, low-wage services, and government services. There has been sustained growth in services exports in the post-1994 period but the composition is biased toward traditional services. Increased entry into developing country markets is characterized by increasingly sophisticated services. A key driver of export growth is the expansion of foreign direct investment into developed country markets, and increasingly, into developing country markets, particularly African markets.

Keywords: services, economic development, South Africa, economic growth, structural change JEL classification: L80, O14, O55

\footnotetext{
* Development Policy Research Unit, School of Economics, University of Cape Town; haroon.bhorat@uct.ac.za.

This study has been prepared within the UNU-WIDER project on 'Industries without smokestacks', which is part of a larger research project on 'Jobs, poverty and structural change in Africa'.
}

Copyright (C) UNU-WIDER 2016

Information and requests: publications@wider.unu.edu

ISSN 1798-7237 ISBN 978-92-9256-201-4

Typescript prepared by Lesley Ellen.

The United Nations University World Institute for Development Economics Research provides economic analysis and policy advice with the aim of promoting sustainable and equitable development. The Institute began operations in 1985 in Helsinki, Finland, as the first research and training centre of the United Nations University. Today it is a unique blend of think tank, research institute, and UN agency—providing a range of services from policy advice to governments as well as freely available original research.

The Institute is funded through income from an endowment fund with additional contributions to its work programme from Denmark, Finland, Sweden, and the United Kingdom.

Katajanokanlaituri 6 B, 00160 Helsinki, Finland

The views expressed in this paper are those of the author(s), and do not necessarily reflect the views of the Institute or the United Nations University, nor the programme/project donors. 
After the lost decades of the 1980s and 1990s in Africa, the post-2000 period has been characterized by rapid economic expansion. However, the sustainability of this growth has come under increasing empirical and analytical scrutiny. Sustained economic growth and development inevitably involves the process of structural transformation-the shift from low-productivity agricultural activities toward high-productivity industrial and agricultural activities. As such, the extent to which the continent, and the countries that comprise it, is undergoing or indeed may have undergone structural transformation, has been investigated in the literature. Rodrik (2014) argues that the traditional engine of economic development-the process of structural transformation driven by industrialization within which the manufacturing sector is at the corehas not thus far been a key component of the African economic growth recovery. McMillan and Harttgen (2014) find evidence of structural transformation, but note that the expansion of manufacturing has not been significant, whereas the growth in services has been sizeable.

Essentially, the post-2000 growth period in Africa has witnessed the declining importance of agriculture, a significant increase in the importance of services, and a somewhat stagnant performance in manufacturing (Bhorat et al. 2016). The question then arises as to whether structural change, less dependent on a manufacturing-driven growth but more biased toward the services sectors, can provide an alternative avenue for sustained economic growth and development in Africa. The notion that the continent, and South Africa in particular for our case study here, may indeed be able to grow and structurally transform through a variety of services industries - is an intriguing and crucial research question.

As part of a multi-country project exploring the above-mentioned question, this paper aims to examine the impact and potential of generating a services industry-led growth path in South Africa. South Africa offers a unique case study in that while it is formally classified as a semiindustrialized upper-middle income country, it has recently exhibited signs of deindustrialization. In conjunction with the decline of industry, there has been a rapid and significant growth across a range of services sectors. Furthermore, from a policy standpoint, the targeting of the business and tourism services sectors in South Africa's National Development Plan and the New Growth Path point to a recognition of the economic potential offered by these sectors by policy-makers in South Africa.

The paper proceeds as follows: In Section 2, we examine the literature that links economic development and services-led growth. Section 3 briefly describes the manner in which we conceptualize the services sector, and the data utilized to analyse this sector. In Sections 4 and 5 we document the development of various service industries, as well as agro-processing activities, and provide an estimate of their significance in the South African economy. In Section 4 we examine the contribution of the services sector to the South African economy and examine the segmentation of this sector using a labour market approach. In Section 5 we analyse the export potential of the South African services sector as well as the agro-processing industry. Section 6 provides a description of public policies that have had an impact on the broad sector performance. Section 7 concludes the analysis by locating service industries in terms of their employment and export potential. 


\section{Literature review: services-led growth and economic development}

\subsection{Introduction}

The East Asian growth miracles, including China, were driven by industrialization and manufacturing exports. Consequently, manufacturing is often seen as the key route to increasing national per capita income levels. However, recent evidence suggests that global demand for manufactured goods is declining, and economic conditions are less conducive to building a development path based on fast-growing manufacturing exports (Rodrik 2014). Thus, there is a distinct possibility, if these global demand trends in manufacturing continue, that manufacturing and manufacturing exports in particular may play a distinctly less central role in shaping the economic growth trajectories of developing countries in the future. In this vein then, as the scope for manufacturing-led growth possibly wanes, the services sector as an engine of growth needs closer examination. The South Asian experience is instructive here, and gives evidence that services can drive development.

\subsection{The South Asian experience}

South Asia's recent growth performance has almost matched that of East Asia. However, growth in this region has been driven by services as opposed to manufacturing. In the 1980s, the services sector in South Asia accounted for less than 40 per cent of gross domestic product (GDP). This grew to over 50 per cent in India, Pakistan, Bangladesh, and Sri Lanka, and 49 per cent in Nepal in 2005 (Noland et al. 2012). These figures are akin to what industry contributes to East Asian growth. Not only are services now the largest sector in these economies, but they also account for the greatest per cent of GDP growth. In India, the Maldives and Sri Lanka, approximately 60 per cent of overall growth from 2000-10 was attributed to services (Noland et al. 2012). This represents a higher share of services in GDP and faster services sector growth than East Asia, despite East Asia being richer and experiencing moderately faster growth over the period.

Further analysis of service sector growth in South Asia reveals a dichotomy within the sector between modern impersonal services and traditional personal services. ${ }^{1}$ A decomposition of the services sector within this region shows that modern impersonal services are growing faster than traditional personal services. For instance, in Bangladesh, India, and Sri Lanka, modern services grew at an average growth rate in excess of 12 per cent per annum between 2000 and 2006. The corresponding growth rates in traditional services for these countries was under 10, 8, and 4 per cent, respectively (Ghani 2009). Furthermore, India, Pakistan, and Sri Lanka are significant positive outliers when comparing the share of IT and IT-enabled services exports in total exports of goods and services with the rest of the world (Ghani 2009). In contrast, the share of traditional services, such as tourism and transportation, in total exports, is not significantly different from the global norm (Ghani 2009).

This services-led growth has challenged the traditional notion that the process of industrialization, and hence the development of a manufacturing sector, is a necessary element of structural transformation and economic development. Previously, services were believed to be restricted to the domestic market and therefore unable to contribute significantly to growth. A haircut, restaurant meal, or legal consultation, had to be conducted in person, and there was little

\footnotetext{
${ }^{1}$ Traditional services include services such as trade, hotels and restaurants, education, and transport and health, that often require face-to-face interaction and where ICT use is limited. Modern services include computer and information services, financial and business services, and communication.
} 
potential for scaling up these activities and exporting them. Thus, the development literature has typically thought of the services industry as comprising low-productivity firms that offer lowpaying, menial jobs and provide non-tradeable services (Mishra et al. 2011).

However, it can be argued that technological change has fundamentally altered the nature of structural transformation and the manner in which economies develop. Technology has removed the need to supply services in person. This has enabled the tradability of certain services across borders as the two parties involved in the transaction do not have to be in the same space (Mishra et al. 2011). For instance, loan applications and approvals can be conducted online by someone working in another country, and hospital records can be stored and updated on a remote server. Transportability means that services are no longer restricted by time or proximity, and can be delivered over great distances with little to no deterioration in quality (Ghani and O'Connell 2014). In fact, advances in telecommunications have brought the cost of trading services down faster than that of trading goods. Finally, most modern services are delivered electronically, and thus do not face the same trade barriers, such as tariffs or customs, that are placed on goods (Ghani 2009). A more liberal global trade regime for services has contributed to rapid market expansion.

Interestingly, developing countries seem to be focusing on the production of tradeable services more than developed nations. The most obvious example is that of India, which has of course emerged as a leading producer of IT and IT-enabled services, despite having a relatively small domestic market. Researchers argue that the Indian example is indicative of a much larger, future global trend. More and more personal services are able to be delivered impersonally as information technology expands, thus increasing global trade (Blinder 2006).

However, these technological changes are common globally, and cannot alone explain South Asia's exceptional growth path. The emergence of South Asia, and India in particular, as a leading services exporter has been ascribed to a combination of effective market integration, the availability of skilled labour, and supportive institutions and infrastructure (Ghani 2009). Firstly, South Asian countries liberalized services trade faster than East Asia, which attracted both domestic and foreign investment in the sector. Secondly, India's spending on tertiary education is comparatively high. The large number of skilled graduates, with a good reputation for their English language abilities, made India suitable for investment in the fast-growing information and communication technology industries. Furthermore, India's institutions affecting services were more conducive to business than those that affected goods (Ghani 2009). For instance, states in India with stronger property rights also demonstrated stronger services-led growth. Finally, while manufacturing relies on sound infrastructure for the transportation of goods, services rely on electronic delivery. India's policies toward telecommunications in the 1990s facilitated private sector investment and the growth of competitive broadband telecommunications markets (Ghani 2009).

\subsection{Evidence of economic transformation}

A key question from a developing country perspective, especially in the case of African countries, is whether service sector growth can contribute to positive economic transformation. Historically, the developmental literature has argued that this is not the case. Firstly, many of the fast-growing services industries require medium to highly skilled labour. Thus, depending on the skill intensity of the sector and the availability of suitable workers, the ability of the services sector to generate jobs for the majority of the unemployed may be constrained. Secondly, services sector activities were typically thought of as less productive than manufacturing, largely due to the informal and personal nature of many services (Khanna et al. 2016). Finally, services 
growth tends to be geographically concentrated in wealthier, urban regions and thus the benefits of growth are not extended to the poorest regions.

In contrast, recent literature has argued that services can contribute to positive economic transformation, and the South Asian case somewhat attests to this. Bosworth and Maertens (2009) found that labour productivity, in absolute terms, is higher in the services sector than in the industrial sector for India, Nepal, Pakistan, and Sri Lanka. In contrast, labour productivity in manufacturing is substantially higher in East Asia. This supports the idea that South Asian growth is characterized by moving labour from low-productivity agricultural activities to highproductivity services. Similarly, labour productivity growth in the services sector has been higher than in manufacturing for India, Pakistan, and Sri Lanka (Bosworth and Maertens 2009).

Jobless growth is a primary concern for late developers, particularly given the youth bulge experienced by many of these nations. In a study of over 100 countries, Ghani and O'Connell (2014) found that the capacity for the industrial sector to create jobs has been declining over time. In contrast, the service sector is absorbing more labour and at earlier stages of development. Evidence suggests that the services sector has generated jobs at a faster pace than other sectors in India and Pakistan, while services job creation in Bangladesh and Sri Lanka narrowly lagged behind manufacturing (Ghani 2009). Furthermore, there is evidence that the services industry in South Asia has experienced higher growth rates in wages than agriculture and manufacturing.

With respect to the poverty-reducing effects of service-led growth, Ghani (2009) found that growth in the services sector displays a stronger correlation with poverty reduction than growth in manufacturing or agriculture for a sample of 50 developing nations. At the state level in India, the same pattern was displayed, with better rates of poverty reduction coming from states that attracted more IT-related investment (Ghani 2009). Growth in the services sector supports poverty reduction through two avenues: firstly, the sector creates new jobs, and, secondly, the income from services jobs, when spent, increases demand for goods and services. This contributes to further increases in employment.

\subsection{Potential for other low-income countries}

Although India is the poster child for modern services growth, several other low-income countries have experienced similar if not stronger growth in services. For instance, between 2006 and 2010, Rwanda, Ethiopia, and Nigeria all topped India's average annual services growth rate. ${ }^{2}$ A report by Khanna et al. (2016) for the Overseas Development Institute found that Kenya has rapidly asserted itself as a regional services hub. Kenyan services exports more than tripled from US $\$ 1.9$ billion in 2005 to US $\$ 4.9$ billion in 2012, and thus experienced more dynamic growth than goods exports. In addition, Kenya is ahead of similarly wealthy countries in terms of the share of services in trade, with a 44 per cent share in 2012 compared to the average of 33 per cent (Khanna et al. 2016). These exports are dominated by transport and communications (including ICT), followed by travel, insurance, and financial services. The performance of tourism services is relatively weak compared to countries with similar income levels.

Egypt has emerged as a leading supplier of IT services for the region and European markets. To succeed, they have leveraged their proximity, geographically, linguistically, and culturally, to wealthy Persian Gulf countries, as well as their geographic proximity to Europe (Engman 2010).

\footnotetext{
2 This is based on the authors' own calculations using data from the World Bank's World Development Indicators (World Bank 2016).
} 
Several leading IT companies, such as HP and Microsoft, have built software application development centres in Egypt, while some telecommunications companies have opened support centres. This success is attributed to a high number of multilingual, technologically skilled graduates, cheaper labour and input costs, and a political will to improve the business environment (Engman 2010).

Another example of an emerging export niche for developing countries is health services. This includes the cross-border movement of patients, temporary movement of health professionals to deliver services internationally, the opening of branches or clinics abroad, and the technological provision of services across borders, such as a radiologists based in Asia servicing American hospitals (Cattaneo 2010). Historically, the North has serviced the South as patients sought higher-quality treatment. However, this is shifting as medical services improve in developing countries. Developing countries can leverage a comparative cost advantage due to lower labour costs and favourable exchange rates, and offer attractive convalescence resorts (Connell 2006). This, of course, is conditional on an assumption of comparable levels of quality. Many developing countries suffer from low hospital and clinic density and high mortality rates. It has been argued that the income from trade in health services could contribute to the alleviation of these shortages.

Countries such as Thailand and Malaysia have emerged as significant global health exporters, largely catering to their neighbouring countries. Thailand in particular has experienced rapid growth in medical tourists, from almost none in 2000 to over 450,000 in 2009 (NaRanong and NaRanong 2011). South Africa has been hailed as a leading destination for cosmetic surgery, as costs can be less than half of those in America, from where most patients originate. India is also known to be a major centre for medical tourism, and emphasizes its lower costs and shorter waiting lists (Connell 2006).

The essential problem with services as a route to development is that the most productive, growth-stimulating service sectors appear to require highly skilled labour. For a farm worker to be productive in an industry like information technology, s/he would require many years of education and training. Whereas the same farm worker can become a more productive manufacturing worker fairly easily (Rodrik 2014). Ultimately, skills portability gaps are on average more easily closed in moving from agriculture to manufacturing, than from agriculture to highend services. Therefore, it has been argued that African countries will struggle to create an environment that will exploit the growth potential of the services sector. Given that many highproductivity services jobs rely on highly skilled labour, poor levels of human capital accumulation in many low-income countries is likely to constrain growth through the services sector.

However, certain services sectors do present the potential to be major employers of low- to medium-skilled labour. One such sector is transport, termed the 'ultimate facilitator' by the World Bank (Khanna et al. 2016). Transport services facilitate international trade, stimulate economic growth and regional integration, and extend economic opportunities to rural areas. Moreover, good transportation networks extend access to health and education facilities. Employment opportunities at the lower-skilled end of the spectrum include service operators, such as truck or taxi drivers, road maintenance, traffic management, and road and infrastructure construction (Khanna et al. 2016). At a broader level, the transport sector has numerous linkages to other spheres of the economy and its services are crucial to ensuring the productivity and competitiveness of manufacturing industries.

Furthermore, the development of transportation networks can contribute to positive social outcomes such as improved enrolment of girls, as access to education expands. An example 
from Kenyan flower exports highlights the structurally transformative nature of this sector. Kenya has emerged as one of the world's largest exporters of cut flowers, many bound for Europe. This industry is a key earner of foreign currency, and a large employer of women from poor rural backgrounds who receive basic training (Khanna et al. 2016). The success of this industry can partially be attributed to improvements in the Kenyan national airline following privatization, as well as the development of efficient transportation networks from farms, with refrigerated facilities, as well as upgraded airports.

Another industry with strong pro-poor growth potential is tourism. Employment can be generated across a wide range of skills, from cleaning and catering staff to professional management staff and guides. Furthermore, there are multiple backward-linked industries that could benefit from a strong tourism sector, for instance transportation, handicrafts, and agricultural supplies. The potential of these indirect effects depends on the tendency for the tourism sector to source goods and services locally (Khanna et al. 2016). For example, in Kenya, tourism accounted for approximately 12 per cent of GDP in 2014 and had significant spillover effects. One of these is the upgrading of international airports in Nairobi and Mombasa, as well as the construction of new domestic airports. This has meaningfully enabled the growth of other sectors, such as the highly profitable flower exports (Khanna et al. 2016).

Another important concern is whether services-led growth can be sustained. Blinder (2006) argues that services display enormous potential and the current degree of globalization is only the beginning. As the number of services produced and traded globally expands, the opportunities for developing countries to find alternative niches and specialize their production also expands. Thus increasing globalization offers new possibilities for developing comparative advantages in services, rather than solely in manufacturing or agriculture.

\section{Methodology and data}

In the analysis below we present a descriptive overview of the service sector and the various service sub-industries within the South African economy. We focus predominantly on the post2000 period, although where necessary and feasible we employ a longer time period. It is important to note that we examine the service industries in relation to the manufacturing sector as a whole, in order to assess the sector's viability as an alternative source of structural transformation to manufacturing.

Following the conceptual approach to services presented by Ghani and Kharas (2009) we examine the service industries by grouping them into two groups: firstly, modern tradeable services, and, secondly, traditional non-tradeable services. Based on available data at a given level of aggregation, the former comprises finance and insurance services, business services, and communication services. The latter comprises government services, transport and storage services, wholesale and retail trade, accommodation and catering services, and other community, social, and personal (CSP) services. We do this in order to unpack the varying performance and characteristics of the two since it is argued that the former is more dynamic and able to facilitate structural change in an economy.

In order to examine the services sector in South Africa we employ a variety of datasets. To interrogate labour market aspects of the services sector we analyse the Labour Market Dynamics Survey (LMDS) from Statistics South Africa. The LMDS is an annual dataset that is comprised of data from the Quarterly Labour Force Surveys in a calendar year. It is a household survey that captures detailed labour market information. 
Broad industry trends for GDP, employment, and productivity are analysed using data from Quantec. Quantec is a private consultancy that collects and compiles macro and regional economic, industry, and international trade data from a variety of statistical sources in South Africa (e.g. Statistics South Africa, South African Reserve Bank). The advantage of using Quantec data is that it allows for a slightly more disaggregated measurement of service industries than data available from Statistics South Africa.

Data for service exports is obtained from three sources. More aggregated service export data available for longer periods is sourced from the South African Reserve Bank (SARB) and World Bank's World Development Indicators. Bilateral and highly disaggregated service export data is obtained from the World Bank's Trade in Services Database (TSD) developed by Francois and Pindyuk (2013). The advantage of using the TSD is that the highly disaggregated and bilateral nature of the data allows one to investigate service export dynamics in more detail.

Data enabling the analysis of the South African tourism industry is obtained from Statistics South Africa's Tourism Satellite Account-2005 to 2012 and 2013 to 2014. The analysis is further complemented by data from the nationally representative Quarterly Labour Force Survey of South Africa. It is worth noting that a major problem facing researchers trying to analyse the tourism industry in South Africa is the paucity of reliable data. As such, Statistics South Africa has generated the Tourism Satellite Accounts in order to better measure the contribution of the industry to the South African economy.

In order to analyse processed agriculture and horticulture, we use trade data at the 6-digit level of the Harmonized System from UN COMTRADE World Integrated Trade Solutions. The highly disaggregated nature of this data allows for a detailed analysis of South African agriculture exports.

In order to unpack broad bilateral trends in foreign direct investment, particularly outbound foreign direct investment (FDI) from South Africa, we employ data from the UNCTAD Bilateral FDI Statistics. The case study analysis of the three South African firms in Section 5.4.2 is informed by financial data from the company websites.

\section{The role of services in the South African economy}

In light of the notion that service industries can be engines for growth, this section studies the role of these industries in the South African economy. The analysis starts by detailing the contribution of the services sector (and its sub-sectors) to GDP, employment, and productivity.

\subsection{Contribution of the services sector to the economy}

\section{Gross domestic product}

Figure 1 shows the contribution of the services sector relative to the other major sectors of the economy for the period 2000 to $2014 .^{3}$ It is clear that the services sector, as an aggregate, is the major sectoral contributor to South Africa's GDP. Furthermore, the sector's share of GDP in the economy has increased over the period.

\footnotetext{
3 The services sector aggregate is comprised of the following sub-sectors or industries: trade, catering and accommodation services, wholesale and retail trade, transport and storage, communication, finance and insurance, business services, general government services, and other community, social, and personal services (CSP).
} 
Figure 1: Relative contribution of sectors to GDP, 2000-14

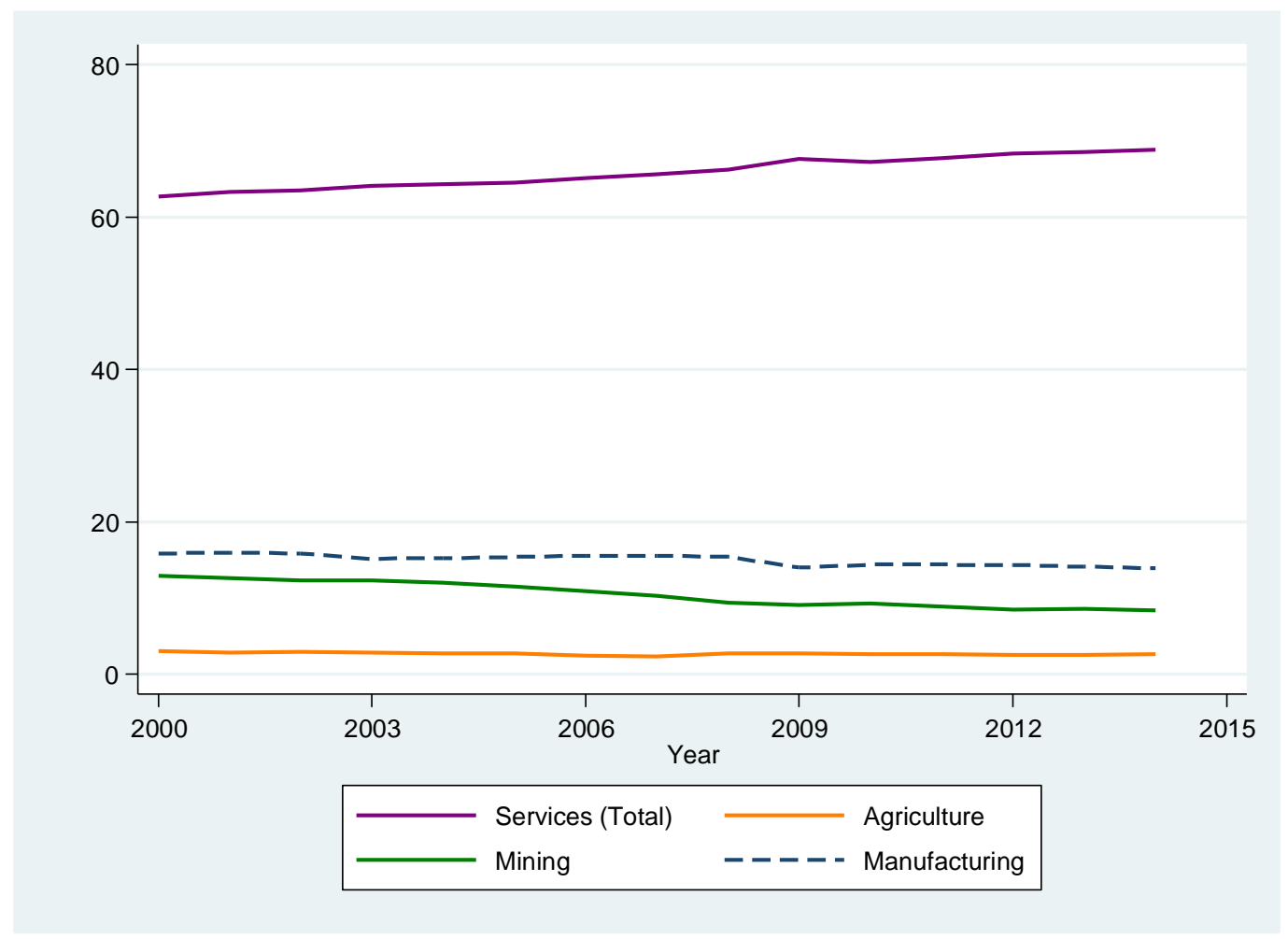

Source: Authors' calculations from Quantec (2016).

Indeed, the services sector has grown from comprising approximately 61 per cent of GDP in 2000 to 65 per cent of GDP in 2014. In contrast, manufacturing and mining have both experienced steady declines in their share of GDP, while agriculture's contribution to GDP has remained low and stable. The data would thus suggest, fairly strongly, that in level terms alone, South Africa can be characterized as a services-orientated economy.

Disaggregating the services sector into sub-sectors provides further insight into service industry contributions to GDP. Figure 2 breaks the services sector down into its various sub-sectors, or industries, and compares their GDP shares to that of manufacturing over time. Two of the main service sector contributors to GDP are traditional service industries, namely, government services, and wholesale and retail trade. Government services comprises the highest share of GDP across all industries and was only surpassed by manufacturing briefly in the period from 2006 to 2007. Wholesale and retail trade has surpassed manufacturing as the second largest contributor to GDP over the period. 
Figure 2: Manufacturing and service industries' contribution to GDP, 2000-14

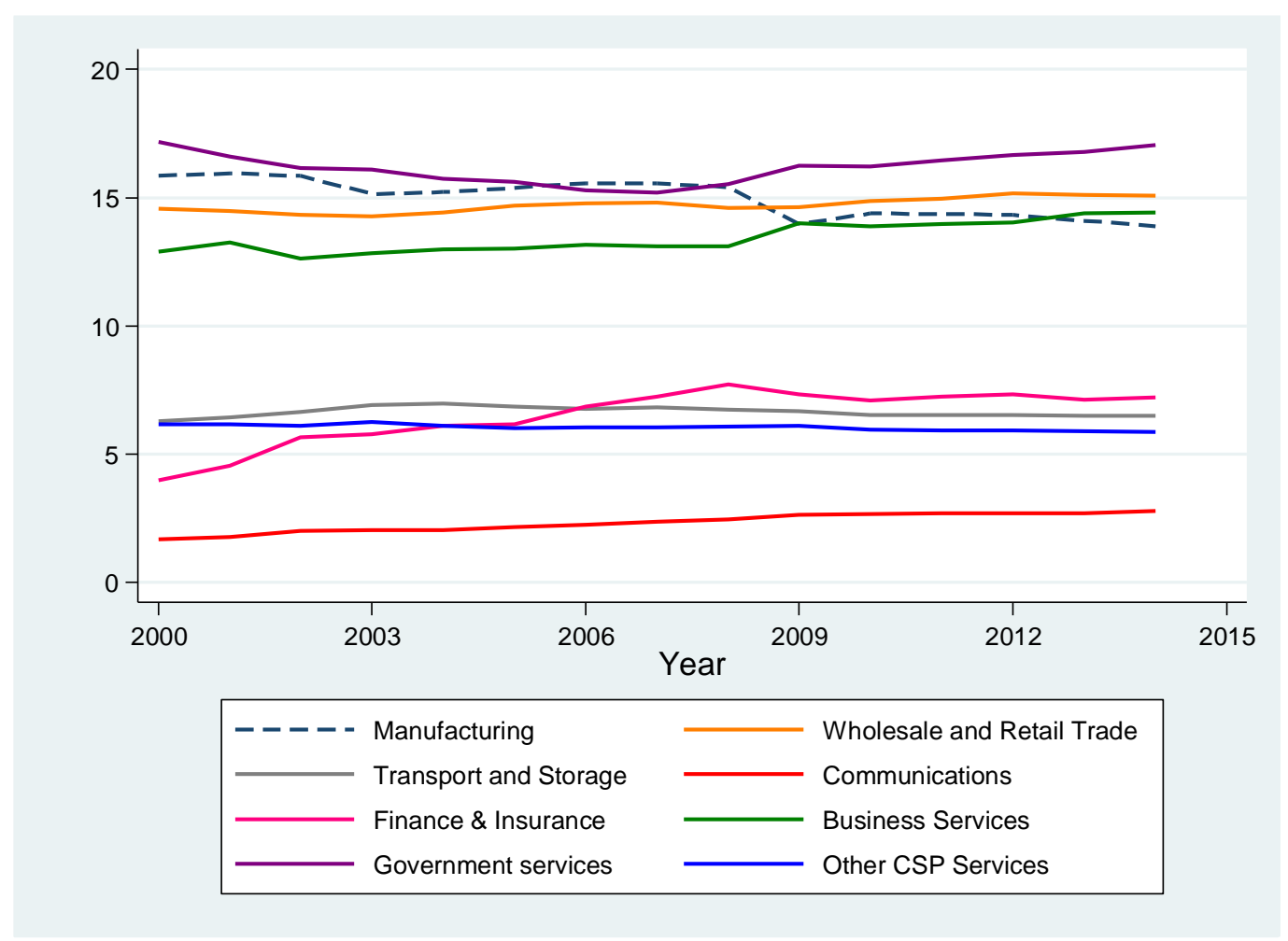

Source: Authors' calculations from Quantec (2016).

The share of GDP comprised of more modern service industries, such as business services, financial and insurance services, and communication, has in turn increased across all three industries, with growth most rapid in the financial and insurance services industry. Financial and insurance services comprised a smaller share of GDP than other CSP services and transport and storage services in 2000, but superseded these traditional service industries by 2014 . As an aggregate, modern service industries have increased their share of GDP from approximately 19 per cent in 2000 to 25 per cent in 2010.

Ultimately then, the steady decline in the share of GDP accounted for by manufacturing, mining, and agriculture, together with the steady rise in the share of the services sector, re-asserts the notion that the South African economy is not only services-based, but has becomes increasingly so over the last 15 years.

\section{Employment}

The services sector's substantial contribution to GDP is matched by its contribution to employment. It is evident in Table 1 that in 2000, the tertiary sector accounted for 65 per cent of total employment. This rose to 74 per cent in 2014. The sector as a whole is responsible for 119 per cent of employment growth over the period, thus counteracting employment losses in manufacturing and agriculture. The services sector has accounted for almost all of South Africa's employment growth since 2000 . Hence, while the primary sector experienced a decline in total employment and secondary sector employment grew by 126,734 jobs, employment in the tertiary sector rose by over 3 million jobs.

The performance of the services sub-sectors with respect to absolute and relative growth in employment, as well as changes in employment shares, provides further insight into the sector's 
substantial contribution to employment growth. For instance, wholesale and retail trade, business services, government services, and other CSP services are the largest sources of employment in 2014 (see column 5). These four sub-sectors were the largest contributors to changes in employment over the period (see column 6). Employment shares for service industries have risen or remained constant in all cases other than in catering and accommodation (see columns 4 and 5). Business services displayed the strongest growth relative to other sub-sectors in the economy, followed by transport and storage, and government services (see column 3 of Table 1). In level terms, the major job generator across all the industries in the South African economy, has been wholesale and retail trade ( 943,619 jobs), followed by the public sector (government services grew by 632,811 jobs).

Table 1: Total employment by industry

\begin{tabular}{|c|c|c|c|c|c|}
\hline & \multicolumn{2}{|c|}{ Growth (2000-14) } & \multicolumn{2}{|c|}{$\begin{array}{l}\text { Employment } \\
\text { shares }\end{array}$} & \multirow{2}{*}{$\begin{array}{l}\text { Share of change } \\
\left(\Delta \mathrm{E}_{\mathrm{j}} / \Delta \mathrm{E}\right) \\
(2000-14)\end{array}$} \\
\hline & Absolute & $\begin{array}{l}\text { Relative } \\
\left(\% \Delta \mathrm{E}_{\mathrm{j}} / \% \Delta \mathrm{E}\right)\end{array}$ & 2000 & 2014 & \\
\hline Primary & -625986 & $-1,57$ & 0,15 & 0,09 & $-0,24$ \\
\hline Agriculture & -704991 & $-2,25$ & 0,12 & 0,05 & $-0,27$ \\
\hline Mining & 79005 & 0,92 & 0,03 & 0,03 & 0,03 \\
\hline Secondary & 126734 & 0,25 & 0,20 & 0,17 & 0,05 \\
\hline Manufacturing & -206168 & $-0,64$ & 0,12 & 0,09 & $-0,08$ \\
\hline Utilities & 14944 & 1,48 & 0,004 & 0,004 & 0,01 \\
\hline Construction & 317959 & 1,79 & 0,07 & 0,08 & 0,12 \\
\hline Tertiary & 3082466 & 1,84 & 0,65 & 0,74 & 1,19 \\
\hline Catering \& accommodation & -34630 & $-0,47$ & 0,03 & 0,02 & $-0,01$ \\
\hline Wholesale and retail trade & 943619 & 1,92 & 0,19 & 0,22 & 0,37 \\
\hline Transport \& storage & 231051 & 2,63 & 0,03 & 0,04 & 0,09 \\
\hline Communications & 13598 & 0,46 & 0,01 & 0,01 & 0,01 \\
\hline Finance \& insurance & 31359 & 0,41 & 0,03 & 0,03 & 0,01 \\
\hline Business services & 729272 & 3,08 & 0,09 & 0,12 & 0,28 \\
\hline Other CSP & 535386 & 1,39 & 0,15 & 0,16 & 0,21 \\
\hline Government services & 632811 & 2,14 & 0,11 & 0,14 & 0,24 \\
\hline Total & 2583214 & 1,00 & 1,00 & 1,00 & 1,00 \\
\hline
\end{tabular}

Source: Authors' calculations from Quantec (2016).

The strong employment growth in the business services sector needs to be tempered by the fact that a large share of employment in this sector is in temporary employment services (TES). ${ }^{4}$ TES employment refers to the practice of third-party companies providing workers to perform occupations such as cleaning, accounting, or security services, to formal sector firms (Bhorat et al. 2015). Thus, formal sector firms are outsourcing certain occupations and do not directly hire

\footnotetext{
${ }^{4}$ Bhorat, Cassim et al. (2014) argue that the 'business not elsewhere classified' sub-industry is dominated by TES companies and therefore can be used as an approximation of the TES industry as a whole. To support this claim, they show that the three main occupational categories in the business NEC sub-sector were 'protective service workers not elsewhere classified', 'helpers and cleaners', and 'farmhands and labourers'. All three occupations would be regarded as belonging in the TES category. Evidently, not all business NEC workers fall into the TES category, which suggests our approximation might be an over-estimate. However, it must also be noted that not all TES workers would classify themselves under this category. For example, workers employed by a labour broker to work in mining or construction are likely to respond that they work in mining or construction, rather than in the businesses sector. As a result, this might lead to an actual underestimate of the total number of TES workers.
} 
these workers. Bhorat et al. (2015) found that TES employment as a percentage of business services employment has risen dramatically in the post-apartheid period. They estimate that approximately 61 per cent of business services employees were in TES employment in 2014. The rise in labour brokering agencies in South Africa is usually attributed to the burdensome regulatory environment governing labour relations, in particular around the cost of hiring and firing workers. TES employment effectively allows firms to pass off these potential regulatory costs to specialized employment services firms.

The sizeable expansion of the wholesale and retail trade industry needs to be considered in relation to the high levels of informality associated with the industry (Cassim et al. 2016). The forced segregation policies of apartheid resulted in the development of large informal settlements, where vibrant retail markets developed. Estimates suggest that in 2003 informal retail outlets in townships accounted for 10 per cent of total retail trade in South Africa (Ligthelm 2008). In Figure 3, we look at the ratio of informal sector employment in manufacturing relative to informal sector employment in four services sub-sectors. ${ }^{5}$ It is evident that the share of informality, relative to manufacturing, is highest in the trade sub-sector (wholesale and retail trade, and accommodation and catering services). ${ }^{6}$

Figure 3: Informal sector employment relative to manufacturing

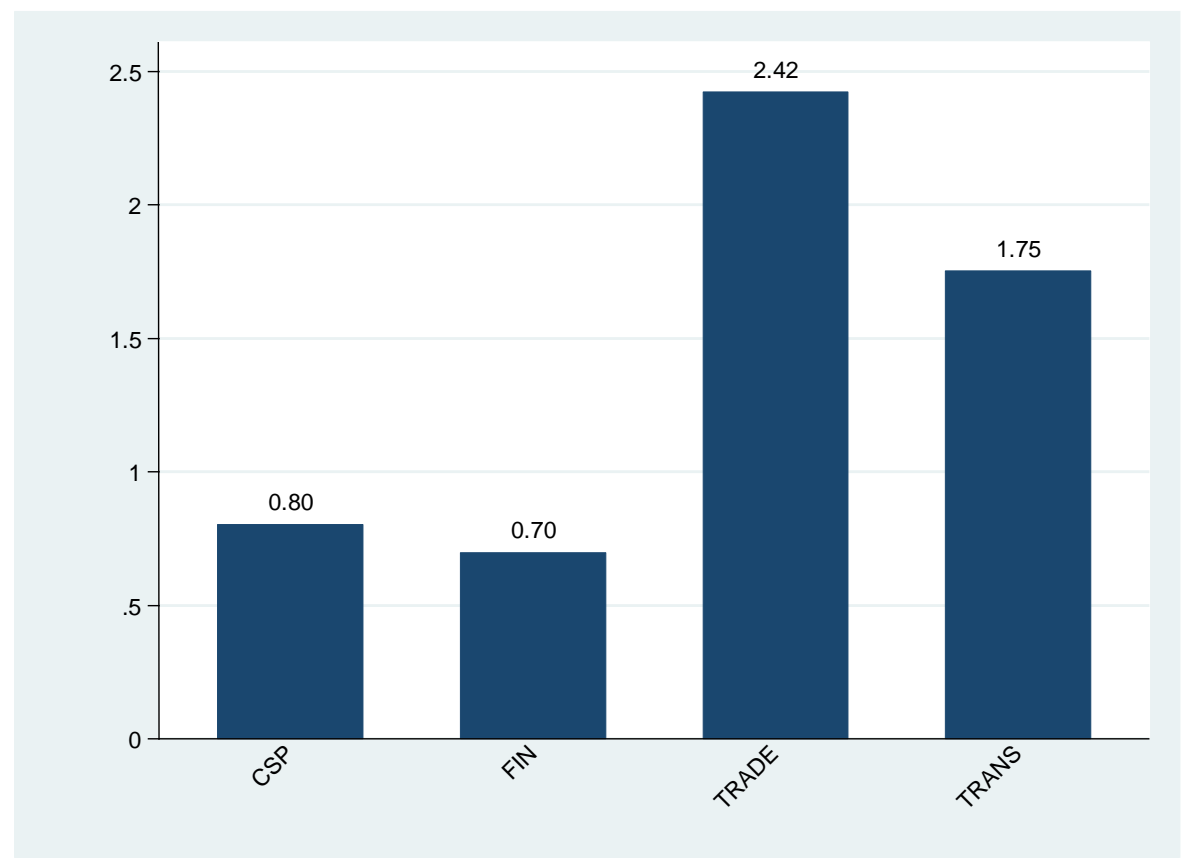

Note: Informality defined using registration of enterprise definition. CSP = government services and other CSP services; FIN = business services and financial and insurance; TRADE = catering and accommodation and wholesale and retail trade services; TRANS $=$ communications and transport and storage.

Source: Authors' calculations based on LMDS (Statistics South Africa 2014).

Government services accounts for the third largest absolute contribution to employment growth over the period 2000 to 2014. This largely reflects growth in employment in national, provincial, and local government structures. Bhorat et al. (2015) suggest that this job creation may be concentrated in unskilled and medium-skilled occupations, in part, although not exclusively,

\footnotetext{
${ }^{5}$ We define the informal sector using the registration of enterprise definition.

${ }^{6}$ Estimates derived from the Labour Market Dynamics Survey from Statistics South Africa (2014), show that approximately 41 per cent of employment in wholesale and retail trade services is informal sector employment.
} 
relating to infrastructure building and public safety. It is questionable whether this is sustainable, as it puts significant strain on the government's wage bill, thus having both an adverse effect on the fiscal budget as well as diverting resources away from other projects.

In contrast to the services sector as a whole, manufacturing and agriculture account for a relatively small and declining share of employment. Over the 14-year period, close to a quarter of a million manufacturing jobs were shed. This is consistent with the lack of dynamism and competitiveness in the manufacturing sector (Bhorat et al. 2015). Manufacturing has thus been ineffective as a large-scale generator of jobs and it would thus appear that the services sector has replaced this uncompetitive secondary sector as the economy's key source of net new jobs.

Agriculture experienced the largest decline in employment, with a loss of over 700,000 jobs. One possible explanation for these job losses is the introduction of an agriculture sector minimum wage in 2003. Bhorat, Kanbur et al. (2014) analyse the impact of this legislation and find evidence of significant disemployment effects.

Small gains in employment were made in mining, utilities, and construction. The commodities boom in the early 2000s, due to rising demand from emerging markets such as China, led to gains in mining employment (Bhorat et al. 2015). However, the sharp down-turn of prices in 2008 and 2009 due to the credit crunch may have dampened this effect. Furthermore, the weak performance of the Rand in the mid-2000s, energy and infrastructural constraints (e.g. rail transportation), the introduction of new mining laws, and strike action in 2010 and 2011 are likely to have exacerbated slow employment growth in the sector (Bhorat et al. 2015).

The above then ultimately suggests that the historical importance of the primary sectors (namely agriculture and mining) has significantly waned in the post-apartheid South African economy. In addition, the poor output and employment performance of the manufacturing sector is manifest in the steady decline, bordering on de-industrialization, for the domestic economy. The upshot of the latter two trends has been a rapid growth in the job-generating capacity of the services economy. This services employment growth in turn can be understood within the context of several underlying trends: Firstly, in the pursuit of regulatory avoidance, formal firms have increased the use of temporary employment services-thus increasing the share of workers categorized as 'business service' employees. Secondly, South Africa's consumption-driven economic growth model has resulted in a rapid rise in the growth of retail employment. Thirdly, the poor employment generating capacity of the formal sector as a whole has witnessed a rapid rise in the number of individuals working in various informal services sectors. Finally, in constituting close to a quarter of all new jobs generated in South Africa since 2000, the public sector has become possibly the key generator of jobs in the economy-ensuring that much of the country's first-order services employment is shaped by national and provincial government hiring practices.

\section{Productivity}

Structural transformation involves the shift of resources from low-productivity activities toward high-productivity activities. Using a method of analysis in line with that applied by McMillan et al. (2014), we examine the extent to which services has played a role in structural transformation in South Africa over the period 1970 to 2014. Figure 4 shows the correlation between the natural $\log$ of relative labour productivity and the change in employment by industry. The marker size for each industry represents the industry's share of employment in 2014. The linear regression line indicates whether the structural transformation has been growth inducing (positively sloped) or not (negatively sloped). Given that structural transformation is the shift of resources from low-productivity activities toward high-productivity activities, one would 
ideally want to see declining employment shares in low-productivity industries (bottom left quadrant) and rising employment in high-productivity industries (top right quadrant).

The positively sloped linear regression line suggests growth-inducing structural transformation. There is therefore a shift in employment away from relatively low-productivity industries, such as agriculture, and catering and accommodation, toward higher-productivity activities in business services, transportation services, and government services. However, the growth-inducing effect of this structural transformation is tempered by the fact that the slope of the regression line is only slightly positive, and perhaps unsurprisingly, the estimated coefficient of the slope is not statistically significant.

Based on Figure 4, one could argue that the structural transformation that has taken place has been service-led rather than manufacturing-led. Hence, it is evident that there has been a decline in the employment share of low-productivity industries, such as agriculture, and catering and accommodation services (bottom left quadrant). Structural transformation following the East Asian model would depict manufacturing in the top right quadrant-i.e. growing employment in a high-productivity industry. In South Africa's case, manufacturing appears in the top left quadrant, suggesting a shift of resources (labour) away from this high-productivity industry. Nevertheless, the manufacturing industry is still a key employer (see Table 1) in the domestic economy. One does observe that there has been a shift of resources toward relatively highproductivity industries in the services sector, in particular transportation services, business services, and government services. This does point to service-led structural transformation over the period from 2000 to 2014.

Figure 4: Correlation between sectoral productivity and change in employment shares in South Africa, 2000-14

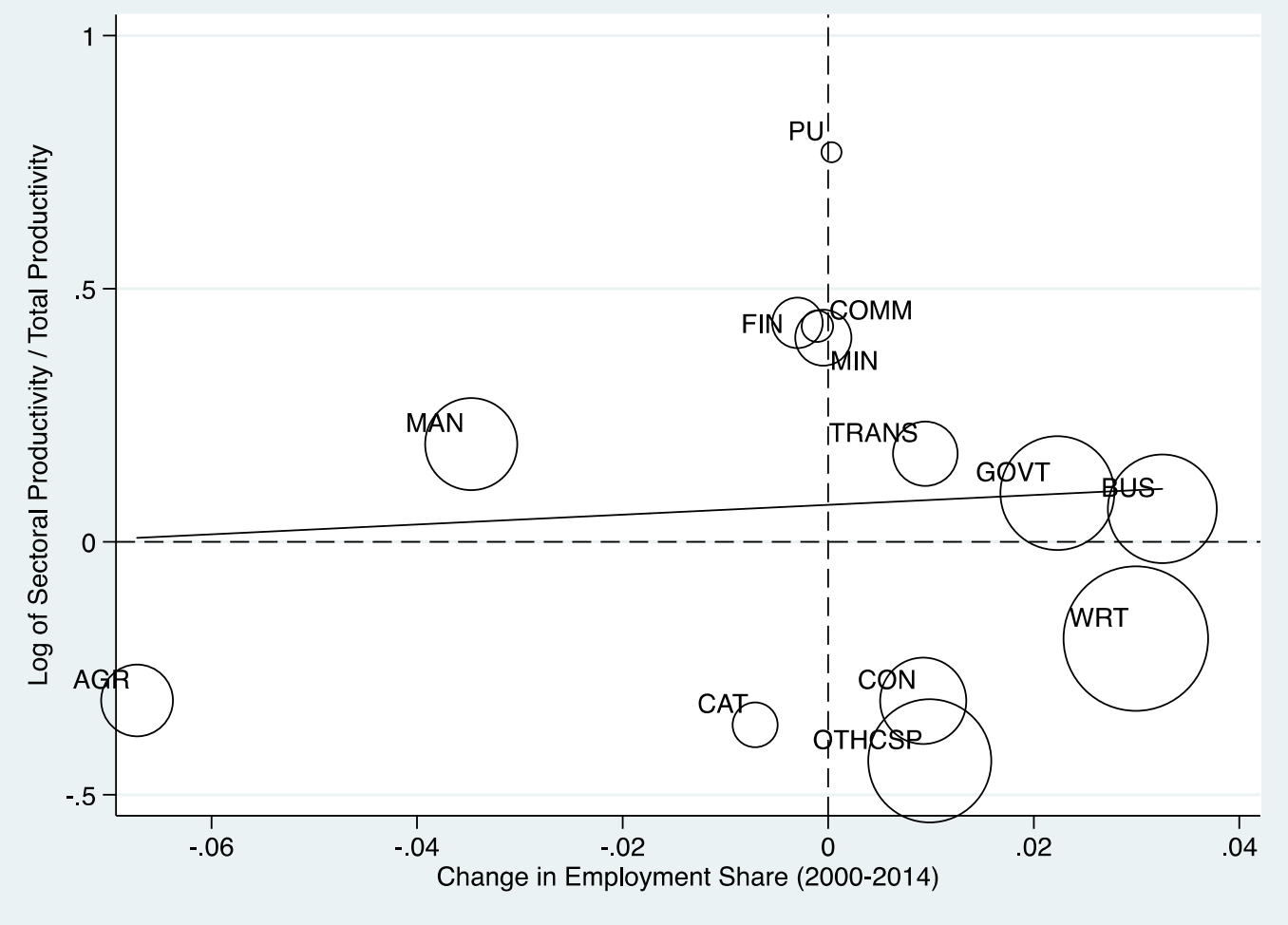

Notes: 1. Size of circles represents employment shares in 2014. 2. Coefficient of fitted is 0.97 (t-stat 0.23 , p-value 0.82). 3. $A G R=$ agriculture; $M I N=$ mining; $M A N=$ manufacturing; $P U=$ utilities; $C O N=$ construction; $C A T=$ catering and accommodation; WRT = wholesale and retail trade; TRANS = transport and storage; $\mathrm{COMM}=$ communication; FIN = finance and insurance; BUS = business services; OTHCSP = other community, social, and personal services; GOV = government services.

Source: Authors' calculations based on Quantec (2016). 
In addition to a shift of labour resources away from manufacturing, there is also a shift of these resources away from relatively high-productivity mining, communications, and finance and insurance service industries. Mining job destruction is consistent with the long-term trend of a declining mining sector, falling commodity prices, and increased capital intensity in mining production.

We also see a shift of labour resources toward the relatively low-productivity wholesale and retail trade industry, which now comprises a substantial share of employment in South Africa. As mentioned above, the concern with growth in the wholesale and retail trade industry, as expressed by McMillan et al. (2014) regarding structural transformation in Africa and Latin America, is that a large share of it may be in low-productivity informal sector activities.

There are also some cautionary tales regarding this services-led structural transformation. Firstly, it is evident that government services is a large and growing employer in South Africa. The economic sustainability of an expanding public sector is cause for concern. It is questionable whether sustained long-term economic growth and development can be achieved via a growing public sector. Secondly, and as discussed in more detail above, the positive aspects of growth in the relatively high-productivity business services industry needs to be tempered by the fact that a large share of the employment in this sector is in TES. Therefore, one does need to question whether growth in the South African economy is being driven by a high-productivity services sector. The above-mentioned points suggest not.

As in McMillan et al. (2014), we decompose South Africa's productivity growth. Productivity growth can be realized along two dimensions: Firstly, growth can occur within economic sectors through capital accumulation or technological change. Secondly, growth can occur as labour moves across sectors from low-productivity activities to high-productivity activities. The estimates from the decomposition are depicted in Figure 5. The decomposition of South Africa's productivity growth over the period from 2000 to 2014 indicates that productivity growth within sectors grew by 1.7 per cent per annum, while productivity growth across sectors grew by 0.06 per cent per annum. Therefore, 97 per cent of the growth of productivity in South Africa took place within sectors. 
Figure 5: Decomposition of productivity for South Africa, 2000-14

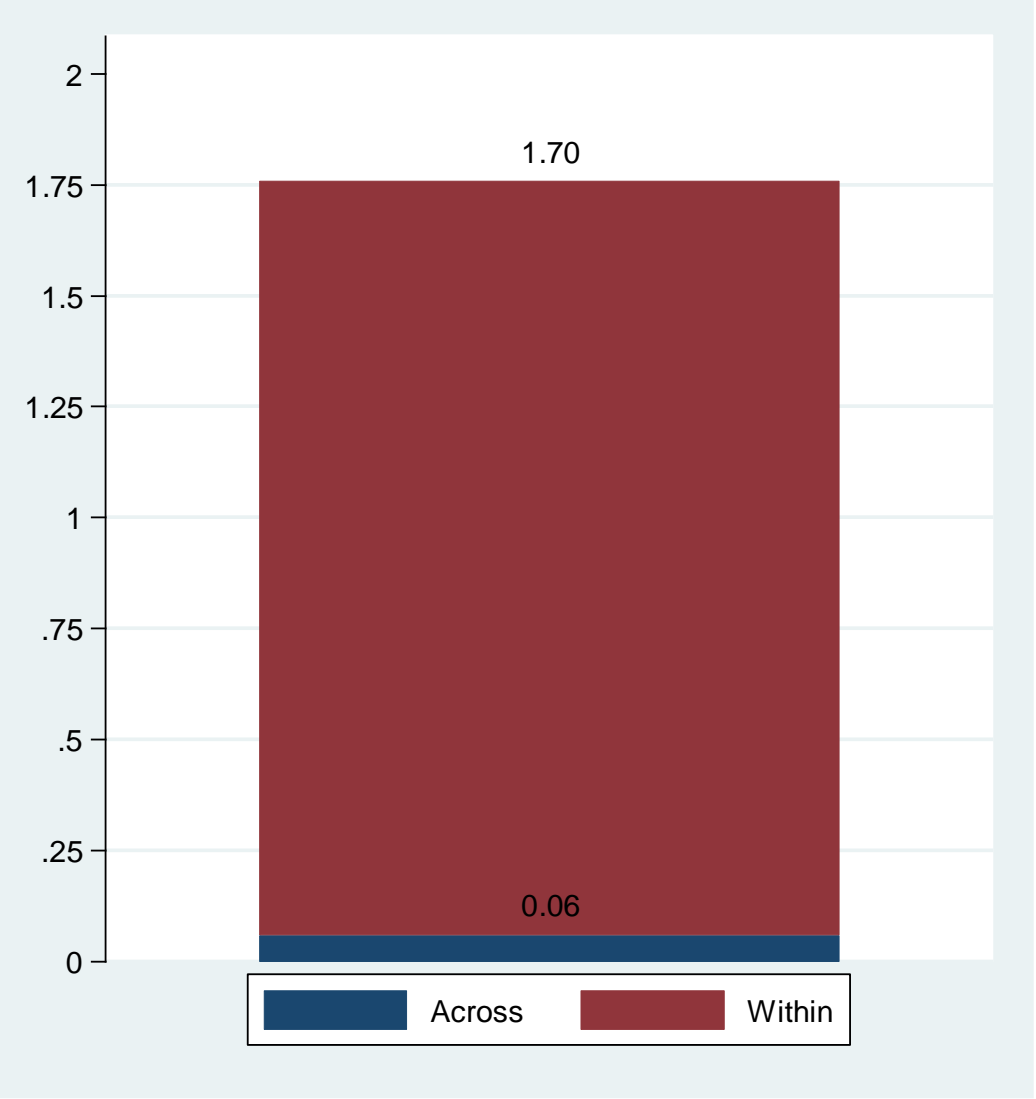

Source: Authors' calculations based on Quantec (2016).

The dominance of within-sector productivity growth may be explained by the following: firstly, it may be the case that to some extent productivity growth within industries is being driven by the shifting of labour away from low-productivity firms toward high-productivity firms. Such a pattern could occur within both high- and low-productivity sectors. Secondly, it may be the case that firms are adjusting production processes by becoming more capital- and technologyintensive. ${ }^{7}$ The result of which would be increased unemployment.

\subsection{Labour market characteristics of the services sector}

In the following section, we examine the services sector in greater detail. We look at the demographic characteristics, skill levels, and wages associated with this sector.

\section{Employment profile}

Table 2 shows some of the key characteristics of workers who are employed in the manufacturing and service industries. The sample is restricted to employees only.

The gender profile of the various industries, suggests that manufacturing, transport and storage, government services, communication, and business services are male-dominated sectors. In

\footnotetext{
${ }^{7}$ A number of studies focusing on structural change in South Africa show that within-sector shifts were driven by technological change and relatedly increased capital-intensity of production, which in turn has impacted on labour demand (Bhorat and Hodge 1999; Edwards 2001; Edwards and Lawrence 2008).
} 
contrast, the accommodation and catering, other CSP services, and financial services industries are female-dominated. In wholesale and retail trade, males are marginally more prominent than females.

By racial composition, the large majority of workers are African. Africans comprise over 60 per cent of each sector, with the exception of the financial services industry, where they make up 49 per cent of the industry, reflecting to some extent the existence of high-skilled jobs in financial services where white employees are more dominant. In four industriesaccommodation and catering, transport and storage, government services, and other CSP services-Africans constitute over 70 per cent of the workers. Coloured workers are evenly spread across all industries. They are most prominent in the manufacturing (16.5 per cent) and communications (14.2 per cent) industries. Indian employees are most common in the communications (8.1 per cent) and financial services (7.4 per cent), and least prominent in the government services (2.0 per cent) and other CSP services (2.7 per cent). As with Indian employees, the biggest industries for white workers are communications (20.9 per cent) and financial services (30.1 per cent). They are also the second-biggest racial group in business services (19.7 per cent) after Africans. These three sectors, as we show below, also yield a high proportion of highly skilled individuals.

In terms of age, there is a higher-than-average youth cohort (15-24) in the wholesale and retail trade (15.6 per cent) and accommodation and catering (18.7 per cent) industries. The $25-34$ age cohort is evenly spread, although they have lower-than-average representation in the government services and other CSP services industries. In contrast, the 35-44 cohort has the highest proportion of workers in government services $(37.0$ per cent), followed by business services (29.2 per cent), and communication (32.3 per cent). 
Table 2: Characteristics of the employed by industry, 2014

\begin{tabular}{|c|c|c|c|c|c|c|c|c|c|}
\hline & Manufacturing & $\begin{array}{l}\text { Wholesale } \\
\text { and retail } \\
\text { trade }\end{array}$ & $\begin{array}{l}\text { Catering \& } \\
\text { accommodation } \\
\text { services }\end{array}$ & $\begin{array}{l}\text { Transport } \\
\text { \& storage }\end{array}$ & $\begin{array}{l}\text { Government } \\
\text { services }\end{array}$ & $\begin{array}{l}\text { Other CSP } \\
\text { services }\end{array}$ & Communication & Financial services & Busliness services \\
\hline $\begin{array}{l}\text { Gender } \\
\text { Male } \\
\text { Female }\end{array}$ & $\begin{array}{l}70.0 \\
30.0\end{array}$ & $\begin{array}{l}55.8 \\
44.2\end{array}$ & $\begin{array}{l}38.2 \\
61.8\end{array}$ & $\begin{array}{l}82.9 \\
17.1\end{array}$ & $\begin{array}{l}59.3 \\
40.7\end{array}$ & $\begin{array}{l}31.9 \\
68.1\end{array}$ & $\begin{array}{l}67.3 \\
32.7\end{array}$ & $\begin{array}{l}43.9 \\
56.1\end{array}$ & $\begin{array}{l}59.9 \\
40.1\end{array}$ \\
\hline $\begin{array}{l}\text { Race } \\
\text { African } \\
\text { Coloured } \\
\text { Indian } \\
\text { White }\end{array}$ & $\begin{array}{l}63.8 \\
16.5 \\
5.2 \\
14.5\end{array}$ & $\begin{array}{l}67.0 \\
12.9 \\
5.4 \\
14.7\end{array}$ & $\begin{array}{l}79.4 \\
9.9 \\
2.4 \\
8.3\end{array}$ & $\begin{array}{l}77.1 \\
9.2 \\
3.4 \\
10.2\end{array}$ & $\begin{array}{l}78.0 \\
10.7 \\
2.0 \\
9.4\end{array}$ & $\begin{array}{l}74.3 \\
10.0 \\
2.7 \\
13.0\end{array}$ & $\begin{array}{l}56.8 \\
14.2 \\
8.1 \\
20.9\end{array}$ & $\begin{array}{l}50.2 \\
12.2 \\
7.4 \\
30.1\end{array}$ & $\begin{array}{l}44.3 \\
11.7 \\
7.5 \\
36.5\end{array}$ \\
\hline $\begin{array}{l}\text { Age } \\
15-24 \\
25-34 \\
35-44 \\
45-54 \\
55-64 \\
65+ \\
\end{array}$ & $\begin{array}{l}8.8 \\
32.2 \\
32.1 \\
19.1 \\
7.4 \\
0.5 \\
\end{array}$ & $\begin{array}{l}15.6 \\
38.4 \\
25.8 \\
13.6 \\
6.0 \\
0.6 \\
\end{array}$ & $\begin{array}{l}18.7 \\
38.6 \\
27.9 \\
11.0 \\
3.6 \\
0.2\end{array}$ & $\begin{array}{l}8.4 \\
35.9 \\
30.6 \\
15.5 \\
9.4 \\
0.3 \\
\end{array}$ & $\begin{array}{l}3.1 \\
28.5 \\
37.0 \\
22.4 \\
8.8 \\
0.2 \\
\end{array}$ & $\begin{array}{l}6.0 \\
25.1 \\
31.7 \\
24.8 \\
11.4 \\
1.0 \\
\end{array}$ & $\begin{array}{l}7.7 \\
32.6 \\
32.3 \\
19.4 \\
7.7 \\
0.3 \\
\end{array}$ & $\begin{array}{l}10.0 \\
36.9 \\
27.5 \\
16.6 \\
7.6 \\
1.4\end{array}$ & $\begin{array}{l}9.0 \\
37.7 \\
29.2 \\
16.5 \\
6.4 \\
1.3\end{array}$ \\
\hline $\begin{array}{l}\text { Education Level } \\
\text { No education } \\
\text { Primary } \\
\text { Incomplete secondary } \\
\text { Secondary } \\
\text { Tertiary } \\
\text { Unspecified }\end{array}$ & $\begin{array}{l}0.9 \\
7.7 \\
37.9 \\
45.1 \\
7.6 \\
0.9\end{array}$ & $\begin{array}{l}1.0 \\
6.0 \\
35.0 \\
52.6 \\
4.1 \\
1.3\end{array}$ & $\begin{array}{l}1.1 \\
6.4 \\
37.0 \\
52.2 \\
2.0 \\
1.4\end{array}$ & $\begin{array}{l}1.0 \\
8.6 \\
38.4 \\
44.6 \\
6.2 \\
1.2\end{array}$ & $\begin{array}{l}0.8 \\
4.5 \\
14.9 \\
63.9 \\
15.4 \\
0.5\end{array}$ & \begin{tabular}{l|}
1.5 \\
6.3 \\
23.1 \\
45.5 \\
22.8 \\
0.7
\end{tabular} & $\begin{array}{l}0.0 \\
2.9 \\
19.4 \\
63.0 \\
14.4 \\
0.3\end{array}$ & $\begin{array}{l}0.1 \\
2.7 \\
10.8 \\
65.3 \\
20.6 \\
0.4\end{array}$ & $\begin{array}{l}0.5 \\
1.2 \\
16.2 \\
51.0 \\
30.3 \\
0.8\end{array}$ \\
\hline
\end{tabular}

Source: Statistics South Africa (2014). 
In terms of educational attainment, the vast majority of workers have either an incomplete secondary or secondary (i.e. passed grade 12) education. In all sectors, the proportion of workers who have completed secondary school outnumber those who attended secondary school but did not complete it. The proportion of workers who have a tertiary education is highest in other CSP services (22.8 per cent) and financial services (22.5 per cent). As we shall see in the next section, these two sectors also have the highest proportion of highly skilled workers, indicating a close relationship between educational attainment and skill level.

We now turn our attention to examining key demographics in relation to the manufacturing sector. This is important as it allows us to compare easily the differences between the manufacturing sector and the various services sectors.

In Figure 6 below, we compare the proportion of females and youth (15-24 years old) in the different services sectors to the proportion of females and youths in the manufacturing sector in order to obtain a ratio. A ratio of less than unity indicates there is a greater proportion of females/youths in manufacturing relative to the other industry. A ratio of greater than unity indicates there is a greater proportion of females/youths in a services industry as compared to the manufacturing industry.

Figure 6: Services industry female and youth ratio relative to manufacturing

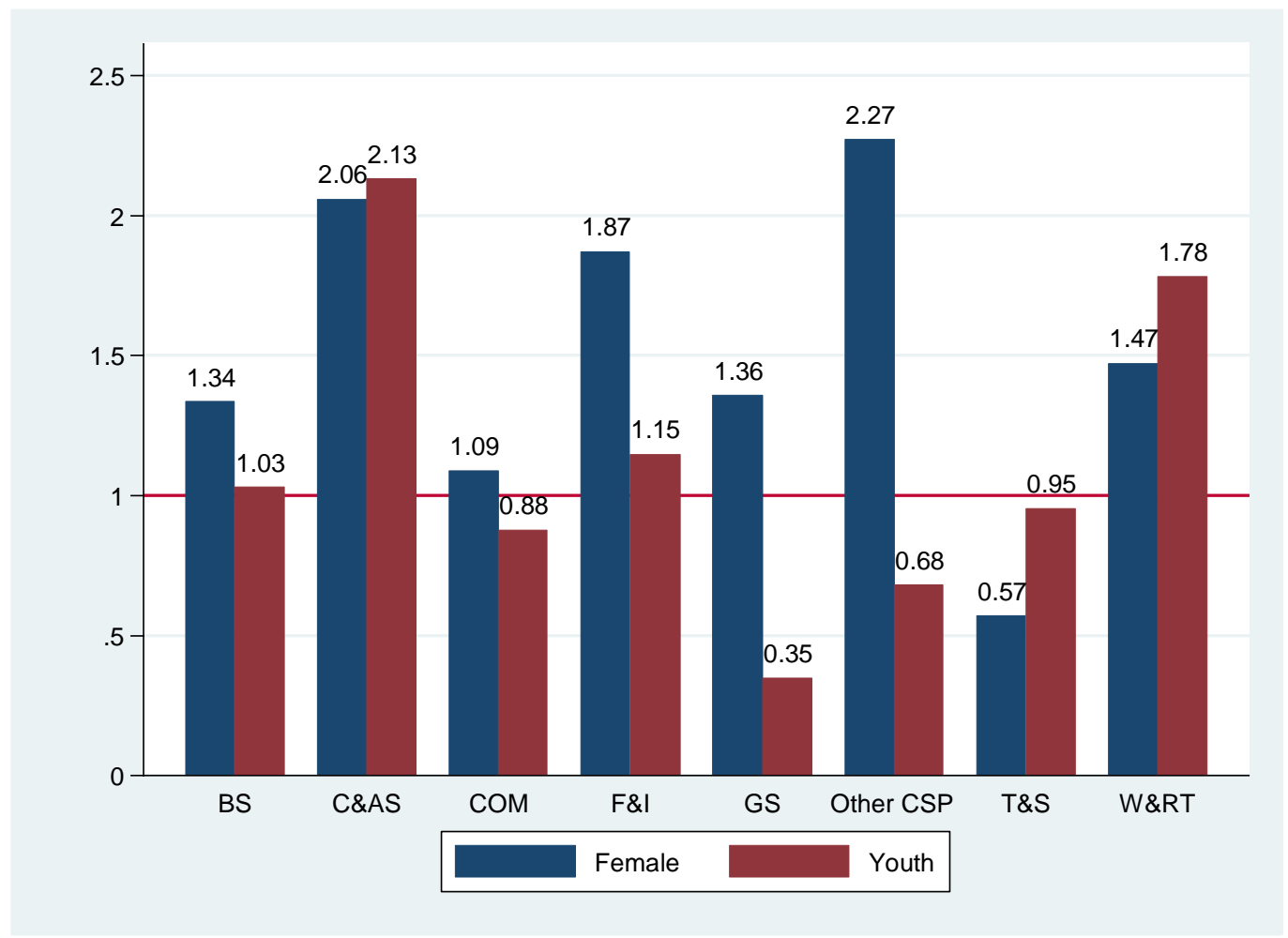

Notes: $\mathrm{BS}$ = business services; $\mathrm{C} \& A S=$ catering and accommodation services; $\mathrm{COM}=$ communications; $\mathrm{F} \& \mathrm{I}=$ financial and insurance; GS = government services; Other CSP = other CSP services; T\&S = transport and storage; $W \& R T=$ wholesale and retail trade.

Source: Authors' calculations based on Statistics South Africa (2014).

Of the services industries considered, only transport and storage (0.57) has a lower proportion of females than manufacturing. Business services, government services, and wholesale and retail trade have a moderately higher proportion of females than manufacturing. Finance and insurance, catering and accommodation, and other CSP services have more than double the 
proportion of females relative to manufacturing. Therefore, and consistent with much of the global literature, the various service industries in our sample for South Africa are more intensive in the use of female relative to male workers-when compared with the manufacturing sector.

In addition, the services industries remain largely biased toward older workers, relative to manufacturing. Of the eight service industries considered, five have a ratio of less than one. Notably, government services has a ratio of 0.35 , which is far below that of the next lowest sector-other CSP services (0.68). This low ratio could possibly be explained by either young people not being interested in obtaining a job in government, or a job in government usually requiring some sort of post-secondary qualification.

Interestingly, finance and insurance has a higher youth ratio than manufacturing, despite jobs in this sector usually requiring a tertiary qualification. It is not surprising to see a higher-thanaverage youth ratio in wholesale and retail trade, and catering and accommodation services, as these industries have lower entry barriers in terms of educational qualifications. Furthermore, many young people who are studying for a post-secondary qualification work in these industries to finance their studies.

\section{Skill profile}

In addition to understanding the demographic characteristics of manufacturing and services sector workers, it is equally important to understand the skill profile of these industries, as it will allow us to gain a greater insight into which services sector(s) can be identified as future growth drivers for the South African economy.

Figure 7 shows the proportion of unskilled, semi-skilled, and highly skilled workers relative to manufacturing. Focusing on unskilled workers only, we observe all ratios are below one, with the exception of other CSP services. In other words, the large majority of service industries have a lower proportion of unskilled workers than manufacturing. However, the differences are not that significant in wholesale and retail trade, transport and storage, business services, and catering and accommodation services. All these sectors have a ratio of between 0.86 and 0.93 . On the other hand, finance and insurance and communication services have very low ratios of 0.29 and 0.35 , respectively.

In terms of semi-skilled workers, it is evident that there is a greater proportion of semi-skilled workers than low-skilled workers in service-based industries in relation to manufacturing. Other CSP services and finance and insurance are the two industries that have the lowest ratios $(0.52$ and 0.64, respectively). Wholesale and retail trade, transport and storage, and catering and accommodation services have a marginally higher proportion of semi-skilled workers than manufacturing.

The high ratio for skilled workers demonstrates the 'skills bias' in many service-based industries. Particularly prevalent is the communication, government services, business services, and finance and insurance industries, which all have a ratio above or equal to 1.36. This demonstrates the great demand for highly skilled workers in these industries. Furthermore, it is remarkable that catering and accommodation and wholesale and retail trade services have a moderately higher proportion of skilled workers than manufacturing considering that these two sectors have a far higher proportion of youth than manufacturing does. 
Figure 7: Unskilled, semi-skilled, and highly skilled ratio relative to manufacturing

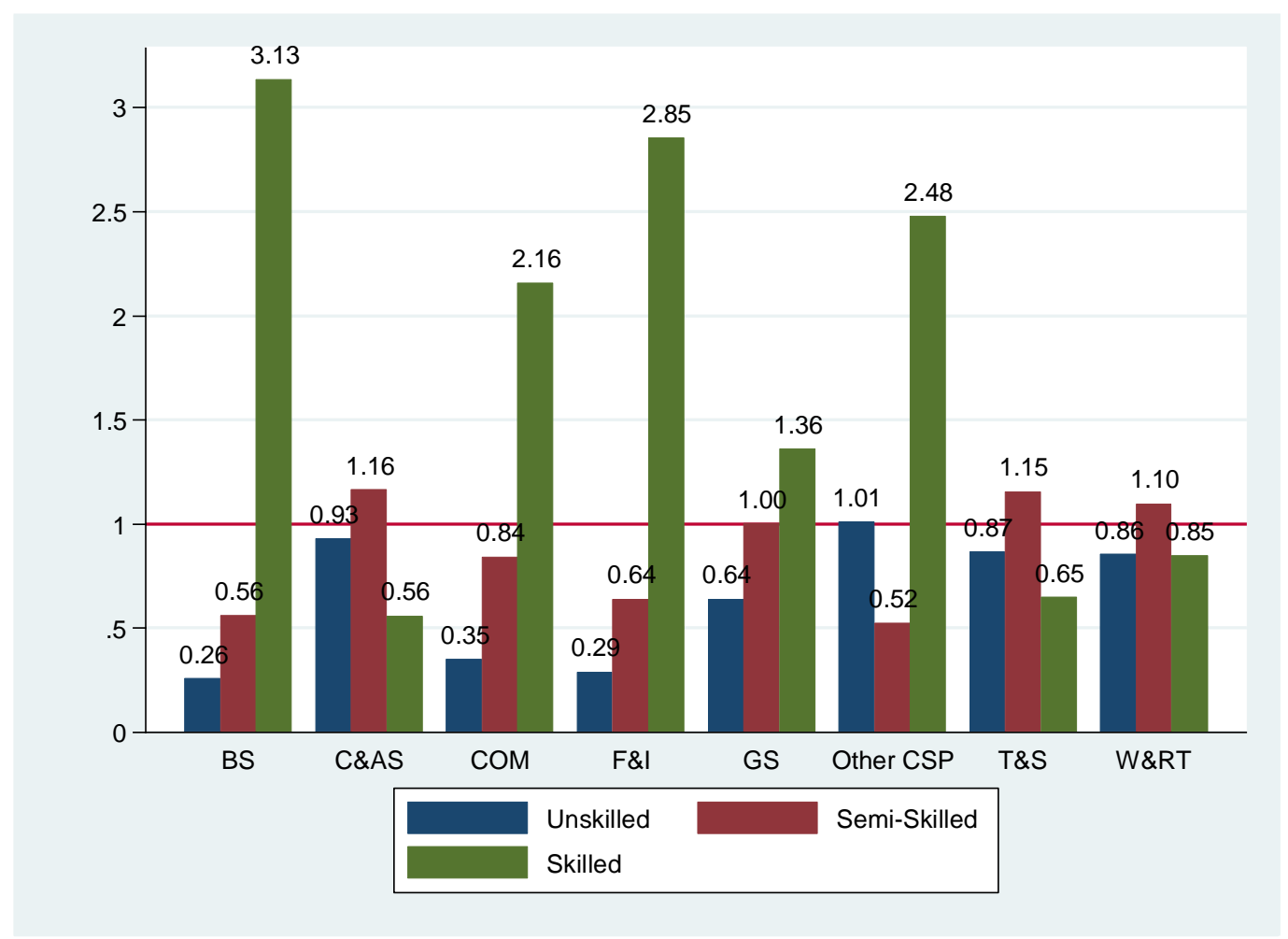

Notes: BS = business service; C\&AS = catering and accommodation services; $C O M=$ communications; F\&I = financial and insurance; GS = government services; other CSP = other CSP services; T\&S = transport and storage; $\mathrm{W} \& \mathrm{RT}=$ wholesale and retail trade.

Source: Authors' calculations based on Statistics South Africa (2014).

The large majority of jobs created in South Africa over the post-2000 period were in business services, government services, and wholesale and retail trade (refer to Table 1). As the government cannot be a sector that can be relied on to produce sustainable economic growth, we restrict our attention to business services and wholesale and retail trade. Overall, we see that business services uses skilled labour more intensely than in manufacturing (certainly for the nonTES component). In addition, the other two modern services industries, communication and finance and insurance, are also skill intensive. Consequentially, for these modern service industries to continue to grow, the proportion of skilled labour must also grow. However, South Africa faces a skills shortage (Rasool and Botha 2011), which suggests growth in these industries is likely to be constrained in the future. The challenge in producing 'good' jobs in the wholesale and retail trade industry is different to the one encountered in the modern services industries. Many of the jobs created in wholesale and retail trade are in the informal sector where skill requirements are low and thus barriers to entry into this industry are low. However, jobs in this sector are also typically low-productivity jobs. Ultimately then, the burden of job generation, which is growth enhancing, falls on the relatively high-skilled and high-productivity segment of the services sector. In the South African context, this can be broadly located within the financial and business services sectors together with communications, and the large formal component of the retail services sector.

Determinants of wages: an econometric approach

We now shift our focus to wage formation in the manufacturing and services sectors. The purpose of estimating an earnings function in our context here is to estimate the conditional 
returns associated with being employed in a particular service sub-sector relative to workers in the manufacturing sector. More importantly, however, the econometric approach enables one to determine and understand the typology of segmentation in the services sector. The analysis in Section 4.1.2 provides initial evidence of segmentation of the services sector as being composed of modern high-productivity services industries, traditional low-productivity services industries, and the public sector. To examine the wage differentials between the manufacturing sector and the various services sub-sectors, we use a standard semi-logarithmic earnings function. Typically, the earnings function is estimated as a Mincerian function for the following specification:

$$
\begin{aligned}
& \text { Log of Monthly } \text { Wages }_{i} \\
& \qquad \begin{aligned}
& \beta_{1}+\beta_{2} X_{i}+\beta_{3}(\text { Wholesale and Retail }) \\
& \left.+\beta_{4} \text { (Catering and Accomodation }\right)+\beta_{5}(\text { Transport and Storage }) \\
& +\beta_{6}(\text { Government Services })+\beta_{7}(\text { Other CSP Services }) \\
& +\beta_{8}(\text { Communications })+\beta_{9}(\text { Finance and Insurance }) \\
& +\beta_{10}(\text { Business Services })+\beta_{11}(\text { TES })+\beta_{12}(\text { Informal Services })+U i
\end{aligned}
\end{aligned}
$$

The dependent variable measuring earnings is the natural $\log$ of an individual's self-reported monthly wage. The explanatory variables of interest include dummies for the ten services subsectors, with the reference variable being a dummy for the manufacturing sector. We introduce two new sub-sectors: firstly, the TES sub-sector, which was previously a sub-set of business services; and secondly, the informal services sub-sector, which comprises all those employed in any of the other nine services sub-sectors but who are employed in the informal sector. ${ }^{8}$ Consequentially, all employees who are in services but not in that group are in the formal sector. The vector $X_{i}$ consists of controls for observable characteristics, such as gender, race, education, age, location, occupation, firm size, experience, union membership, and hours of work. The sample consists of employees who work in the manufacturing sector or in one of the ten services sub-sectors, and earn a positive monthly wage. We estimate the above equation using the Ordinary Least Squares (OLS) estimator. Table 3 provides OLS regression results for the earnings estimates.

Table 3: OLS earning function estimates

\begin{tabular}{ll}
\hline Sector & Coefficient \\
\hline Wholesale \& retail trade & $-4.08^{\star \star *}$ \\
Catering \& accommodation services & $-8.85^{\star \star *}$ \\
Transport \& storage & 0.29 \\
Government services & $17.23^{\star * *}$ \\
Other CSP services & $-2.97^{\star * *}$ \\
Communications & $1.53^{\star * *}$ \\
Finance \& insurance & $2.57^{\star * *}$ \\
Business services & $-0.69^{\star * *}$ \\
TES & $-7.53^{\star \star *}$ \\
Informal services & $-21.65^{\star * *}$ \\
\hline F-Stat & 69598 \\
Adjusted $R^{2}$ & 0.270
\end{tabular}

Notes: 1. Manufacturing is the reference group. 2. The dependent variable is the log of monthly wages. 3. Excludes the top $1 \%$ of earners and those who reported earning R0 per month. 4 . Controls were included for gender, race, education, age, location, occupation, firm size, experience, union membership, and hours of work. 5. ${ }^{* * *}$ Significant at the $1 \%$ level, ${ }^{* *}$ Significant at the $5 \%$ level, * Significant at the $10 \%$ level.

Source: Authors' calculations based on Statistics South Africa (2014).

\footnotetext{
${ }^{8}$ We use the registration of enterprise definition to define informality.
} 
The results suggest that formal sector employees in wholesale and retail trade and catering and accommodation services earn, on average, 4.08 per cent and 8.85 per cent less than manufacturing workers, respectively. Other sectors, which also, on average, earn less than manufacturing are other CSP services (2.97 per cent), TES (7.53 per cent), and informal services (21.65 per cent). There are two features to highlight from these latter results.

Firstly, the negative earnings premia for the services industries mentioned above point to a segment of the services sector that is characterized by low productivity, low skills, and thus low wages. These results are corroborated by the evidence on productivity levels associated with these industries in Section 4.1.3. and evidence on relative skill levels associated with these industries in Section 4.2.2.

Secondly, TES is significantly different from other business services. While formal TES workers earn 7.5 per cent less than manufacturing workers, the coefficient on business services is zero and not statistically significant, suggesting there is no wage differential between business services and manufacturing. The negative wage differential also illustrates why this sector has grown so significantly over the past decade: employers can contract out non-core activities (e.g. cleaning or catering) to outsourcing companies, who do not give their employees benefits typically afforded to permanent employees (e.g. pension or medical aid). As a result, wages paid to outsourcing employees are low and allow companies to spend less on non-core activities than if the same employees were insourced.

Thirdly, the high negative coefficient on 'informal services' is particularly illuminating, as it suggests informality is highly correlated with low-productivity, low-wage jobs, and is thus of course unlikely to serve as a potential source of long-run sustainable growth in South Africa.

Government services has a substantial wage premium (17.23 per cent) over manufacturing. Although government services has a favourable skills profile (see Figure 7) compared to manufacturing, its profile is less favourable when compared to either communications or finance and insurance. Despite this, the wage premium for government services is far above that of communications (1.51 per cent) and finance and insurance (2.33 per cent). Bhorat et al. (2015) find that the public sector wage premium in South Africa is a result of strong public unions, which regularly secure above inflation wage increases for their members.

While the above results are useful and insightful, these earnings estimates represent coefficients at the mean of the wage distribution. While critical, often these mean results can mask the returns to services sector employment across the entire wage distribution, ranging from lowwage to high-wage workers. In the section that follows, we use a quantile regression to examine wage differentials across the income distribution.

\section{Wages: a quantile regression approach}

A quantile regression approach allows for a more detailed assessment of the returns to individual-level earnings at different points along the wage distribution. This approach can be used to determine if the impact of the explanatory variable of interest (in our case here, the sector of employment) is stronger at any particular point of the distribution, while controlling for other additional individual-level factors that influence earnings. While, through OLS estimation, as estimated in the above regression models, we derive a sample mean by minimizing the sum of squared residuals - the sample median can be derived through minimizing the sum of absolute residuals (Koenker and Basset 1978; Koenker and Hallock 2001). If we take a general statement of this approach across all points, or quantiles, in the distribution, we have the estimation for the regression quantile as minimizing the equation: 


$$
\min _{\beta \in \Re^{\kappa}}\left[\sum_{i \in\left\{i: y_{i} \geq X_{i \beta}\right\}} \theta\left|Y_{i}-X_{i} \beta\right|+\sum_{i \in\left\{i: y_{i}<X_{i \beta}\right\}}\left(1-\theta\left|Y_{i}-X_{i} \beta\right|\right)\right]
$$

This then provides the solution for the $10^{\text {th }}, 50^{\text {th }}$, and $90^{\text {th }}$ quantiles, where $\theta<.10, .5$, and $90<1$, allowing for the estimation at any given point in the distribution of the outcome variable. In the above equation, $\mathrm{Y}_{\mathrm{i}}$ is the dependent variable, $X_{i}$ is the $k \times 1$ vector of independent variables, and $\log$ of monthly wages is the coefficient vector (Koenker and Basset 1978).

In a vein similar to the standard OLS estimates above, we consider the difference in returns to wages across the wage distribution for the different services sectors in relation to the manufacturing sector in Table 4 . The variable of interest here provides an estimate of the returns to each category across the $10^{\text {th }}, 50^{\text {th }}$, and $90^{\text {th }}$ percentile of the income distribution. All coefficients are significant at the 1 per cent level. Overall, the results reveal some interesting relationships that are not apparent in the OLS results.

As one might expect, services sub-sectors positioned within the low-productivity and low-skilled segment of the services sector, such as wholesale and retail trade, catering and accommodation, and TES, yield lower wages at the median and higher end of the earnings distribution $\left(50^{\text {th }}\right.$ and $90^{\text {th }}$ percentiles). However, it is also evident that these industries yield higher wages than manufacturing at the $10^{\text {th }}$ percentile. This is indicative of an industry which has relatively high starting salaries (at least compared to manufacturing), but in which there is limited scope to progress in salary terms. These results also support the notion that these industries do not attract many highly or semi-skilled individuals. However, the high $10^{\text {th }}$ percentile relative wage gap is indicative of relatively strong trade unions in the services industries when compared with manufacturing, where there has been, in contrast, a fairly rapid decline in trade union membership (Bhorat, Caetano, et al. 2016)

With regard to informal services, the coefficients are large and negative across the entire earnings distribution. In other words, informal services sector workers earn less than manufacturing workers do, regardless of where they are on the earnings distribution. At the $10^{\text {th }}$ percentile, informal services sector workers earn 11.94 per cent less than workers in manufacturing. This increases to 28.21 per cent at the $50^{\text {th }}$ percentile and 27.84 per cent at the $90^{\text {th }}$ percentile. These results only serve to confirm our characterization of the services sector as being dominated by low-productivity, low-skilled, and low-wage jobs. 
Table 4: Quantile earning function estimates

\begin{tabular}{|c|c|c|c|}
\hline Sector & $\begin{array}{l}10^{\text {th }} \text { Percentile } \\
\text { Coefficient }\end{array}$ & $\begin{array}{l}50^{\text {th }} \text { Percentile } \\
\text { Coefficient }\end{array}$ & $\begin{array}{l}90^{\text {th }} \text { Percentile } \\
\text { Coefficient }\end{array}$ \\
\hline Wholesale and retail trade & $15.51^{\star \star \star}$ & $-7.78^{\star \star \star}$ & $-15.14^{\star * *}$ \\
\hline Catering \& accommodation & $7.11^{\star \star *}$ & $-9.58^{\star \star *}$ & $-20.09 * * *$ \\
\hline Transport \& storage & $-14.81^{* * *}$ & $8.26^{\star \star *}$ & $12.79^{* * *}$ \\
\hline Government services & $-0.94^{\star * *}$ & $36.04^{* * *}$ & $15.44^{* * *}$ \\
\hline Other CSP services & $-3.47^{* * *}$ & $-2.78^{\star * *}$ & $-5.07^{* * *}$ \\
\hline Communications & $-6.73^{* * *}$ & $5.79^{\star \star *}$ & $-5.26^{\star \star \star}$ \\
\hline Finance \& insurance & $-1.07^{\star \star *}$ & $10.42^{* * *}$ & $1.15^{\star * *}$ \\
\hline Business services & $-14.31^{* * *}$ & $9.62^{\star \star \star}$ & $-1.44^{\star \star \star}$ \\
\hline TES & $25.37^{* * *}$ & $-9.99^{* * *}$ & $-23.91^{* * *}$ \\
\hline Informal services & $-11.94^{\star * *}$ & $-28.21^{\star \star *}$ & $-27.84^{\star \star \star}$ \\
\hline Pseudo $\mathrm{R}^{2}$ & 0.091 & 0.217 & 0.214 \\
\hline
\end{tabular}

Notes: 1. Manufacturing is the reference group. 2. The dependent variable is the log of monthly wages

3. Excludes the top $1 \%$ of earners and those who reported earning R0 per month. 4 . Controls were included for gender, race, education, age, location, occupation, firm size, experience, union membership and hours of work. 5. ${ }^{* * *}$ Significant at the $1 \%$ level, ${ }^{* *}$ Significant at the $5 \%$ level, * Significant at the $10 \%$ level.

Source: Authors' calculations based on Statistics South Africa (2014).

The estimates for government services suggest two tiers of public sector employees segmented according to skill levels. Firstly, we note a negative estimate at the $10^{\text {th }}$ percentile indicating that government workers at this end of the distribution earn 0.94 per cent less than manufacturing workers. It is possible that these are the lower-skilled workers involved in infrastructure programmes such as the Expanded Public Works Programme. Secondly, there are government employees at the $50^{\text {th }}$ and $90^{\text {th }}$ percentiles who earn 36.04 per cent and 15.44 per cent more than manufacturing workers, respectively. Although these are typically more skilled employees, the wage premium also points to the power of the public sector unions.

The transport and storage coefficients are fascinating, given the skills profile of the industry in relation to manufacturing (see Figure 7). There is a lower proportion of low and highly skilled individuals in transport and storage, relative to manufacturing, and a higher proportion of semiskilled workers. As such, we would perhaps expect that transport and storage would have higher wages at the $10^{\text {th }}$ and $50^{\text {th }}$ percentiles, and lower at the $90^{\text {th }}$ percentile. However, the result reveals a slightly different story. At the $10^{\text {th }}$ percentile, the transport and storage workers earn 14.81 per cent less than manufacturing workers do. At this percentile, we would expect to find individuals working as taxi drivers, delivery van drivers, and so on, who may not be highly unionized. At the $50^{\text {th }}$ percentile, the wage premium in transport and storage is 8.26 per cent, increasing to 12.79 per cent at the $90^{\text {th }}$ percentile. At the $50^{\text {th }}$ percentile, a typical semi-skilled worker such as a truck driver would be represented here. Since semi-skilled workers also dominate manufacturing, we would also expect to see them at the $50^{\text {th }}$ percentile. The wage premium, therefore, is unlikely to be explained by the pure differences in skill sets. Despite having a substantially lower proportion of highly skilled workers than manufacturing, there is a wage premium for transport and storage at the $90^{\text {th }}$ percentile. This might indicate that there is a shortage of highly skilled individuals in the transport and storage sector and as a result, highly skilled workers in this sector are able to exact higher marginal returns.

The estimates for the finance and insurance dummy provide evidence of earnings premia within this industry. Workers in finance and insurance at the $50^{\text {th }}$ and $90^{\text {th }}$ percentiles earn 10.42 per cent and 1.15 per cent more, relative to their manufacturing counterparts. The substantially lower earnings premia relative to government services, at the $50^{\text {th }}$ and $90^{\text {th }}$ percentiles, is indicative of 
lower levels of union density within this industry. The marginally lower relative wage at the $10^{\text {th }}$ percentile for finance and insurance workers is possibly due to the proliferation of lowskilled service workers classified within this sector, but employed through TES firms. Nevertheless, finance and insurance fits within the segment of the services sector characterized by high skills levels, and thus high-productivity levels.

The remaining two modern services sub-sectors-communication and business servicesexhibit a slightly different earnings pattern. Communication and business services have a lower wage relative to manufacturing at the $10^{\text {th }}$ percentile and the $90^{\text {th }}$ percentile of the earnings distribution, but a wage premium at the $50^{\text {th }}$ percentile. A possible explanation for these results is that at the low end of the earnings distribution, there are many more low-skilled workers in communication and business services, hence the lower wages earned relative to manufacturing. However, at the $50^{\text {th }}$ percentile, there are more highly or semi-skilled individuals in these two industries compared to manufacturing, hence the wage premium. The wage premium reverses again at the $90^{\text {th }}$ percentile, perhaps suggesting that highly skilled individuals in communication and business services are not remunerated as highly as in manufacturing.

The results presented in this section indicate that understanding income differentials requires a far more detailed analysis than simply estimating the raw wage gap, based on average wage levels. In sectors that are characterized by low wages, wages at the $10^{\text {th }}$ percentile are higher than manufacturing, but lower when we shift to other parts of the earnings distribution. This is particularly prevalent in the TES sector, which has large coefficients throughout the earnings distribution. The informal services sector has large, negative coefficients regardless of the point on the earnings distribution, suggesting that out of all the services sectors considered, it is the one with the lowest pay. Government services has the highest wage premium as a result of the strong public sector trade unions, while in the three modern services sectors, the story is mixed. Finance and insurance has a smaller premium than government services, while communication and business services has a wage premium at the $50^{\text {th }}$ percentile, but not at the $90^{\text {th }}$ percentile.

The earnings equation estimates above, coupled with the patterns of employment growth across the industries (see Section 4.1.2), suggest an interesting segmentation in the services sector of the South African economy. We observe individuals with relatively higher skills levels and better access to the labour market opportunities located in the modern business, finance and insurance, and communication services industries, as well as in government services. These industries are typically associated with higher levels of productivity and higher returns. In addition, we observe a clustering of employment in industries characterized by relatively lower skill requirements. These include the wholesale and retail trade industry (which is characterized by high levels of informality), and the TES component of business services. The lower skill requirements associated with these industries allow for easier entry into employment, but they are associated with lower levels of productivity and lower returns.

The preceding analysis concerning the segmentation of the services sector provides an analytical lens from which to understand and characterize this sector in South Africa. Firstly, the high-wage premium sectors of modern business, finance and insurance, and communication services serve as the potential platform for a growth and development strategy. Secondly, while the public sector is skills-intensive, the wage premium offered to these workers suggests the formation of a new labour elite (Bhorat et al. 2015), which is both fiscally unsustainable, and certainly not an optimal route to long-run economic growth. Finally, as perhaps the source for large numbers of jobs within the cohort of semi-skilled workers, the formal retail and communication services sectors-under specific conditions such as appropriate export opportunities and competitive wages - do serve as a key opportunity for positive growth and employment opportunities for the South African economy. 
In order to generate sustained long-term economic growth, it is important that service industries exhibit export potential. This is particularly important in the African case, where low global commodity prices have lowered foreign exchange earnings. In this section, we look at the export potential of these industries in the South African case. We start by looking at the export of services abroad. This is followed by an analysis of a specific service export-tourism. The export potential of high value-add agri-processing and high-value horticulture products are considered. The section concludes with an analysis of outbound South African FDI, and a case study of three South African service sector firms that have been successful in the global marketplace.

\subsection{The export of services}

Services have traditionally been considered inputs into the production and trade of goods, or as outputs produced mainly for domestic consumption. Over the last two decades, however, globalization, coupled with advances in technology, have facilitated a rapid rise in the trade of services-driven largely by trade in modern services, such as business, finance, and telecommunications services, as opposed to traditional services such as transport and travel (tourism) services (Mishra et al. 2011) (See Box 1 for explanation on typology of service trade). Services exports have thus become increasingly important not only as a source of export diversification and global competitiveness (Saez et al. 2014), but also as a key driver of economic growth (Mishra et al. 2011).

Given the large and growing role of domestic services in the South African economy, South Africa appears relatively well positioned to reap the growth benefits from the export of services. For the purposes of this section, trade in services data has been obtained from three datasets: World Bank World Development Indicators; World Bank Trade in Services Database; and the South African Reserve Bank. The World Development Indicators and South African Reserve Bank cover Modes 1, 2, and 4, and the Trade in Services Database covers Modes 1 and 2, which we discuss in greater detail in Box 1 below.

\footnotetext{
${ }^{9}$ Refer to the Appendix for more information regarding the definitions of services exports and problems associated with services trade data.
} 


\section{Box 1: Trade in Services}

The tradability of services is influenced by a number of features unique to services, and which also have implications for the measurement of services trade. These features include: (i) intangibility-imports and exports of services are difficult to monitor and measure; (ii) non-storability-production and consumption of services often occur at the same place and time; (iii) differentiation-services are in most cases tailored to specific needs; and (iv) joint production-customers participate in the production of services (Hoekman and Mattoo 2008). To capture these features, the World Trade Organization (WTO) defines trade in services along four Modes of supply:

Mode 1: Cross-border trade-services supplied from the territory of one country into the territory of another.

Mode 2: Consumption abroad-services supplied in the territory of a country to the consumer of another.

Mode 3: Commercial presence-services supplied in the territory of a country to the consumers of another (i.e. FDI).

Mode 4: Presence of natural persons-services supplied by nationals of a country in the territory of another.

Balance of payments (BoP) statistics typically report services trade falling within Modes 1, 2, and 4 -although a large proportion of FDI is considered to be in the services sector (Saez et al. 2014).

\section{Trends in services exports}

In line with global trends, South Africa's exports of services have been modest when compared to goods exports (see Figure 8). In particular, real services exports increased from R33,192 million in 1960, to R117,493 million in 2010; while real goods exports rose from R169,360 million in 1960 to R668,856 million over the same period. As illustrated in Figure 9, growth in real services exports was on a par with growth in real goods exports between 1960 and 1975with real goods exports and real services exports growing at an average rate of 3 per cent and 2 per cent, respectively. However, the 1980s saw a considerable divergence in the growth of goods and services exports. Between 1975 and 1995, real services exports grew at an average rate of 0.3 per cent, while average growth in real goods exports continued at 3 per cent. The dip in services exports growth was likely a result of economic sanctions, and the reversal of foreign capital flows, during the final years of apartheid-which appears to have had a disproportionately negative impact on services exports vis-à-vis goods exports (Levy 1999). Nevertheless, by 2010, growth in services exports had matched that of goods exports growth. 
Figure 8: Trend in value of goods and services exports in South Africa, 1960-2010

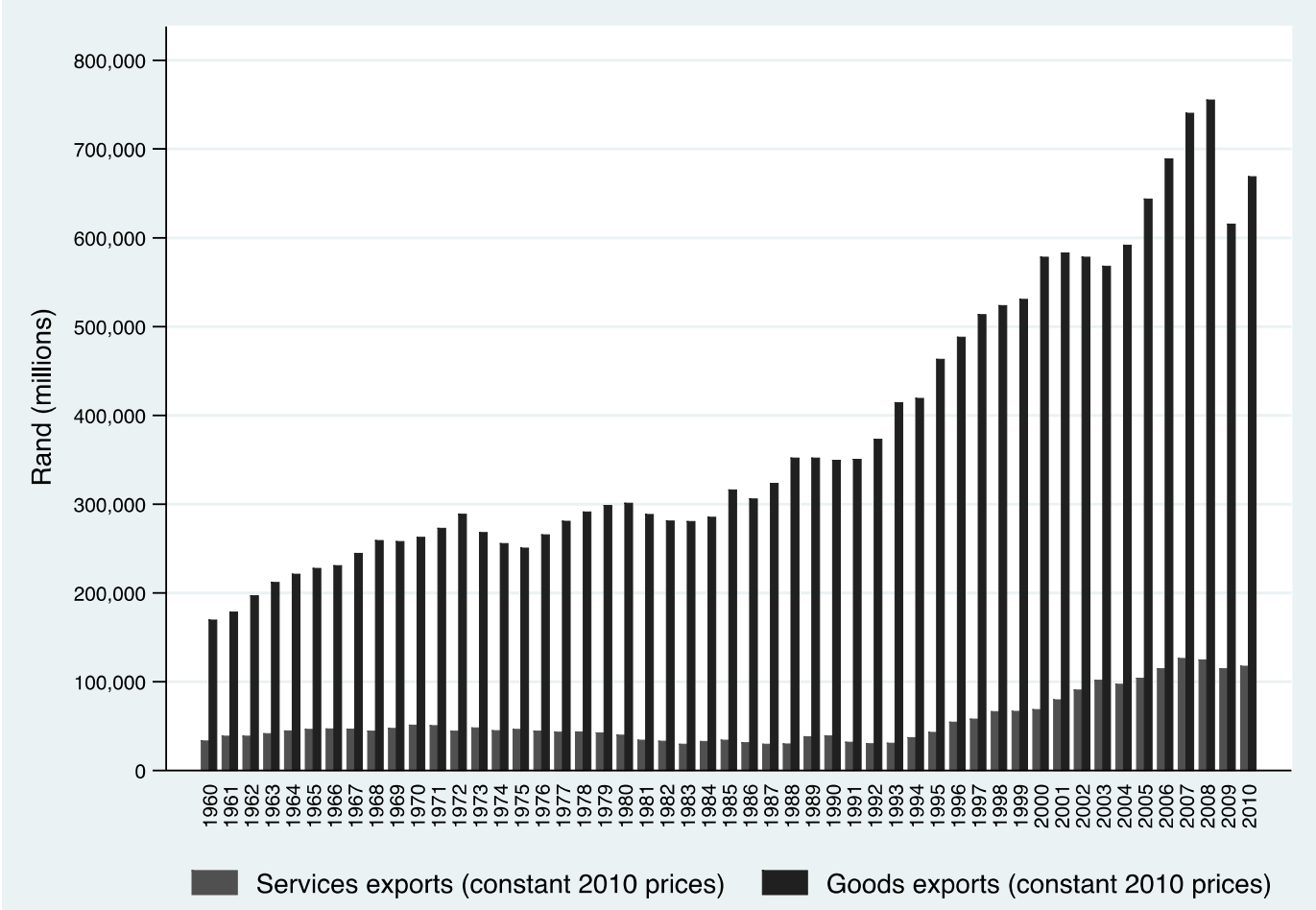

Source: Authors' calculations based on SARB (2016).

Figure 9: Trend in growth of goods and services exports in South Africa, 1960-2010

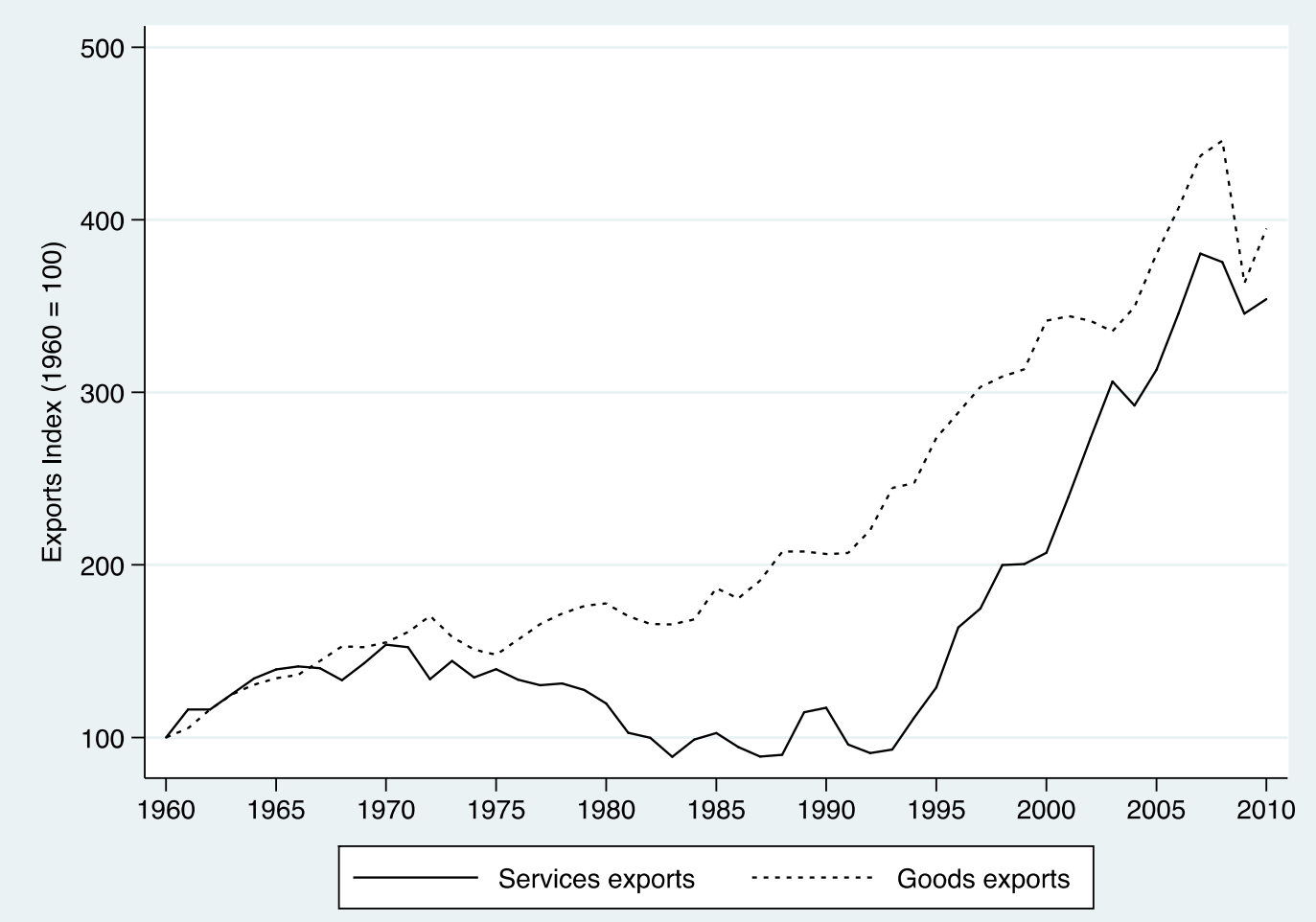

Source: Authors' calculations based on SARB (2016). 
The 'recovery' in services exports in the late 1990s has largely been a result of significant growth in exports of traditional services — and, in particular, travel services—although business services exports are gaining increasing importance in South Africa's services exports basket (as discussed in more detail in Section 4.3.2). It can be argued further that the growth in both goods and service trade in the post-1994 period may be driven by increased liberalization of the economy (Edwards and Lawrence 2008). As illustrated in Figure 10, this recovery is also reflected in a growing, albeit low, share of services exports in total exports. In particular, services exports as a share of total exports increased from a low of 9 per cent in 1988 to 18 per cent in 2003, before declining to 15 per cent in 2010.

Figure 10: Share of services exports in total exports and services value added, 1970-2010

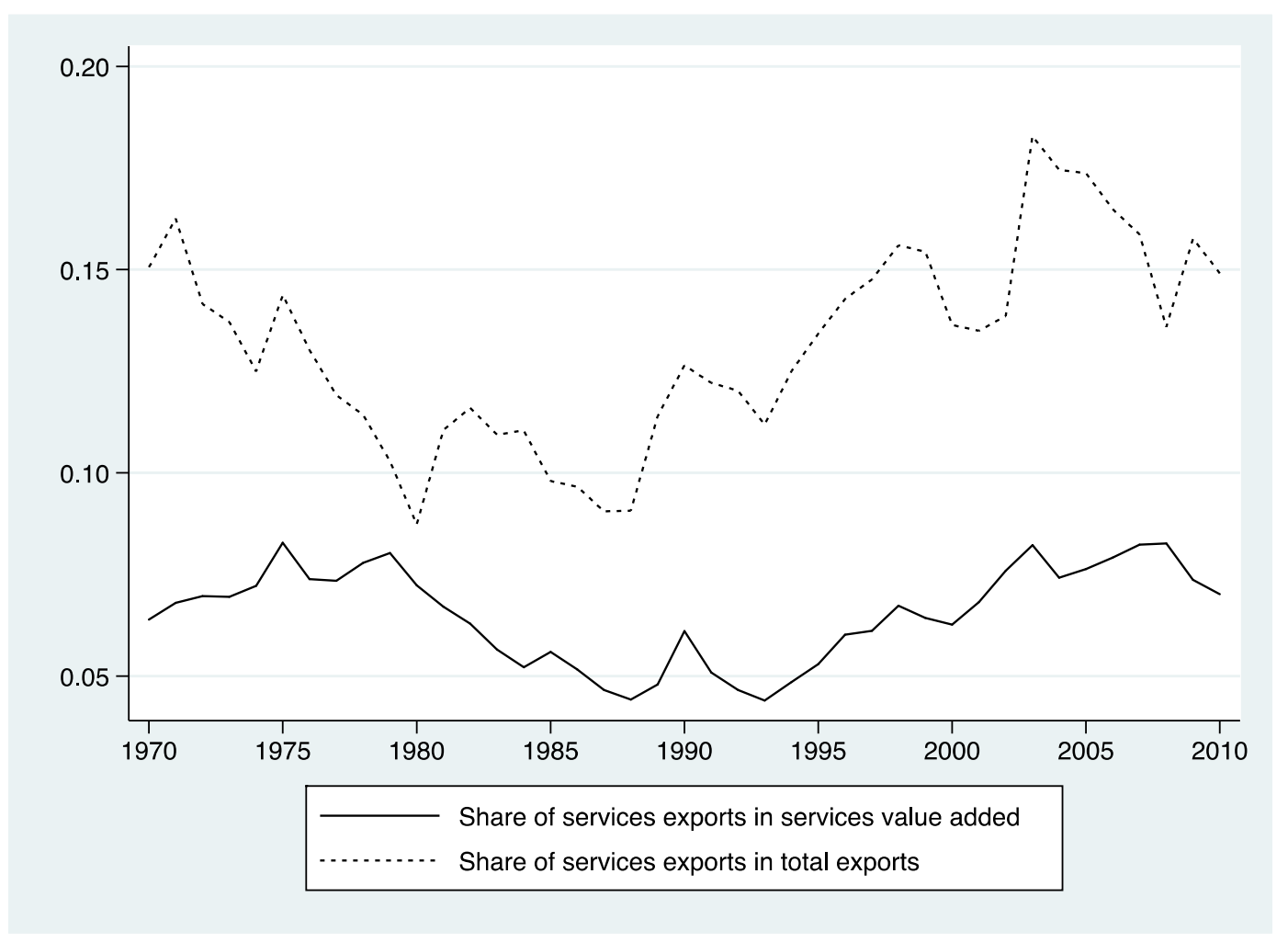

Note: Services exports are BoP figures in current USD.

Source: Authors' calculations based on World Development Indicators (World Bank 2016a).

Figure 10 also shows the share of services exports in services value added-which gives an indication of the tradability and international competitiveness of a country's domestic services sector (Mishra et al. 2011; Saez et al. 2014). While growth in services exports improved, the tradability of South Africa's services sector remained low. In particular, between 2000 and 2010, South Africa exported an average of only 8 per cent of services value added, despite services making up slightly over 60 per cent of GDP. When compared to peer countries on the continent and beyond, South Africa appears to be lagging behind. For instance, with services in Turkey making up a similar share of GDP_on average, 61 per cent between 2000 and 2010 - the average share of services exports in services value added was relatively higher, at 11.7 per cent. ${ }^{10}$ In Ethiopia, where services made up an average of only 42 per cent of GDP between 2000 and 2010, the average share of services exports in services value added was 17.9 per cent. ${ }^{11}$ The

\footnotetext{
10 Authors' calculation using World Development Indicators (World Bank 2016).

11 Authors' calculation using World Development Indicators (World Bank 2016).
} 
limited outward orientation of South Africa's services exports may be indicative of lower productivity, skills constraints, and trade protection in South Africa's services industry relative to other markets, which has hampered improvements in the tradability of South Africa's services sector.

Figure 11 also shows that in terms of services exports growth, South Africa is lagging behind some of its middle-income country peers.

Figure 11: Comparison of services exports growth with selected countries, 1995-2010

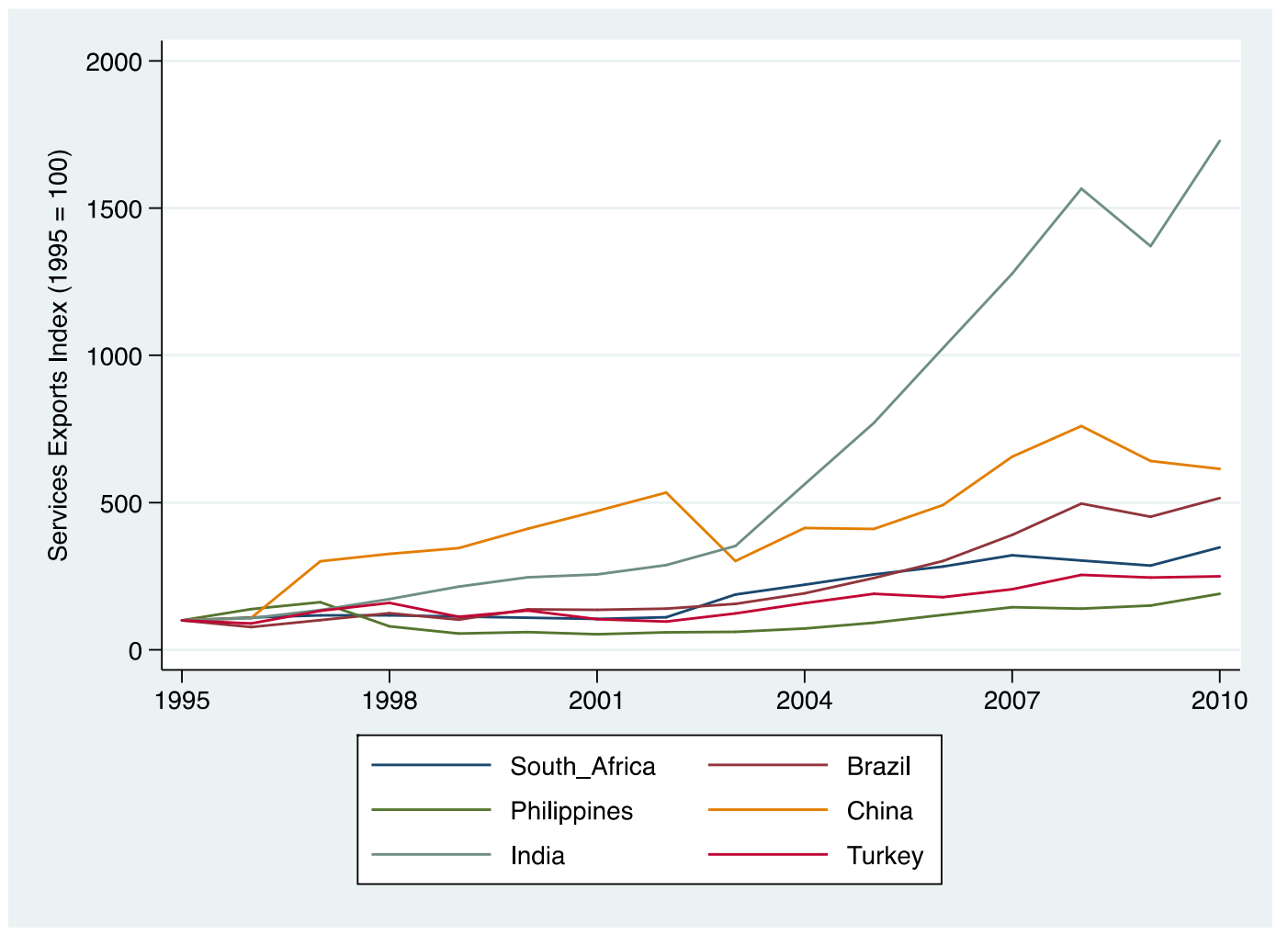

Note: Services exports are BoP figures in current USD.

Source: Authors' calculations based on World Development Indicators (World Bank 2016a).

A comparison of South Africa's services and manufacturing exports also reveals that there is considerable scope to expand services exports, particularly as labour-intensive manufacturing such as clothing and textiles, or ICT goods, have performed relatively poorly domestically and in international markets (Edwards and Alves 2006). As outlined in Table 5, manufacturing exports continue to dwarf services exports, despite manufacturing contributing relatively little to the domestic economy in comparison with services. The ratio of manufacturing exports to services exports declined only marginally from 3.3. to 2.5 between 2000 and 2010 , although services exports have grown in line with manufacturing exports over the period. 
Table 5: Comparison of merchandise and commercial service exports, 2000-10

\begin{tabular}{lllll}
\hline & 2000 & 2005 & 2010 & $\begin{array}{l}\text { Average Annual Growth } \\
(2000-10)\end{array}$ \\
\hline Merchandise exports (current USD) & 29,983 & 51,625 & 91,347 & 13.2 \\
Of which: & & & & \\
Manufactures exports (current USD) & 16,145 & 29,248 & 44,466 & 12.3 \\
Commercial services exports (current USD) & 4,888 & 11,570 & 15,676 & 12.5 \\
Ratio of manufactures to services exports & 3.3 & 2.5 & 2.8 & $\mathrm{n} / \mathrm{a}$ \\
\hline
\end{tabular}

Source: Authors' calculations based on World Development Indicators (World Bank 2016a).

Therefore, the overall trend suggests that while recent growth in services exports has caught up to that of goods exports, services comprise a rather small portion of South Africa's total exports. This is despite the services sector contributing the most value to the domestic economy. This outcome may be a reflection of several bottlenecks including low skill levels in the labour force, trade protection in specific services industries (such as telecommunications), and lower productivity in the services sector, in comparison to other emerging markets such as India and China. However, the composition of South Africa's services exports may also be a factor determining the expansion of South Africa's services exports. As Mishra et al. (2011) argue, the composition of services exports matters. In addition to increasing the volume of services exports, increasing the sophistication and quality of services exports is essential to unlocking sustained and rapid economic growth (Mishra et al. 2011). We assess the composition of South Africa's services exports in the following sub-section.

Composition of services exports

Using the World Bank's TSD, Figure 12 shows the change in composition of South Africa's services exports between 2005 and 2010. As shown in Figure 12, travel services and commercial services have made up the bulk of services exports between 2005 and 2010-although the share of commercial service exports relative to travel service exports declined between 2008 and $2010{ }^{12}$ Specifically, in 2005, commercial services exports were valued at US\$8,064 million compared to US $\$ 2,004$ million for travel service exports; yet by 2010, commercial services exports had declined to US\$3,906.4 million, compared with travel services exports which increased to US $\$ 9,071$ million.

12 Commercial services exports, as per the Trade in Services Database comprise: communications services, construction services, insurance services, financial services, computer and information services, royalties and licences, business services, and personal, cultural, and recreational services. 
Figure 12: Composition of services exports, 2005-10

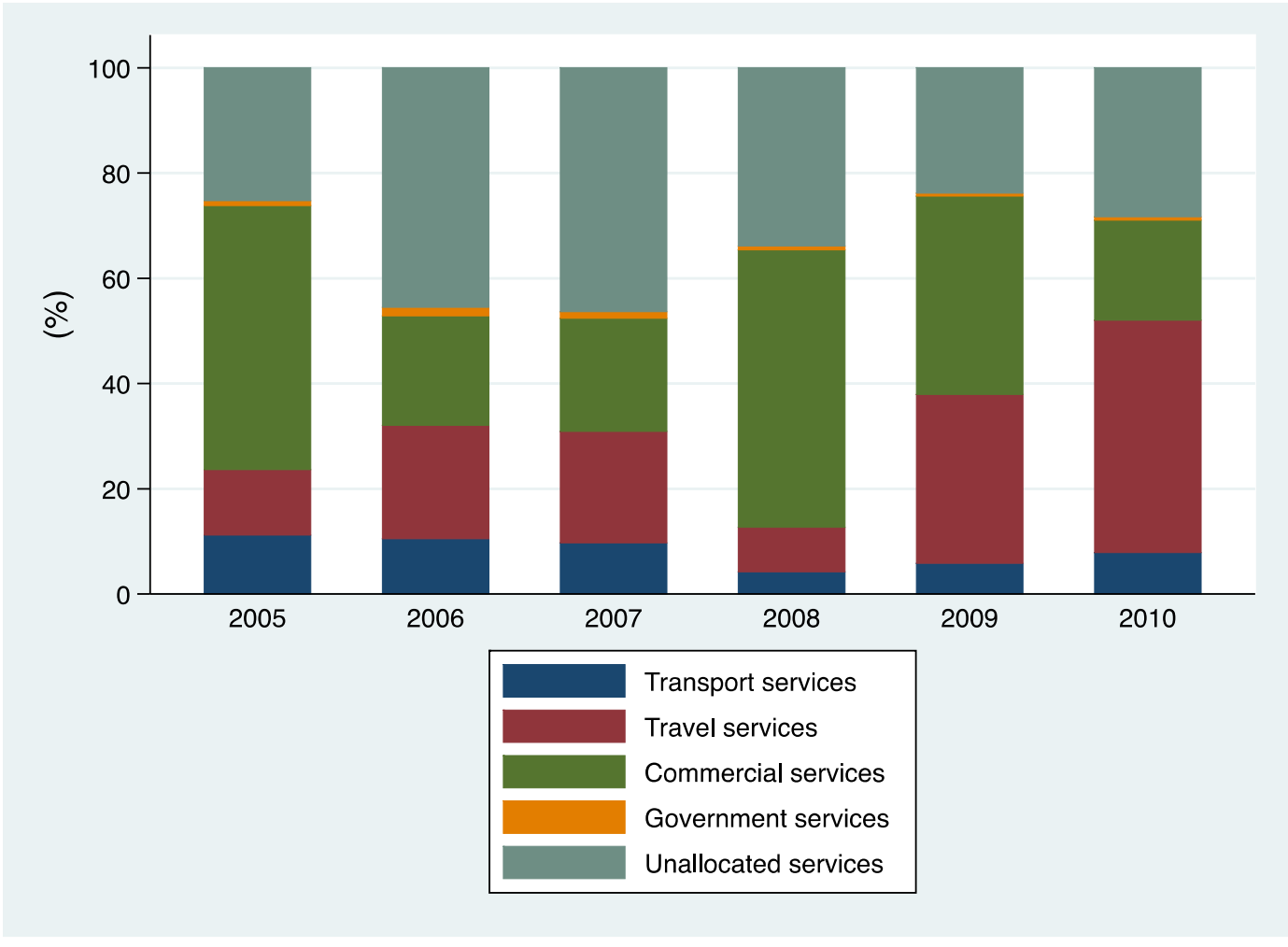

Note: Service exports are total exports to the world ('WLD').

Source: Authors' calculations based on Trade in Services Database (World Bank 2016b).

This suggests that rather than a shift from traditional to modern services, South Africa's services exports appear to have shifted in the opposite direction. This shift is further observed in Figure 13, which shows that while growth in commercial services exports increased in 2008, it has since remained significantly lower than growth in travel service exports, and was marginally lower than growth in transport service exports in 2010. 
Figure 13: Growth in services export categories, 2005-10

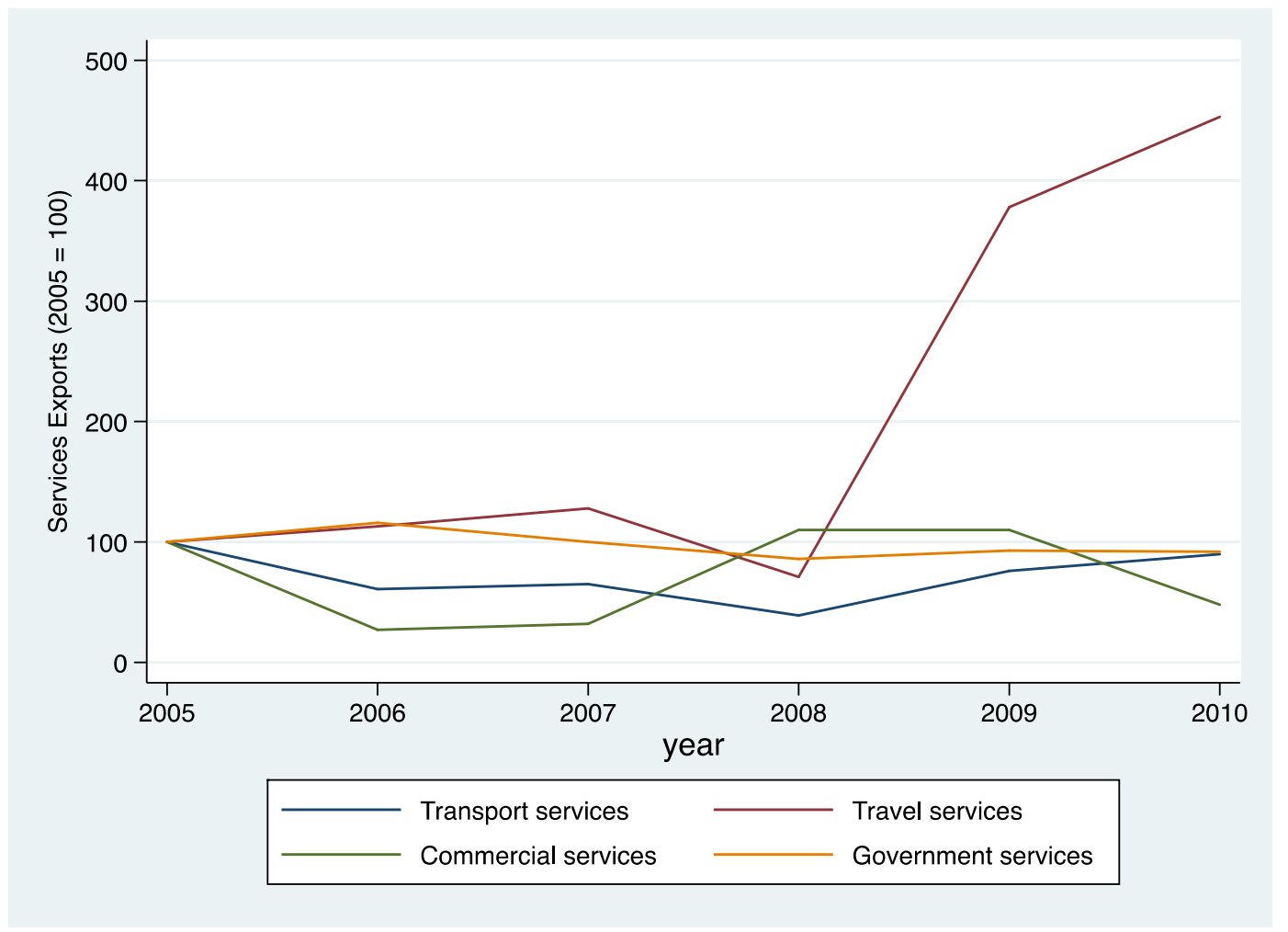

Note: Service exports are total exports to the world ('WLD').

Source: Authors' calculations based on Trade in Services Database (World Bank 2016b).

The rapid growth in travel services exports between 2008 and 2010 is likely a reflection of increased tourism in the run up to the 2010 FIFA World Cup. Although historically, South Africa has been a popular tourist destination on the continent given its diverse natural environment and culture, as well as its relatively well-developed infrastructure (Fourie 2011). The decline in commercial service export growth may be a reflection of several factors, including protection of domestic services industries such as telecommunications, which stifles innovation and motivation for international competitiveness, and a lack of sufficient skills in the labour force which creates a constraint on expansion and also raises the cost of labour, and ultimately the cost of services (Freytag 2011).

Examining the composition of South Africa's commercial services exports more closely, Figure 14 shows that since 2005, commercial services exports have been dominated by exports of 'other business services'-although the value of these exports declined from US\$5,998 million in 2005 to US $\$ 3,299$ million in $2010 .^{13}$

13 As reported in Trade in Services Database (2016b). Other business services includes: i) merchant and other trade- related services; (ii) operational leasing services; and (iii) miscellaneous business, professional, and technical services, which are made up of (a) legal, accounting, management consulting, and public relations, (b) advertising, market research, (c) research and development, (d) architectural, engineering, and other technical services, (e) agricultural, mining, and on- site processing services, (f) other business services, and (e) services between related enterprises. 


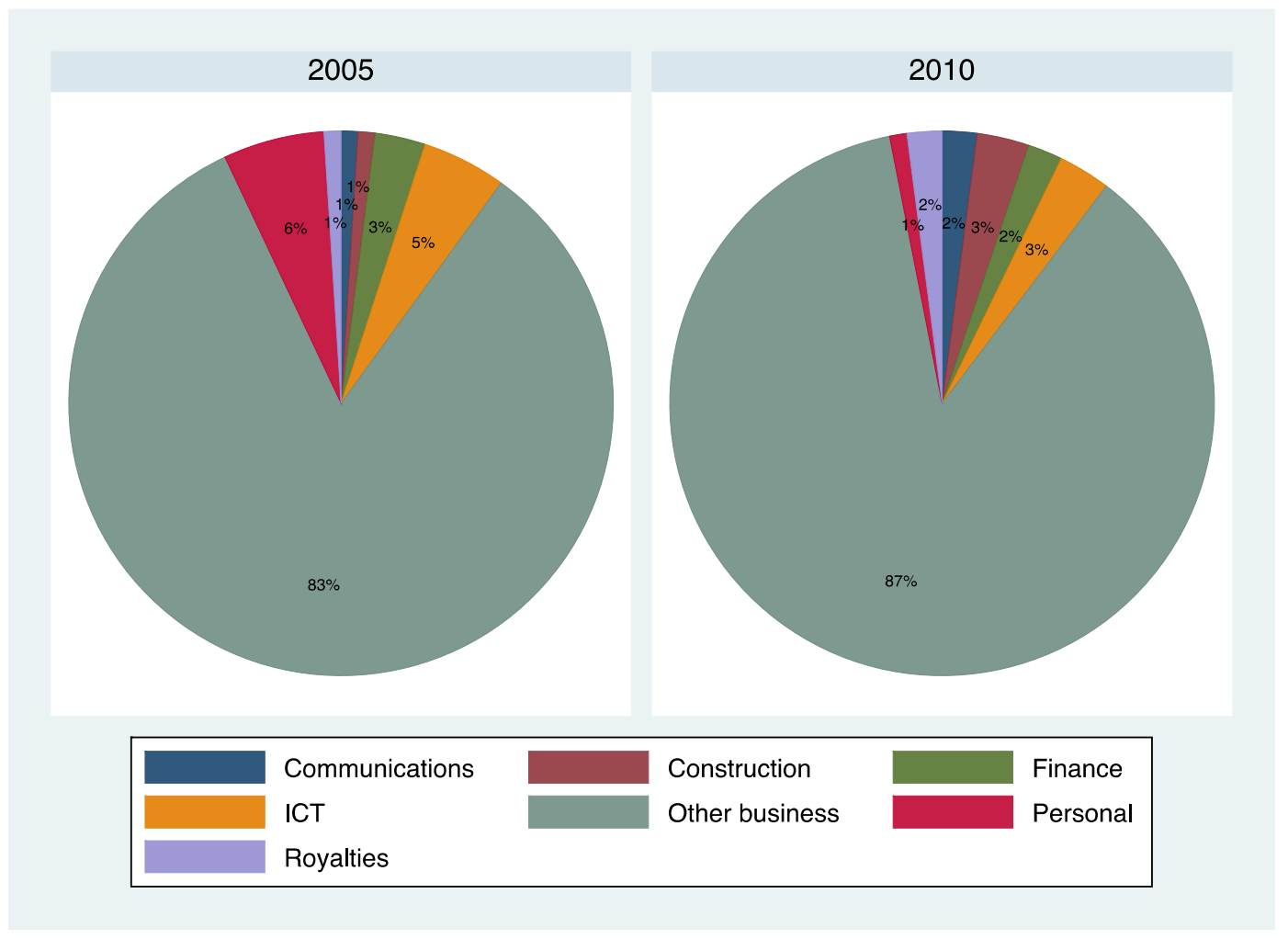

Source: Authors' calculations based on Trade in Services Database (World Bank 2016b).

Communication and construction exports increased marginally between 2005 and 2010, while computer and information services (ICT) declined from 5 to 3 per cent of commercial services exports over the period. Insurance services exports were negligible in 2005, but increased to 2 per cent of commercial services exports in 2010, while the share of financial services remained constant during the period. The share of commercial services exports that can be considered 'high quality'-i.e. communications, computer and information, and insurance and financial services, has remained relatively low over the period. This indicates that the current composition of South Africa's services may not be sufficient to generate the levels of growth seen by its middle-income country peers, like India and China. However, given the sophistication of South Africa's financial services sector, and its rapid expansion into the rest of the African continent, it is likely that the TSD underestimates the value of South Africa's insurance and financial services exports. ${ }^{14}$ In particular, one of the country's leading financial institutions-Standard Bank-was noted to have a presence in 17 countries on the African continent in 2010, with several subsidiaries in other countries around the world (Standard Bank 2010).

Nevertheless, given that 'other business services' has constituted the largest portion of services cross-border trade and consumption abroad, further insight into what makes up these exports for South Africa may be revealing. In particular, the TSD shows that South Africa's business services exports have been made up almost exclusively of merchant and trade related services,

\footnotetext{
${ }^{14}$ In addition, given that much of this expansion has been through the setting up of branches and local subsidiaries in other countries, this will not be captured in the TSD as it covers only services exports in Modes 1 and 2, which do include exports via a commercial presence (Mode 3).
} 
and miscellaneous business services, ${ }^{15}$ suggesting that South Africa's services exports remain largely geared toward supporting the exports of goods. In 2010, these exports were made up of legal and accounting services, followed by research and development, architectural and engineering services, and services between related parties. Despite limited exports of hightechnology services, further specialization within these businesses services exports-particularly in $\mathrm{R} \& \mathrm{D}$ and engineering services-can still yield considerable gains for economic growth.

The overall composition of services exports therefore suggests that South Africa's services exports remain largely centred on travel and tourism, and on services that support the exports of goods. Unlike other emerging economies, South Africa has not experienced a distinct shift away from traditional services exports toward modern, 'high-technology' exports. In fact, the value of commercial services exports, as per the TSD definition, declined relative to travel exports between 2005 and 2010, while growth in commercial services exports remained marginal when compared to growth in travel services exports over the period. As indicated above, South Africa lags behind its emerging market peers with regard to the sophistication of its commercial services exports, especially as communications and ICT exports have remained below 5 per cent of commercial services exports. While travel services exports have been boosted by the 2010 World Cup, and South Africa's position as a popular tourist destination on the continent, commercial services exports have been hampered largely by domestic factors such as labour market constraints, and inadequate trade policies.

An important data omission, however, is South Africa's services trade with other African countries, which is largely FDI and therefore not captured in the TSD. South Africa has a large presence of banks and other financial institutions, as well as retail companies-such as clothing and fast-moving consumer-good retailers-on the African continent, suggesting that without these operations accounted for, the value and sophistication of the country's services exports, particularly in financial services, may be underestimated.

In addition to enhancing the quality and sophistication of services exports, the literature on trade in services suggests that growth into new export markets or service sectors ('extensive margin'), as well as the intensification of existing export relationships ('intensive margin'), is essential for export growth and ultimately for economic growth (Brenton and Newfarmer 2009; Besedes and Prusa 2011). Taking into account the limitations in the TSD, there are indications that there has been limited growth into new services markets between 2005 and 2010-particularly, telecommunication and other ICT-related markets. The following sub-section provides a simple assessment of South Africa's entry into new export markets, and the intensification of key export relationships, between 2005 and 2010. Possible implications of revealed comparative advantage for South Africa's services exports are also discussed.

\section{Market penetration and revealed comparative advantage}

Using the TSD, this section provides a profile of South Africa's top destinations for services exports between 2005 and 2010, as well as the change in revealed comparative advantage over time. While the TSD allows for both broad and detailed insight into bilateral trade flows in services, a key weakness of the database is that a large proportion of 'South-South' trade is under- or poorly reported. Based on discussion with officials at the National Treasury, South

\footnotetext{
15 As per the Trade in Services Database (World Bank 206b), miscellaneous business, professional, and technical services comprise: legal, accounting and management consulting services; advertising and market research services; research and development services; architectural and engineering services; agricultural, mining and on-site processing services; other business services; and services between related parties.
} 
Africa only records services trade in three categories - travel, transport, and other business-and these flows are not reported at the bilateral level (service-destination). Therefore, the bilateral trade in services data for South Africa captured in the TSD is most likely mirror data (i.e. trade transactions recorded at the importer side). Typically, the measuring, categorization and reporting of trade in services is performed in greater detail in developed countries. Consequently, the TSD captures mainly trade in services between developed countries, including 'North-South' trade, and thus possibly underestimates the volume of services exports for developing countries that may trade primarily with other developing countries. In any case, it is assumed that trade between developing countries is likely captured in the 'XWD' region, which holds unallocated imports and exports of services for each country. For this section, we therefore use 'XWD' as a proxy for developing countries.

In 2005, South Africa's services exports reached 57 countries, most of which are developed and emerging market countries in Europe, Asia, and North and South America. By 2010, however, South Africa's services exports reached only 37 countries-with the contraction in trade stemming mainly from the apparent closing out of services' export relationships with other emerging market countries, including China, Brazil, Thailand, Vietnam, and the Philippines. ${ }^{16}$ Table 6 displays the top ten importers of South Africa's services exports in terms of value in 2005 and 2010, including the 'XWD' region as a proxy for trade with other developing countries.

As shown in Table 6, there have been notable shifts in the top ten destinations for South Africa's services exports. In 2005, services exports to Japan made up 15.1 per cent of total services exports, and were comprised almost exclusively of merchant and trade related services, and transport services. By 2010, however, the value of services exports to Japan declined considerably; exports to Japan making up only 1.8 per cent of total services exports. South Africa was no longer exporting merchant and trade related services to Japan, and the value of transport services exports to Japan had declined. On the other hand, South Africa's services exports to France increased somewhat considerably over the period, from US\$356 million in 2005 to US $\$ 622$ million in 2010. Services exports to France in 2005 were made up mainly of transport services, travel services, miscellaneous business services, and royalties and licence fees. In 2010, miscellaneous business services and construction services gained more prominence, although travel services remained the largest component of services exports to France.

\footnotetext{
16 These figures do not take into account the unallocated bilateral trade flows in the 'XWD' region, although, it is unlikely that the number of partner countries included in the 'XWD' would reverse this trend.
} 
Table 6: Top ten destinations for South Africa's services exports, 2005 and 2010

\begin{tabular}{|c|c|c|c|c|c|c|}
\hline \multicolumn{4}{|c|}{2005} & \multicolumn{3}{|l|}{2010} \\
\hline & Country & $\begin{array}{l}\text { Value } \\
\text { (USD millions) }\end{array}$ & $\begin{array}{l}\text { Share of } \\
\text { total exports } \\
(\%)\end{array}$ & Country & $\begin{array}{l}\text { Value } \\
\text { (USD millions) }\end{array}$ & $\begin{array}{l}\text { Share of } \\
\text { total exports } \\
\text { (\%) }\end{array}$ \\
\hline 1. & Japan & $1,954.83$ & 15.1 & 'XWD' & $6,793.30$ & 46.1 \\
\hline 2. & United Kingdom & $1,929.08$ & 14.9 & $\begin{array}{l}\text { United } \\
\text { Kingdom }\end{array}$ & $2,074.40$ & 14.8 \\
\hline 3. & USA & $1,319.40$ & 10.2 & USA & $1,711.39$ & 11.6 \\
\hline 4. & Germany & $1,163.00$ & 9.0 & France & 621.66 & 4.2 \\
\hline 5. & Netherlands & 770.26 & 5.9 & Netherlands & 398.47 & 2.7 \\
\hline 6. & Italy & 710.68 & 5.5 & Belgium & 396.18 & 2.7 \\
\hline 7. & 'XWD' & 634.21 & 4.9 & Germany & 323.87 & 2.0 \\
\hline 8. & Ireland & 487.74 & 3.8 & Japan & 287.95 & 1.8 \\
\hline 9. & France & 356.37 & 2.8 & Ireland & 266.24 & 1.8 \\
\hline 10. & India & 288.40 & 2.2 & Denmark & 257.78 & 1.5 \\
\hline
\end{tabular}

Note: Value and share of services exports is for reported total extended balance of payments services (EBOPS).

Source: Authors' calculations from Trade in Services Database (World Bank 2016b)

The value of services exports to the United Kingdom and USA also increased over the period, although their share in South Africa's total services exports remained relatively constant. In 2010, travel and transport services were the predominant service export to the United Kingdom, unlike in 2005 in which merchant and trade related services were also included in the basket of services exports to the United Kingdom. While travel services exports were also the main service export to the USA in 2010, miscellaneous business services-mainly legal, accounting, and management consulting-comprised a sizeable portion of services exports to the USA.

The biggest shift in market penetration for South Africa's services exports has been in the 'XWD' region, suggesting that South Africa may have intensified export relationships with developing countries (most likely in Sub-Saharan Africa), over the period. Services exports to this region increased significantly from 4.9 per cent of total services exports in 2005, to 46 per cent of total services exports in 2010. This could be an indication that South Africa's services exports are growing into new markets, particularly on the African continent. As discussed in Section 5.1.2, the expansion of South Africa's financial services and retail sectors into the rest of the continent may be fuelling this trend.

Despite some positive expansion into a few new markets, services export relationships in several key markets, particularly in Europe, have not intensified. Although Denmark joined the group of top destinations for South Africa's services exports in 2010, the share in total exports for Germany, the Netherlands, and Ireland, decreased between 2005 and 2010. Italy and India were also no longer prominent export destinations in 2010. While export growth into new markets and regions is important for economic growth, the ablity to sustain and grow existing export relationships over time is considered to have a larger impact on export growth and economic growth (Besedes and Prusa 2011). The overall picture for South Africa indicates that the intensification of export relationships over time has not been particularly successful. It also appears that while tourism and travel services exports are being driven mostly by trade from the North, South Africa's commercial services exports may be driven more by trade with developing countries on the African continent and beyond. 
Looking ahead, an assessment of the revealed comparative advantage of South Africa's services exports could give insight into services sectors that could be leveraged to boost growth and specialization in services exports. The revealed comparative advantage (RCA) ratio for a country compares the share of a sector's exports in the country's total exports, with its share of world exports. The higher the RCA ratio, the more competitive the country is in that sector (Saez et al. 2014). Table 7 provides the RCA ratio and share in total services exports for the main components of services exports in 2005 and 2010.

Table 7: Exports share and revealed comparative advantage for services exports, 2005 and 2010

\begin{tabular}{lllll}
\hline & $\begin{array}{l}2005 \\
\text { Share in } \\
\text { total exports (\%) }\end{array}$ & RCA & $\begin{array}{l}2010 \\
\text { Share in } \\
\text { total exports (\%) }\end{array}$ & RCA \\
\hline Transportation & 16.4 & 0.9 & 11.1 & 0.8 \\
Travel & 18.2 & 0.9 & 62.2 & 2.3 \\
Communications services & 0.3 & 0.2 & 0.5 & 0.2 \\
Construction services & 0.9 & 0.5 & 0.9 & 0.3 \\
Insurance services & 0.3 & 0.1 & 0.4 & 0.1 \\
Financial services & 1.7 & 0.6 & 0.7 & 0.2 \\
Computer and information & 3.3 & 1.5 & 0.8 & 0.2 \\
services & & 0.1 & 0.5 & 0.0 \\
Royalties and licence fees & 0.5 & 1.4 & 22.6 & 0.8 \\
Other business services & 54.5 & 1.0 & 0.4 & 0.4 \\
Personal, cultural, and & 3.9 & & & \\
recreational services & & & & \\
\hline
\end{tabular}

Source: Authors' calculations from Trade in Services Database (World Bank 2016b)

In 2005, the RCA ratio was highest, and greater than one for computer and information services followed by business services, suggesting a comparative advantage in 'high-quality' services. By 2010, however, this had changed dramatically. The RCA ratio for computer and information services declined to 0.2 , and that for other business services declined to 0.8. Conversely, the RCA ratio for travel services exports increased substantially from 0.9 in 2005, to 2.3 in 2010. This change over time further indicates the shift in South Africa's services exports toward traditional services, rather than toward modern services that drive rapid economic growth. As indicated in Section 5.1.2, the shift toward a strong comparative advantage in travel services is likely the result of increased international coverage and attention paid to South Africa in the run up to, and during the hosting of, the 2010 World Cup. On the other hand, a drop in comparative advantage for computer and information services may reflect lost competition to more productive suppliers in India and China, as well the other aforementioned constraints such as trade protection and slow growth in human capital accumulation.

Overall, South Africa's services exports appear to be driven simultaneously by demand for tourism and travel services from Europe and North America, and demand for relatively more sophisticated services such as financial and retail services, in other developing countries mainly on the African continent. This suggests that while South Africa has not been successful in maintaining and growing export relationships with the North, there seems to have been a significant improvement in the intensification of regional trade relationships. However, there has been little growth into the telecommunications and ICT services markets. At the bilateral level, there are indications that the sophistication of exports to key markets has improved. For instance, exports to France in 2005 comprised largely travel and transport services, but in 2010 included construction services. Similarly, exports to the USA in 2010 included legal, accounting, and management consulting services. 
Interestingly, South Africa's comparative advantage seems to have shifted toward traditional services, and in particular, travel services, while the country's comparative advantage in ICT services, financial services, and other business services has declined over time. By 2010, South Africa had a relatively high comparative advantage, as indicated by the RCA, in only three services export markets: travel, transport, and other business services. Focusing efforts solely on where comparative advantage is revealed may limit opportunities to enhance services exports in other more productive sectors, however, as a wide range of factors influence such comparative advantage metrics (Saez et al. 2014). In particular, the quality of trade policies and regulations, technology infrastructure, as well as the level of skills and education in the labour force, can have sizeable impacts on the services sectors that gain strong comparative advantage (van der Marel 2011). These factors appear to be key constraints to the role of services in the South African economy. Without addressing these constraints, it is likely that South Africa will continue to lag behind its peers in exporting more productive, 'high-quality' services, and ultimately lag behind in generating rapid and sustainable economic growth.

The preceding analysis alludes to the importance of travel service exports, and hence tourism. Therefore in the next section, we investigate the export and employment potential of the South African tourism industry.

\subsection{Tourism energizes South Africa's economy}

As the world has become more inter-connected, tourism has emerged as one of the pivotal service export sectors for many countries, particularly developing countries. Tourism is an important driver of economic growth around the world, accounting for approximately 277 million jobs, and constituting some 9.8 per cent of global GDP in 2014 (Daly and Gereffi 2017, forthcoming). South Africa, with its multitude of cultural, historical, and scenic sites, has been well placed to take advantage of this rise in demand for tourism (Phiri 2016). In addition, South Africa's successful hosting of sporting events such as the Rugby World Cup (1995), Cricket World Cup (2003), and Soccer World Cup (2010)—which attracted many first-time visitors - has further reinforced South Africa as a premier tourist destination (Phiri 2016).

South Africa has a well-developed tourism industry when compared with other African countries. In 2014, 9.5 million tourists visited South Africa-by far the biggest in Sub-Saharan Africa and third only to Morocco (10 million) and Egypt (9.6 million) (UNWTO 2015). In terms of total tourism spend, Daly and Gereffi (2017, forthcoming) show South Africa to be the second largest tourism market in Africa, behind Egypt. The South African travel and tourism industry's absolute contribution to GDP (US\$9.7 billion), employment $(702,000)$ and capital investment (US $\$ 5$ billion) compares favourably with the African averages of US $\$ 1.6$ billion, 193,000 , and US $\$ 0.6$ billion, respectively. In this context, we evaluate whether the tourism industry can continue to be a growth driver-both in terms of employment and inclusivity.

\section{Tourism and GDP}

In order to gauge the economic contribution of tourism, we compare the tourism sector to other selected sectors. Measuring the economic contribution of tourism cuts across many sectors (e.g. wholesale and retail, transport) so the other sectors were chosen on the basis that they have little or no relationship with tourism.

Figure 15 shows that economically speaking, tourism constitutes a similar share of GDP to agriculture (around 3 per cent), and this contribution has remained constant over the past decade. In other words, tourism is growing at the same rate as the economy as a whole. Although manufacturing and mining contribute far more to the South African economy than 
tourism, both sectors have declined over the past decade, and there is no indication that this trend is likely to reverse in the future.

As alluded to above, government services is the only sector that has shown sustained growth over this post-2000 period. This can be attributed to the big increase in employment in the sector, as well as the generous public sector wage hikes bargained for by the strong public sector wage unions (Bhorat et al. 2015).

Figure 15: Contribution to GDP by selected sectors (\%)

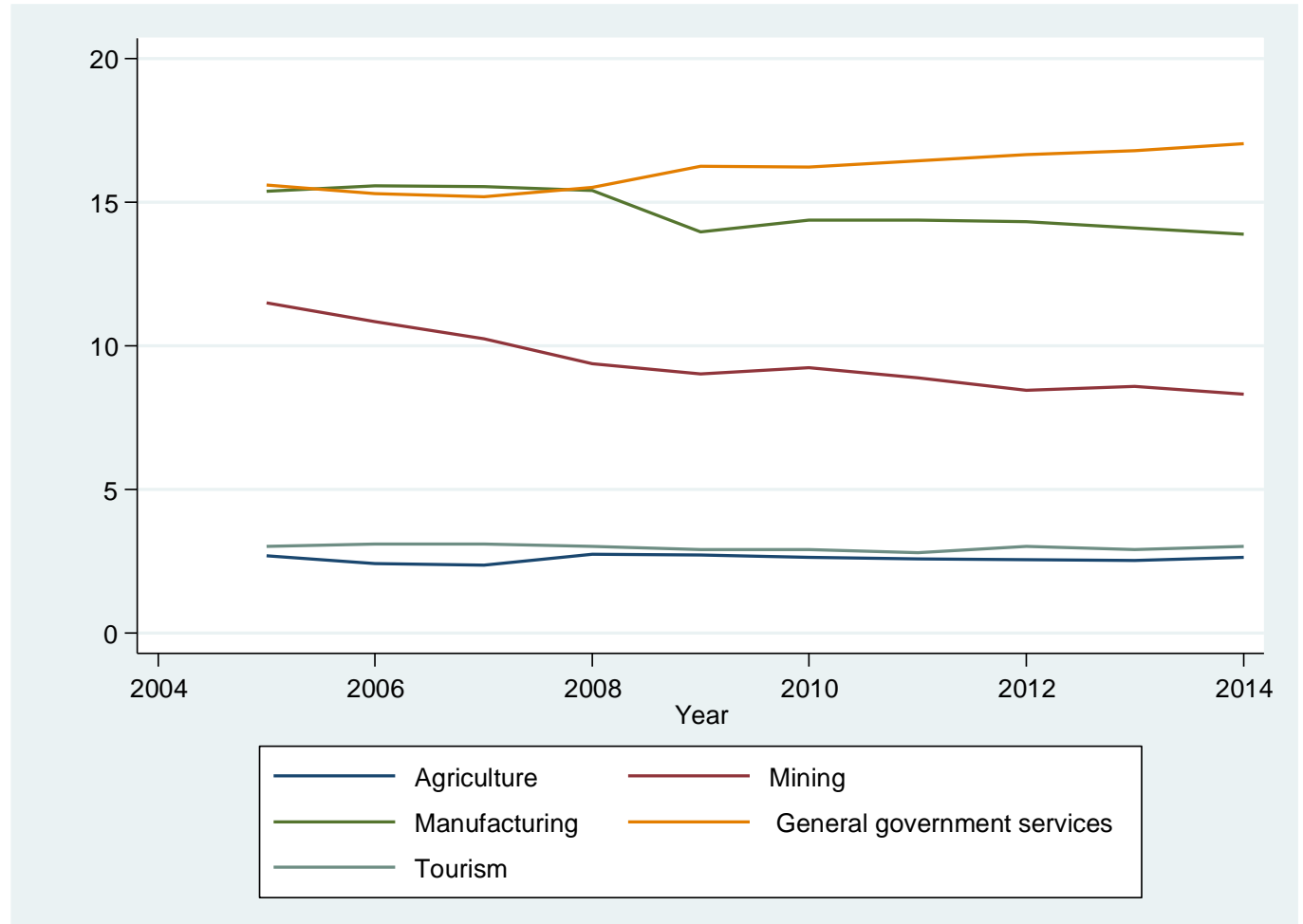

Source: Authors' calculations from various Quarterly Labour Force Survey reports and Tourism Satellite Accounts (Statistics South Africa n.d., 2012, and 2015a).

\section{Tourism and employment}

In 2005 , the number of jobs dependent on tourism was approximately $475,000 .{ }^{17}$ This has risen to 680,000 in 2014 , representing an annual average growth rate of 4.1 per cent. ${ }^{18}$ The aggregate annual growth rate for employment in South Africa was 2.7 per cent over the same period. In Figure 16, we compare the growth rate in employment between the tourism industry and overall employment.

\footnotetext{
${ }^{17}$ Based on data from Statistics South Africa's Tourism Satellite Accounts, 2005-12 (Statistics South Africa 2012).

${ }^{18}$ Based on data from Statistics South Africa's Tourism Satellite Accounts, 2013-14 (Statistics South Africa 2015a).
} 
Figure 16: Tourism and overall employment growth (\%)

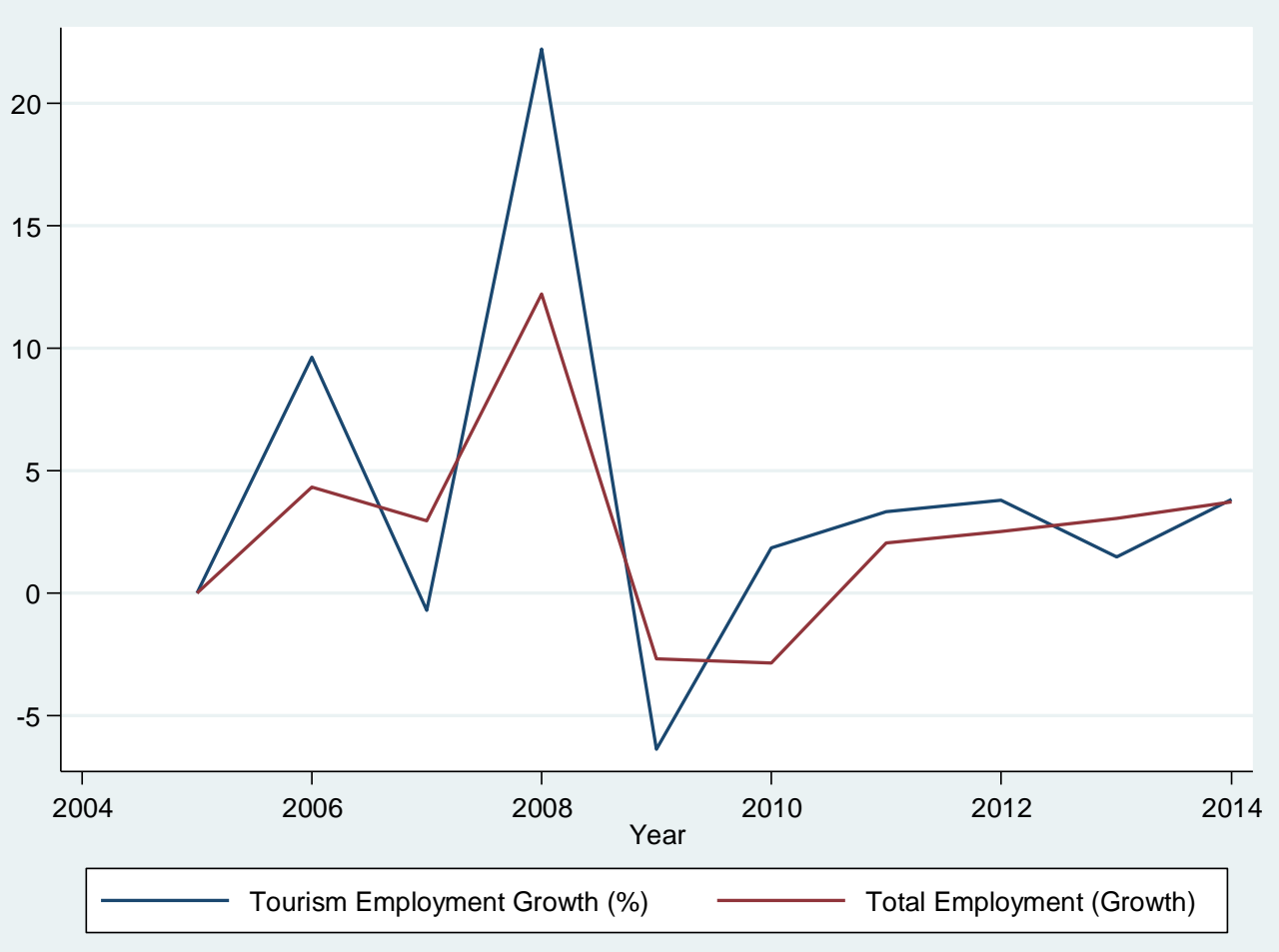

Source: Authors' calculations from various Quarterly Labour Force Survey reports and SA Tourism Satellite Accounts (Statistics South Africa n.d., 2012, and 2015a).

In comparison with the aggregate national employment growth rate for South Africa, the employment growth rate for tourism is more volatile. For example, between 2007 and 2008, the number of employed increased by 12 per cent-for tourism, this increase was approximately 22 per cent. After the financial crisis, while the overall number of jobs decreased by 2.7 per cent, for tourism, this decline was at 6.4 per cent.

However, as illustrated in Figure 17, tourism has recovered faster than many industries since the financial crisis. Since 2008, it has added 48,000 jobs. Although this figure is far less than that of finance and CSP services, we should be cognizant of the fact that the tourism industry is heavily influenced by factors outside its control, such as the strength of a country's currency, political stability, and security. 
Figure 17: Number of jobs gained/lost between 2008 and 2014 ('000s)

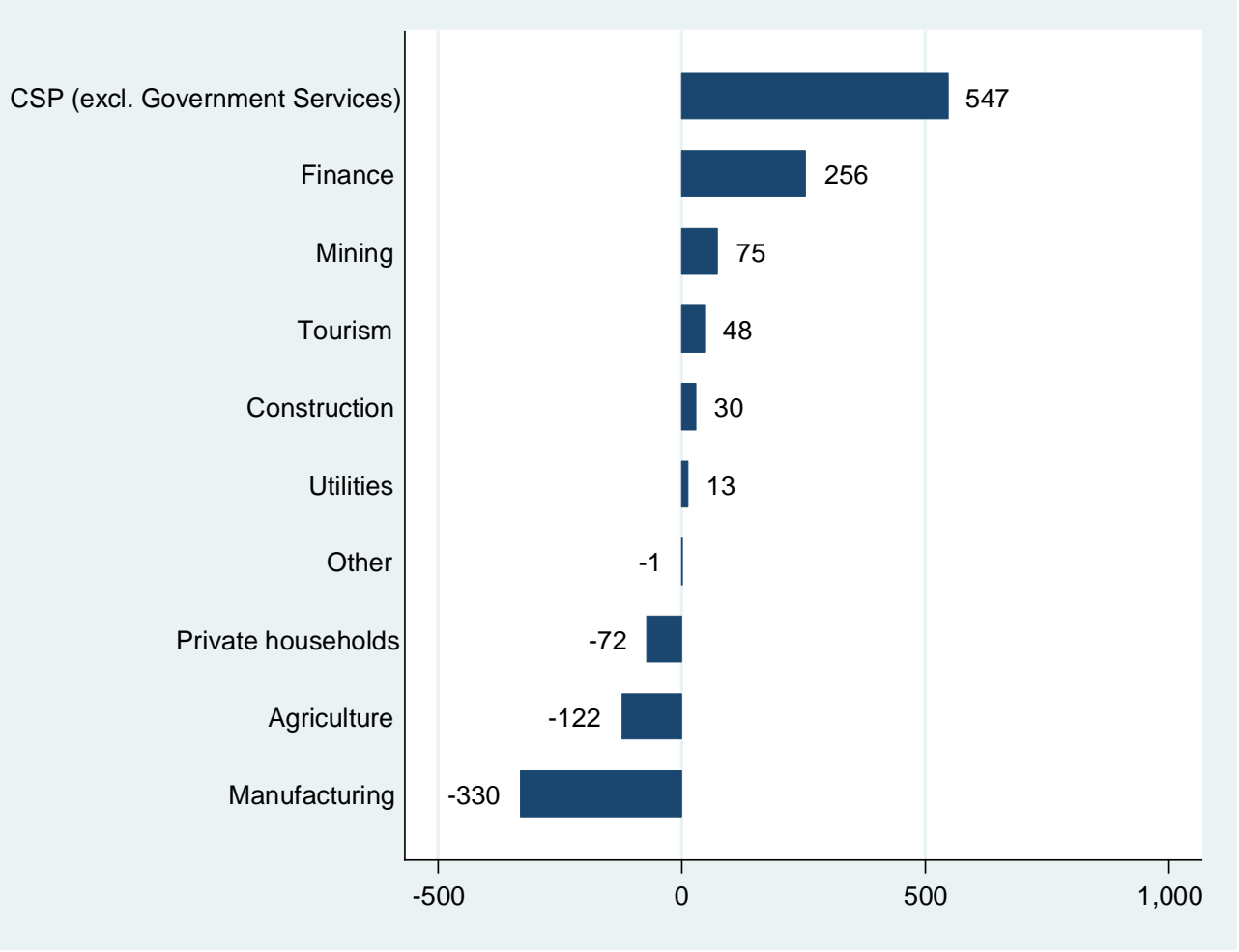

Note: The LMDS does not have a category for tourism. Therefore, the two industries linked most strongly to tourism—wholesale and retail trade and transport-were excluded, as one cannot distinguish between tourism and non-tourism related jobs. Government services was excluded from the CSP category due to government involvement in the tourism industry.

Sources: Authors' calculations from various Quarterly Labour Force Survey reports and SA Tourism Satellite Accounts (Statistics South Africa n.d., 2012, and 2015a).

In order to gain a greater understanding of the tourism industry, we now examine the industries in which tourism jobs are located. Figure 18 shows the percentage of jobs in each industry directly related to tourism. For example, 36 per cent of jobs in the food and beverage industry are directly related to tourism. We observe that there is heterogeneity across the industries in terms of dependence on tourism jobs. At the bottom end, only 7 and 8 per cent of railway passenger transport, and retail and trade jobs, are directly related to tourism, respectively. At the other end of the scale, 91 per cent of jobs in the air passenger transport industry are directly related to tourism, and this number rises to 98 per cent for travel agencies. Overall, there are five (out of 11) industries in which the percentage of jobs which directly depend on tourism exceeds 50 per cent. 
Figure 18: Jobs reliant on tourism, by sector (\%)

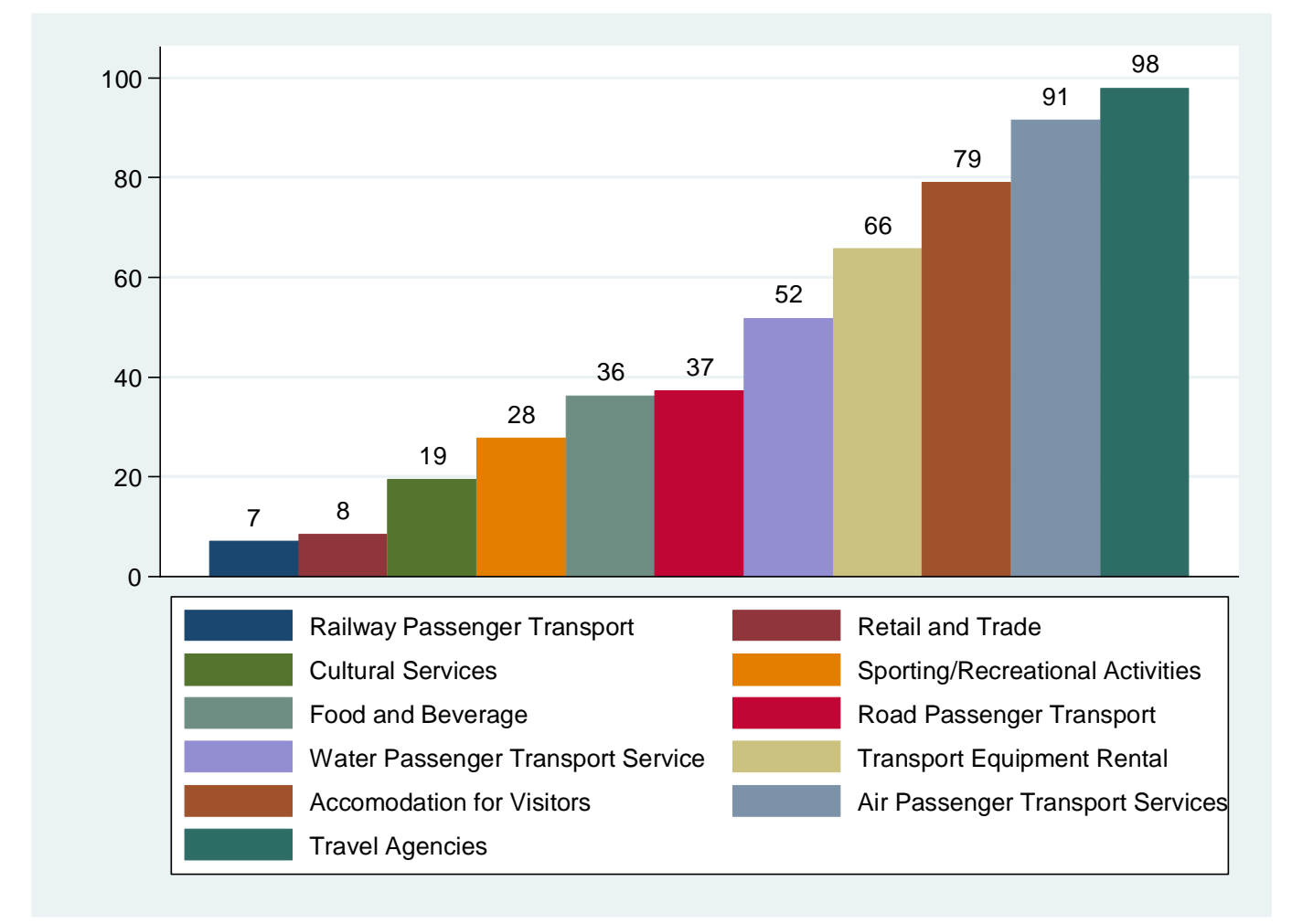

Source: Authors' calculations from Tourism Satellite Accounts (Statistics South Africa 2012, 2015a).

Having shown which industries are most reliant on tourism, we now investigate which industries have the largest number of tourism-related jobs. It is evident in Figure 19 that four industriesroad passenger transport, food and beverage, retail and trade, and accommodation for visitorsare responsible for the significant share of tourism-related jobs (83 per cent). In other words, the total quantum of jobs generated in tourism is largely dependent on these four industries. Interestingly, only the accommodation sector is heavily reliant on tourism, while the other three sectors have a moderate reliance on tourism. In the next section, we explore the ability of these four industries to create more jobs in the future. 
Figure 19: Sectoral contribution to total tourism jobs, 2014 (\%)

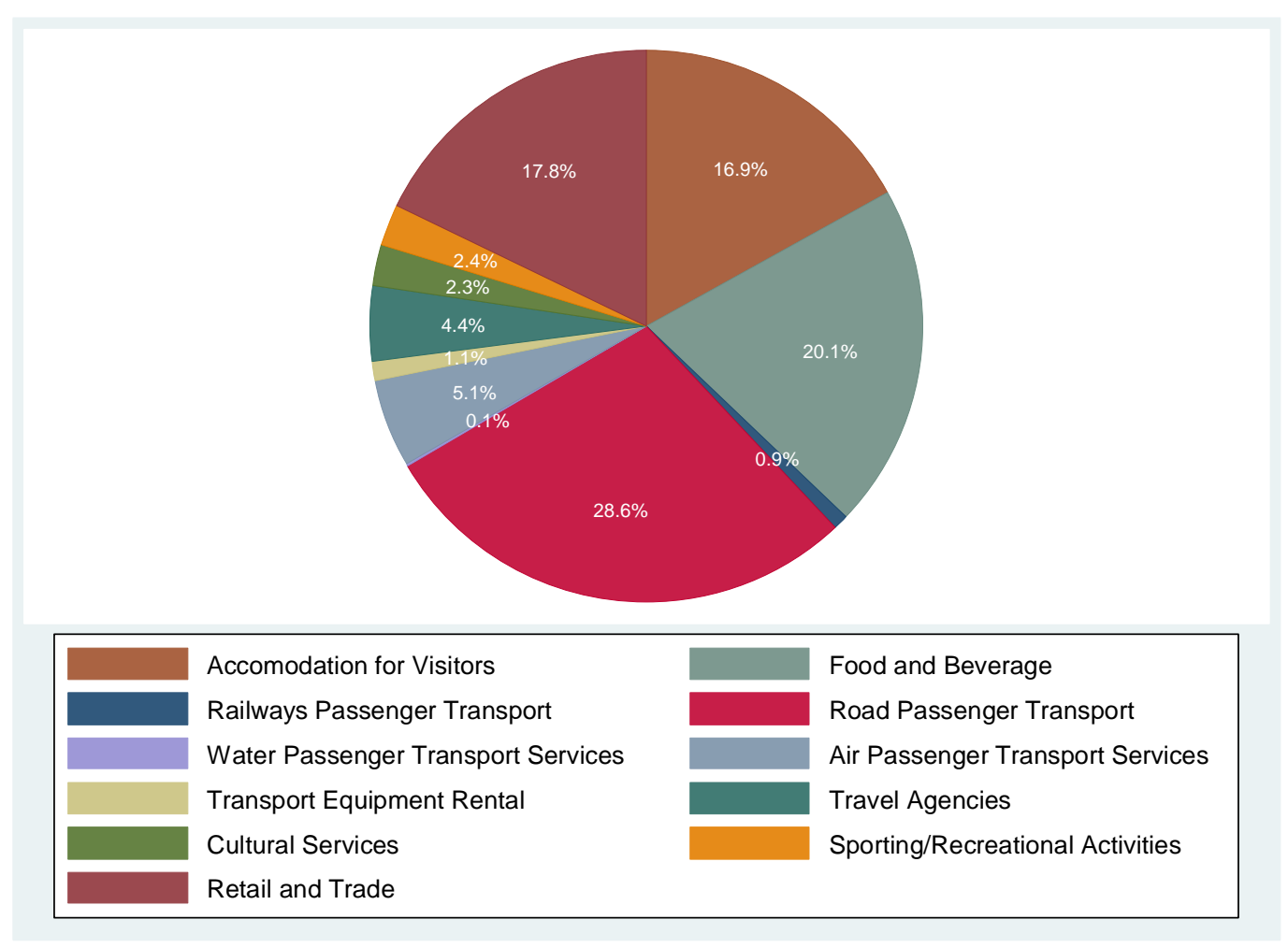

Source: Authors' calculations based on Statistics South Africa (2015a).

Tourism as a mechanism for inclusive growth

Growth in tourism-related employment would be limited in its effectiveness if it excluded many individuals from benefiting from the tourism boom. In a country such as South Africa, with its high level of inequality and unemployment, this is especially pertinent. Any new job opportunities that can have a substantial, positive effect on the marginalized in South Africa should be embraced.

One prominent feature of the South African tourism industry is the spatial dispersion of tourism activities. While other industries (e.g. finance or manufacturing) are concentrated in the major metropolitan areas such as Cape Town or Durban, tourist towns are spread across South Africa. For example, a tourist in Cape Town could also visit towns along the Garden Route such as Hermanus, George, Knysna, and Plettenburg Bay. In Johannesburg, tourists would have the opportunity to visit the Cradle of Humankind in Maropeng, as well as Sun City in the relatively proximate North West province. Along the east coast of South Africa, tourists can visit seaside towns such as St Lucia in the north, and all the way south to rural seaside villages in the Eastern Cape such as Coffee Bay.

A second feature of tourism in South Africa is the high proportion of females and youths involved in tourism-two key demographics of interest in the labour market. Approximately 62 per cent of tourism-related jobs are occupied by females - significantly higher than the overall proportion of jobs occupied by females (45 per cent) (WTCC 2014). By 2023, forecasts suggest that women will comprise 68 per cent of tourism-related jobs-an increase of 6 per cent in 10 years (WTCC 2014). Around 11 per cent of tourism jobs are occupied by youths (15-24)slightly higher than the overall proportion of jobs occupied by youths (8 per cent). In 
comparison to other major sectors, tourism has the second-highest proportion of youth employed, after manufacturing.

While organizations such as the United Nations World Tourism Organization have identified tourism as a sector that can produce pro-poor growth (Saarinen et al. 2013), there has been a paucity of South African research on the subject. Nevertheless, a recent study highlights the two aforementioned features of the South African tourism market, and demonstrates how tourism can act as a vehicle for socio-economic development.

Butler and Rogerson (2016) conducted qualitative interviews with predominantly black, female employees in Dullstroom, Mpumalanga. Dullstroom is a small town primarily known for its flyfishing and agri-tourism. The interviews revealed that while many of the jobs were unskilled and low paid, they were both permanent and secure, with many employees having had a job for a decade or more. Furthermore, some employees were afforded the opportunity to improve their skills through employers paying for their training. As a result, some employees were promoted to supervisors and managers, which increased their salary and standard of living. Without tourism, these individuals would neither have a job, nor would they have the opportunity to advance their skills.

Overall, there is strong evidence to suggest that the tourism industry can be a driver of employment growth in the future. Despite the global financial crisis and the industry being one that competes on a global level, it created 48,000 jobs since 2008. Tourist numbers (both domestic and international) have continued to grow, creating more jobs. Furthermore, many of these jobs are low skilled, located in towns where there is little other economic activity, and have a higher-than-average representation of women and the youth. In addition, as Butler and Rogerson (2016) find, there are also opportunities for employees to increase their skills and their wages, so that they do not remain in a low-wage, low-productivity wage cycle. For tourism to continue as a source of employment growth, there needs to be strong security, political stability, and the removal of onerous travel regulations which make it difficult to enter South Africa.

Santana-Gallego et al. (2016) show that for every 1 per cent increase in the ratio of terrorist attacks per 10,000 people, tourist arrivals immediately drop by 2.3 per cent and by 1.74 per cent the year after. Although the probability of a terrorist attack in South Africa is low, the study does indicate that tourists place great importance on security. In South Africa, common crimes against tourists are muggings and robberies. Although such crimes do not attract the degree of international media attention given to terrorist attacks, they can still affect the country's image if the attacks are perceived to be more commonplace than other competing destinations.

In mid-2014, the Department of Home Affairs introduced new visa regulations to reduce child trafficking (Oxford Business Group 2015). The regulations were onerous in that they required all children who were under the age of 18 and entering South Africa to have an unabridged birth certificate. In addition, for countries in which a visa is required to enter South Africa, parents had to appear in person during the application process to obtain the new biometric visa (Oxford Business Group 2015). It was estimated that the immediate impact of the regulations would see South Africa losing R4.1 billion in service exports and 9,300 tourism-related jobs (Oxford Business Group 2015). Furthermore, business bookings were down by between 40 and 70 per cent. In response, the government has eased some of these regulations (Hartley and Phakathi 
2015). However, it remains difficult to predict whether this regulatory error will have any longterm impact on South African tourism. ${ }^{19}$

South African tourism is a key services sector, as its contribution to GDP and employment show. Although employment is somewhat volatile, it is a key contributor in three aspects. Firstly, the industry provides job for individuals across the skills distribution, and in many senses is a key generator of unskilled jobs, and possibly small, micro, and medium enterprise jobs. Secondly, tourism has a unique spatial component, where jobs are created in economically underdeveloped, but pristine and tourist-friendly areas. Thirdly, the industry's propensity to generate employment opportunities for women and youth indicates that the industry is able to promote a more inclusive form of growth. In order to grow, however, challenges such as security and regulations must be addressed.

\subsection{Agri-processing as a source of inclusive export-driven growth in South Africa}

Another industry that has the potential to drive inclusive export-driven growth is that of agriculture-particularly processed agriculture and high-value horticulture. As such, in this section we examine the growth potential of agriculture exports in South Africa. Agriculture is a unique instrument for development in that it plays an important role in raising the incomes of the rural poor and supporting inclusive growth (Pieterse et al. 2016). This is realized through the sector's ability to create rural jobs, support rural livelihoods, and offer food security for smallscale farmers. In addition, the sector generates positive spillovers resulting from its strong linkages with the rest of the economy (e.g. logistics services). The agriculture sector, especially the processing and high-value horticulture sub-sectors, has the potential to generate exportdriven growth.

\section{Composition and growth performance of agri-processing exports}

In this sub-section, we consider the composition and performance of South African agricultural exports over the period 2000 to 2014. In Table 8, we provide measures of the composition and growth of South African exports, with agricultural exports disaggregated according to the Regmi et al. (2005) definitions of bulk, horticulture, processed, and semi-processed products. ${ }^{20}$

\footnotetext{
${ }^{19}$ No data currently exists to determine the impact of the regulatory error on tourist arrivals. It is reasonable to assume, however, that South Africa's image as a tourist destination suffered during this period, as it created an unnecessary, additional hurdle to enter South Africa.

${ }^{20}$ Consistent with that applied in Fukase and Martin (2016).
} 
Table 8: Composition and growth of South African exports, 2000-14

\begin{tabular}{|c|c|c|c|c|c|c|c|c|}
\hline & \multicolumn{2}{|l|}{ Share } & \multirow{2}{*}{$\begin{array}{l}\Delta \text { Share } \\
2000- \\
14\end{array}$} & \multirow{2}{*}{$\begin{array}{l}\text { Growth } \\
\text { Avg. p.a. }\end{array}$} & \multirow{2}{*}{$\begin{array}{l}\text { Intensive } \\
\text { margin }\end{array}$} & \multicolumn{3}{|c|}{ Extensive margin } \\
\hline & 2000 & 2014 & & & & Dying & Destination & Product \\
\hline $\begin{array}{l}\text { Mining } \\
\text { Agriculture }\end{array}$ & 29,7 & 28,8 & $-0,9$ & 6,8 & 73,0 & $-4,8$ & 31,8 & 0,0 \\
\hline Bulk & 0,7 & 0,7 & 0,0 & 7,3 & 57,5 & $-18,1$ & 60,3 & 0,2 \\
\hline Horticulture & 2,8 & 3,6 & 0,7 & 8,5 & 94,4 & $-0,9$ & 6,5 & 0,0 \\
\hline Processed & 5,4 & 4,3 & $-1,1$ & 5,4 & 85,1 & $-9,8$ & 23,3 & 1,4 \\
\hline $\begin{array}{l}\text { Semi- } \\
\text { processed } \\
\text { Manufacturing }\end{array}$ & 2,1 & 2,1 & $-0,1$ & 6,8 & 74,1 & $-15,7$ & 41,5 & 0,1 \\
\hline Pure & 32,2 & 31,7 & $-0,4$ & 6,9 & 82,1 & $-11,6$ & 29,5 & 0,0 \\
\hline $\begin{array}{l}\text { Resource- } \\
\text { based }\end{array}$ & 26,9 & 28,7 & 1,8 & 7,4 & 44,0 & $-6,4$ & 60,7 & 1,7 \\
\hline Total & 100 & 100 & & 7.0 & 68,5 & $-7,8$ & 38,7 & 0,6 \\
\hline
\end{tabular}

Note: 1 . The intensive margin refers to the intensification of existing trade relationships. 2. 'Dying' refers to the ending of a trade relationship. 3. 'Destination extensive margin' refers to entry into new destination markets. 4. 'Product extensive margin' refers to entry into new product markets. 5 . Shares in columns 2 and 3 do not sum to 100 due to a small amount/number of uncategorized products.

Source: Authors' calculations using trade data from the UN COMTRADE WITS dataset (UNCOMTRADE n.d.).

Looking at the composition of South African exports, with emphasis on agriculture exports, a number of key points emerge. Firstly, on aggregate, agricultural exports comprise a tenth of total exports and this has remained stable over the period 2000 to 2014. This is interesting because despite declining employment and GDP shares, the export shares of the sector have remained robust. This suggests that the strong commercial presence in the sector has retained its competitiveness in the global market. ${ }^{21}$

Secondly, it is worth noting that agricultural exports are relatively small compared to mining, pure manufactures, and resource-based manufactures. ${ }^{22}$ This does suggest that these 'smokestack' industries are likely to remain important components of South Africa's long-term growth trajectory. However, this does not dissuade from the importance of service industries that ultimately allow for the efficient functioning of these 'smokestack' industries (e.g. logistics services are key to moving manufactured and mining products from the factory gate to the export destination).

Thirdly, it is evident that processed and horticulture exports comprise the highest shares of agriculture exports. ${ }^{23}$ Based on the analysis in Fukase and Martin (2016), the composition of agricultural exports in the South African export portfolio is more in line with global levels than those in Sub-Saharan Africa, where bulk agriculture exports are more prominent. This is consistent with South Africa's middle-income country status. Fukase and Martin (2016) show that higher ratios of processed agriculture to total agriculture are associated with higher levels of development. This does suggest that the South African agriculture industry is well placed to

\footnotetext{
${ }^{21}$ Pieterse et al. (2016) show that labour productivity in South Africa's agriculture sector is highest among its emerging market peers.

22 'Pure manufactures' refer to manufactured products with marginal natural resource content.

23 The top 20 agriculture products exported by South Africa are comprised of: horticulture products, such as oranges, grapes, apples, pecan nuts, pears, mandarins, grapefruit and lemons; processed agriculture products, such as wine, frozen fish fillets, food preparations, and meat from bovine animals; and semi-processed products, such as cane sugar and shorn wool. See Table A3 in the Appendix for more information.
} 
exploit export opportunities pertaining to high-value horticulture and relatively sophisticated processed agriculture products.

In terms of growth, bulk ( 7.3 per cent) and horticulture (8.5 per cent) exports have outperformed aggregate export growth (7 per cent) in South Africa over the period 2000 to 2014, while processed (5.4 per cent) and semi-processed (6.8 per cent) exports have underperformed. This is reflected in the changes in export shares across these four product groupings. Of all the product groupings, high-value horticulture exports have grown the fastest over the period-8.5 per cent per annum. Pieterse et al. (2016) note that despite the relative robustness in export performance in agricultural exports, South Africa has underperformed relative to its emerging market peers in terms of growth rates.

In Table 8, we decompose export growth across each of the product groupings into intensive and extensive margins. The relatively rapid growth in horticulture products is driven by the intensification of existing export relationships. In addition, the exiting out of export relationships —dying export relationships - is much smaller for horticulture products than other agriculture products. This is consistent with Besedes and Prusa (2011) who argue that the deepening and survival of export relationships is important to achieving high export growth rates.

In terms of entry into new export markets, it is evident that entry into new destination markets is relatively important for bulk, processed, and semi-processed agriculture exports. Conversely, entry into new product markets is marginal. Brenton and Newfarmer (2009) argue that the export growth process is more nuanced than the discovery of new products (i.e. product extensive margin), and the policy aimed at facilitating export growth must take cognizance of this. They show that the entry into new destination markets, and the intensification of these export relationships, are key channels of export growth. As such, associated industrial policy needs to facilitate the process of entry into new markets by reducing the fixed and variable costs associated with entry (see Melitz 2003). At the same time, policy needs to ensure that the business environment is as stable as possible in order to allow the survival and deepening of export relationships linked to agricultural products.

\section{Regional composition of agriculture exports}

Figure 20 shows the regional breakdown of agricultural exports by product category. The major sources of demand for South African agriculture are spread across developing countries in SubSaharan Africa (26.4 per cent), the East Asia \& Pacific region (17.4 per cent), and developed countries in Europe (37.8 per cent).

Developed countries in Europe are the main sources of demand for horticulture (52.4 per cent) and processed agriculture (36.6 per cent) products. This is consistent with the notion that the demand preferences of high-income markets are in favour of products that embody increasingly more value-added services. Conversely, the main source of demand for lower value-add bulk agriculture products are countries in Sub-Saharan Africa (44.8 per cent) and East Asia and Pacific (28.4 per cent). 


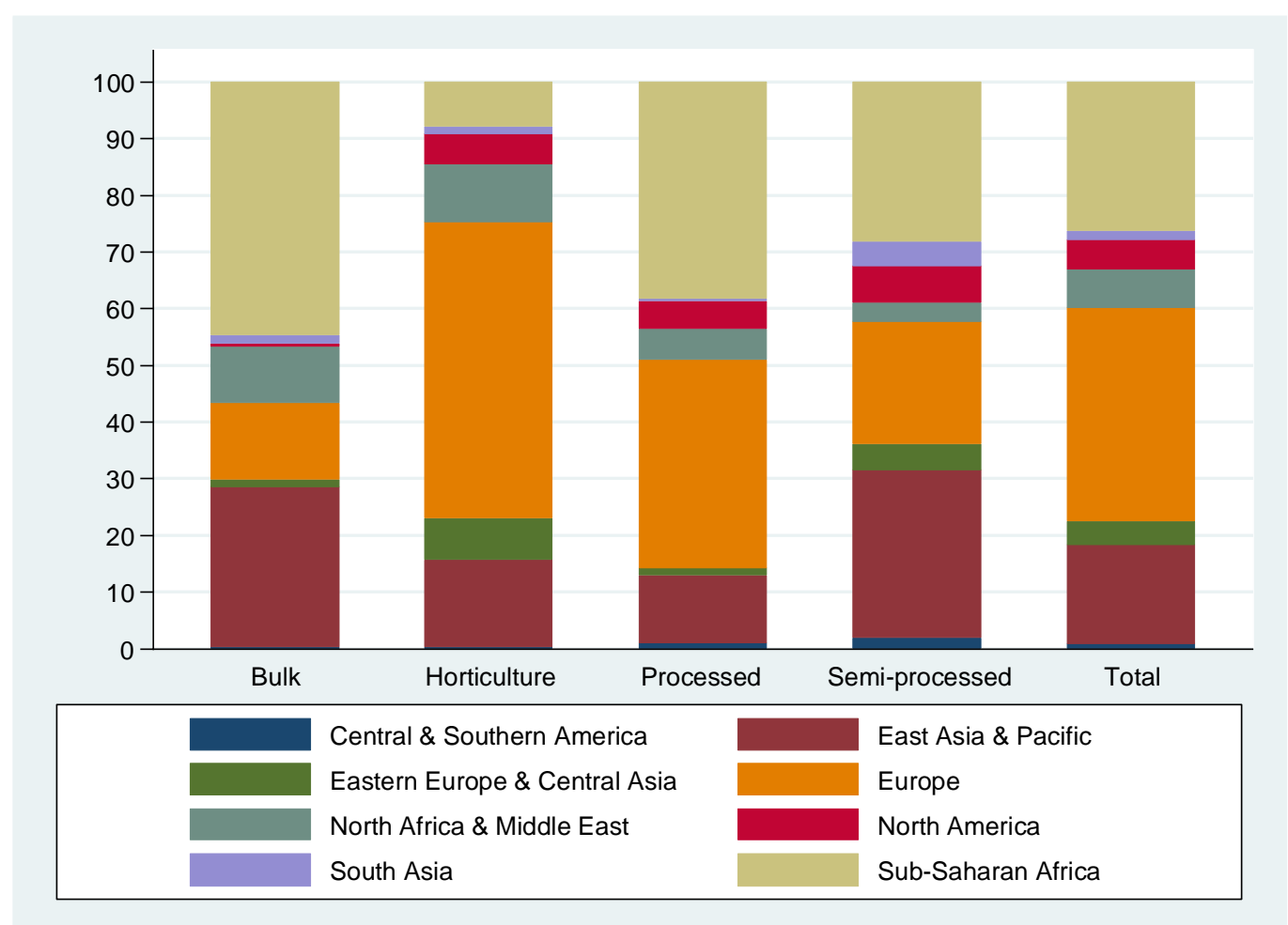

Source: Authors' calculations using trade data from the UN COMTRADE WITS dataset (UNCOMTRADE n.d.).

\section{Competitiveness of agriculture exports}

In Table 9 we consider the competitiveness of South African agriculture exports in global markets by examining the RCA of its agriculture exports. ${ }^{24}$ The top panel shows the RCA for total agriculture exports, and the agriculture exports by product grouping. The bottom panel shows the number of agriculture products with a RCA greater than 1 on aggregate, and by product grouping. The measures for South Africa are presented in comparison to other African countries of interest.

It is evident in Table 9 that all but one African country (Nigeria) has a RCA in agriculture. South Africa has the lowest RCA measure for total agriculture exports (1.1), while the RCA measures for the other African countries are well in excess of unity. Consistent with Fukase and Martin (2016), who show that African countries tend to have higher shares of bulk agriculture exports in total agriculture exports, the RCA measures for bulk agriculture are highest across the sample of African countries. The only product grouping for which South Africa has a RCA are horticulture products. Although, an RCA of 0.9 for processed and semi-processed products suggests it is close to having a revealed comparative advantage in these products. Conversely, it is evident that across most agriculture product groupings, the sample of African countries have a RCA.

The RCA measures in the bottom panel show that the aggregate RCA measures hide some of the detail. Although South Africa has the lowest (other than Nigeria) RCA measures on

\footnotetext{
${ }^{24}$ Revealed comparative advantage is measured as the share of product A in total South African exports, relative to the share of world exports of product A in total world exports. An RCA index above 1.0 indicates that a country's share of exports in a sector exceeds the global export share of the same product.
} 
aggregate and for the broad agriculture product groupings, it has the greatest number of agriculture products with a RCA greater than one (176 products). These products are mainly characterized as horticulture ( 34 products), processed ( 82 products), and semi-processed (52 products). This does suggest that the South African agriculture industry is globally competitive in higher value-added agriculture industries.

Table 9: Revealed comparative advantage indices by sub-sector in agriculture, 2014

\begin{tabular}{|c|c|c|c|c|c|}
\hline & Bulk & Horticulture & Processed & Semi-processed & Total \\
\hline \multicolumn{6}{|c|}{ RCA measure by agriculture sub-sector } \\
\hline Ethiopia & 18,6 & 20,6 & 0,5 & 4,6 & 6,6 \\
\hline Ghana & 14,5 & 3,2 & 0,7 & 3,6 & 3,9 \\
\hline Kenya & 13,3 & 18,8 & 2,0 & 1,3 & 5,5 \\
\hline Mozambique & 4,6 & 1,4 & 0,4 & 1,9 & 1,6 \\
\hline Nigeria & 0,6 & 0,2 & 0,1 & 0,1 & 0,2 \\
\hline Rwanda & 12,8 & 0,2 & 0,6 & 3,7 & 3,3 \\
\hline Senegal & 2,6 & 5,9 & 5,9 & 1,4 & 4,2 \\
\hline Tanzania & 12,1 & 5,8 & 2,2 & 5,1 & 4,9 \\
\hline Uganda & 28,0 & 6,4 & 2,8 & 3,0 & 7,3 \\
\hline South Africa & 0,4 & 3,5 & 0,9 & 0,9 & 1,1 \\
\hline \multicolumn{6}{|c|}{ Number of products with $\mathrm{RCA}>1$} \\
\hline Ethiopia & 14 & 33 & 18 & 28 & 93 \\
\hline Ghana & 4 & 15 & 32 & 23 & 74 \\
\hline Kenya & 13 & 32 & 64 & 55 & 164 \\
\hline Mozambique & 13 & 10 & 21 & 27 & 71 \\
\hline Nigeria & 2 & 2 & 8 & 9 & 21 \\
\hline Rwanda & 9 & 5 & 41 & 28 & 83 \\
\hline Senegal & 13 & 21 & 82 & 41 & 157 \\
\hline Tanzania & 27 & 21 & 55 & 60 & 163 \\
\hline Uganda & 23 & 35 & 59 & 51 & 168 \\
\hline South Africa & 8 & 34 & 82 & 52 & 176 \\
\hline
\end{tabular}

Note: The top panel shows the RCA for all agriculture exports (column 5), and for agriculture product groupings (columns 2 to 4). The bottom panel shows the number of HS6 products that have a RCA greater than one.

Source: Authors' calculations using trade data from the UN COMTRADE WITS dataset (UNCOMTRADE n.d.).

In light of the analysis of South Africa's agriculture exports, a number of implications arise. Firstly, there is greater growth potential for processed and horticulture products than bulk agriculture products, which South Africa is well positioned to exploit. Developed country markets such as Europe tend to demand higher value agriculture products and food stuffs, while developing country markets, particularly those in Africa, are likely to experience rising incomes in the future and thus shift to processed foodstuffs. Secondly, the labour-intensive nature of horticulture indicates that there is potential to generate employment-intensive export-driven growth. Given the labour-intensive nature of this growth, it is likely to be more inclusive. Thirdly, it is likely that growth in this sector can generate positive spillovers into associated economic activities such as transport and logistics, packaging, irrigation equipment maintenance, and other linked manufacturing and service activates (Pieterse et al. 2016).

\subsection{Expanding the market: opportunities in the Rest of Africa}

The analysis of service exports in Section 5.1 omits an important element of South Africa's service exports. Data on service exports from the World Bank's Trade in Services Database (World Bank 2016b) only measures Modes 1 and 2 (see Box 1) and thus omits an important 
source of services trade-Mode 3 or FDI. There are a number of South African companies that have successfully entered the global market. ${ }^{25}$ An investigation of outward-bound FDI from South Africa, particularly that derived from service-orientated firms, allows for a more complete picture of the export potential of South African firms. Therefore, in this section we start by examining aggregate trends in South African FDI by region, with emphasis on FDI into Africa. This is complemented by a case study analysis of three South African service sector firms that have successfully entered the global marketplace: Shoprite, MTN, and Netcare.

\section{South African foreign direct investment}

One of the attractions of services for developing countries is their export potential. Service-based companies who have established themselves in their 'home' country often invest in other countries, primarily to boost growth. Although FDI outflows are from private companies, they are seen as a representation of their home country. If these companies are successful in foreign countries, other foreign companies might be interested in doing business with them, leading to greater growth. In what follows, we examine the levels (stock measure) of FDI by South African companies. ${ }^{26}$

Figure 21: Total FDI stock outflow and average annual growth rate, 2001-12

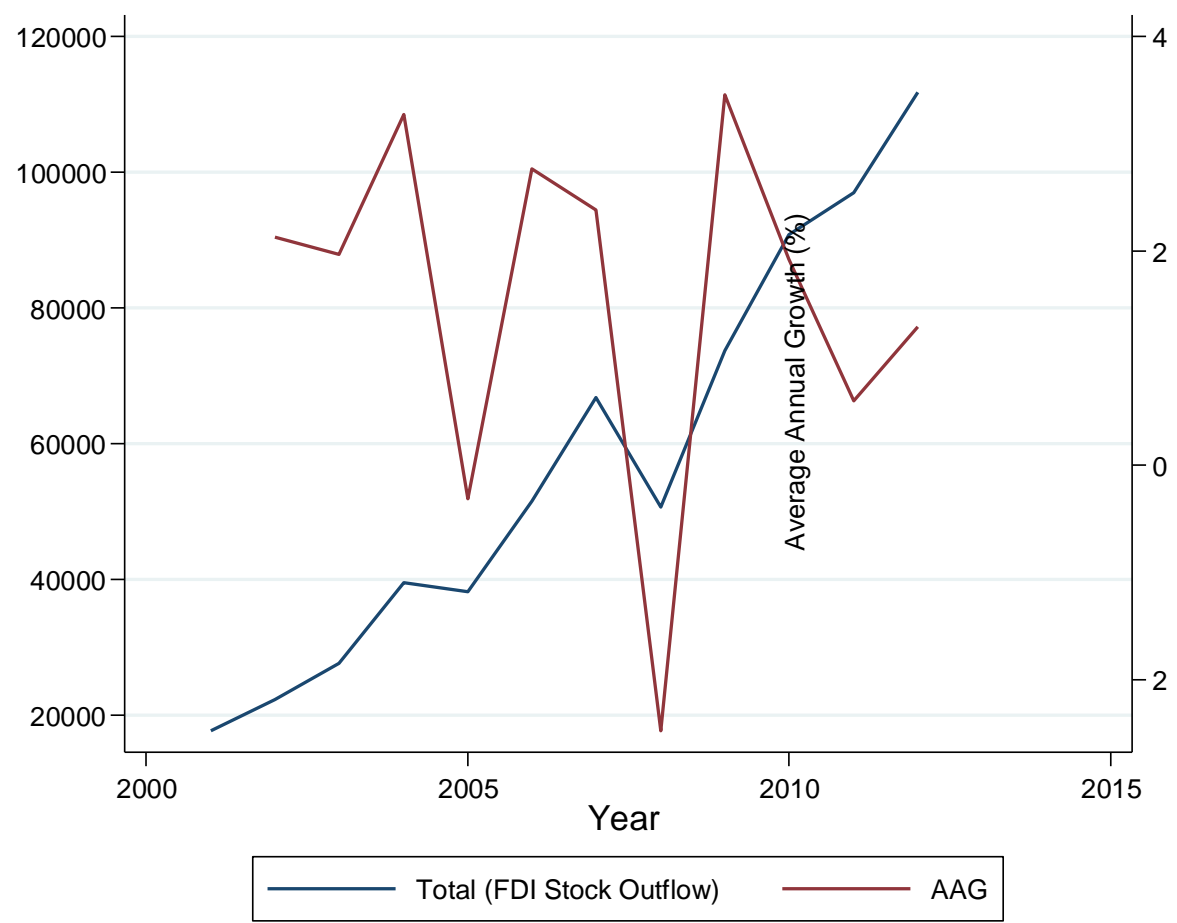

Source: Authors' calculations based on UNCTAD (2014).

\footnotetext{
25 The Forbes Global 2000 list of top companies in 2016 contains the following South African firms that are services orientated (ranking in brackets): Standard Bank Group (317), Steinhoff International (440), FirstRand (502), MTN Group (523), Naspers (680), Sanlam (725), Bidvest Group (1,062), Shoprite Holdings (1,497), Remgro Limited (1,529), Aspen Pharmacare Holdings (1,590), MMI Holdings (1,652), and Rand Merchant Bank Holdings $(1,897)$.

${ }^{26}$ FDI stock is defined as the accumulated investment in a particular country.
} 
In Figure 21, we examine the total FDI stock outflow from South Africa (blue line, left y-axis) and its associated average annual growth rate (red line, right y-axis) between 2001 and 2012. In 2001, South African companies had assets worth US $\$ 17,751 \mathrm{~m}$ overseas. FDI stock abroad increased substantially to US $\$ 111,780 \mathrm{~m}$ by 2012 - an increase of over 500 per cent. This indicates that South African companies have become bold in investing in new markets. Furthermore, this might also indicate the desire for South African companies to diversify their revenue streams, given saturation in the domestic market.

The average annual growth rate graph indicates that there is substantial volatility in FDI stock outflows. For example, in 2004, FDI stock outflows increased by 3.3 per cent from the previous year, but subsequently retracted by 0.3 per cent the following year. This pattern is repeated between 2007 and 2009. In 2007, growth of 2.4 per cent is recorded, followed by a retraction of 2.5 per cent, and then growth of 3.5 per cent. This volatility can be explained by the small number of South African firms investing outside of South Africa. South Africa does not have a large number of big companies investing abroad, so a decision to disinvest from a foreign country or countries by one company will have a large effect on FDI stock outflows. Furthermore, the nature of the decision is important. When a company decides to disinvest, it usually closes all its infrastructure as fast as possible to minimize losses. In contrast, when a company is investing in a new country, the process is gradual, with incremental investments.

We now consider the regional composition of South African FDI outflows. In Figure 22, it is evident that between 2001 and 2005, more than 90 per cent of FDI outflows were directed toward countries outside of Africa. The bulk share of these outflows were directed toward developed economies, particularly in Europe. Many established South African companies have access to networks and capital in various European economies, hence the shift into Europe is not surprising. However, this has not prevented many other corporates from entering into emerging markets. For example, Naspers is heavily invested in the Chinese technology company, Tencent. Sanlam partnered with Shriram Group to create a life insurance company in India, in 2006.

However, since 2006, South African companies have increasingly turned to Africa: the proportion of FDI in Africa has more than doubled from 8 to 17 per cent. However, growth has slowed, with FDI stocks in Africa having only grown by 4 per cent between 2006 and 2012 . Nevertheless, the relative share of FDI in African countries in 2012 is triple that in 2001. This indicates that an increasing number of South African companies see Africa as a key growth frontier. 


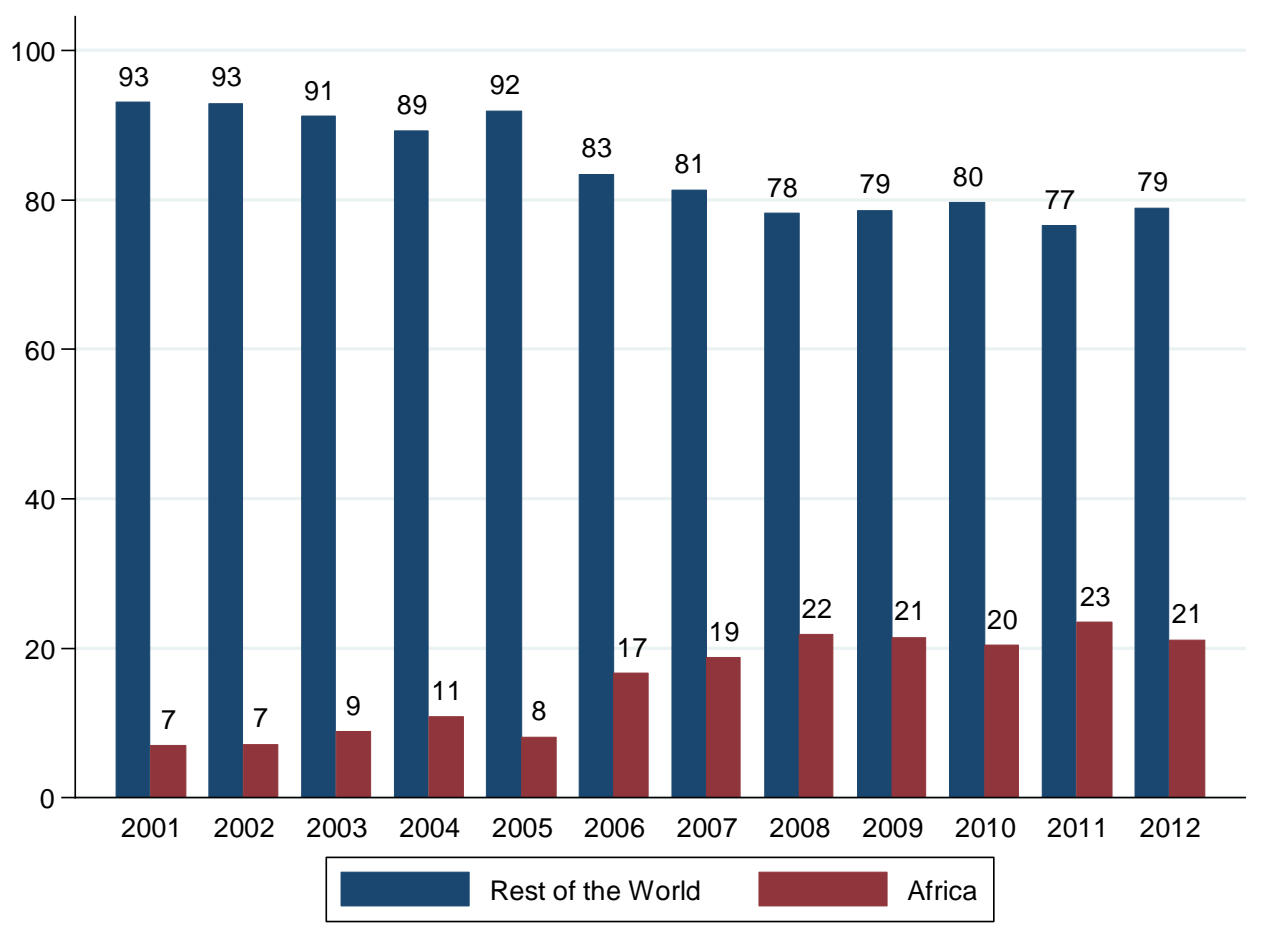

Source: Authors' calculations based on UNCTAD (2014).

In Figure 23, we examine the levels of FDI in different African regions: North and West Africa (blue line), East Africa (burgundy line), and Southern Africa (green line). In 2001, Southern Africa comprised 47 per cent of South African FDI in Africa, but that rose to 73 per cent in 2002, and declined slightly to 69 per cent in 2003. However, that proportion has declined rapidly, reaching a low of 14 per cent in 2007, but subsequently recovered to 29 per cent in 2012. The big investments in Southern Africa in 2001-03 are a reflection of the proximity of these markets to South Africa. It is easier to invest in markets which are closer to the 'home' country in terms of logistics, supply chain management, etc. The relative decline since 2003 is not due to disinvestment from Southern African countries-absolute investment has increased by 12 times in Southern Africa-it is simply that other regions, particularly East Africa, have grown at a faster rate over the same period.

In 2001, 53 per cent of South African FDI in Africa was invested in East Africa. However, between 2002 and 2005, this dipped to a low of 26 per cent. In 2006, it increased substantially to 65 per cent, and in the last five years has stabilized at between 50 and 53 per cent. The majority of FDI in East Africa is due to investment in Mauritius, which accounts for 91 per cent of investment from South African firms. The attractiveness of Mauritius as an investment destination is due to political stability, a low corporate tax rate (15 per cent compared to 28 per cent in South Africa), and an abundance of professionals (Stones 2015). Investment in Kenya, Uganda, and Tanzania has also increased, but because these increases were off a low-base, their relative contribution is insignificant. 


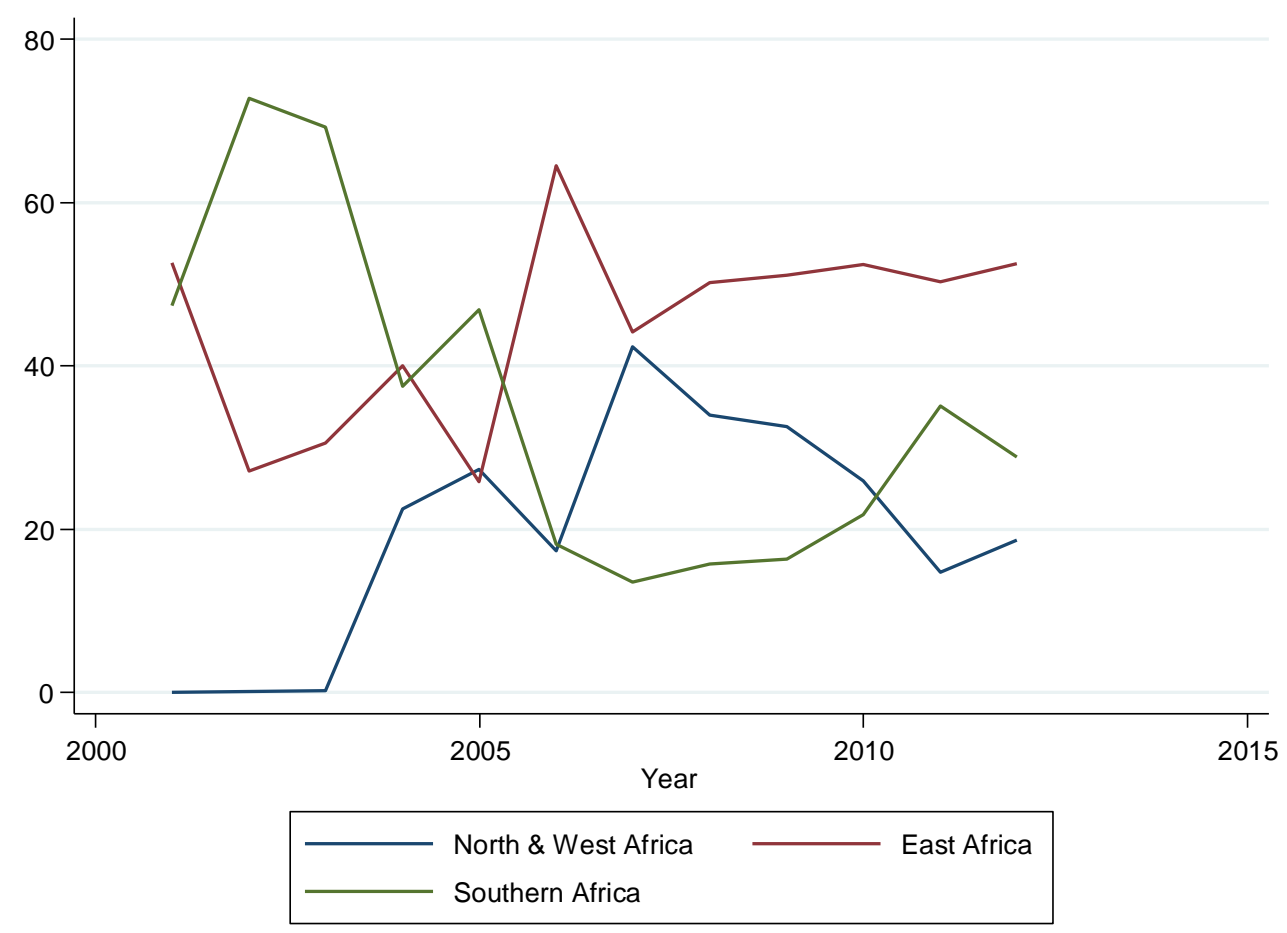

Note: North and West Africa: Egypt, Libya, Ghana, Nigeria, Liberia; East Africa: Kenya, Madagascar, Mauritius, Uganda, Tanzania and Seychelles; Southern Africa: Angola, Botswana, Malawi, Namibia, Swaziland, Zambia, and Zimbabwe.

Source: Authors' calculations based on UNCTAD (2014).

Between 2001 and 2003, there was no investment in North and West Africa by South African companies. ${ }^{27}$ In 2004, South African companies made investments worth US\$906 million in Nigeria. Over the following three years, Nigeria continued to act as a base for South African companies in West Africa, with investments reaching a record US\$4,469 million in 2007. However, the amount of investment in Nigeria has halved since 2009 to US\$2,171 million. Nigeria's relative importance for South African companies has also declined. It attracted 91 per cent of South African investment in North and West Africa in 2007, but this figure only stands at 47 per cent in 2012. This substantial decrease in investment may be partially attributed to the rise of Boko Haram and current political instability. South African FDI in North and West Africa has shifted to Ghana, where its share of FDI into the region rose from 9 per cent in 2007 to 47 per cent in 2012. Indeed, a report from Global Impact Investment Network (2015) shows that between 2005 and 2015, Ghana received 25 per cent of West Africa's 'impact capital', despite comprising only 5 per cent of West Africa's GDP. This reflects the pro-business policies present in this country.

Overall, South African companies have increasingly become globalized, primarily in order to increase revenue streams. Although the substantial majority of investment remains in places outside of Africa_-specifically Europe_there has been substantial growth in Africa since 2001.

\footnotetext{
${ }^{27}$ This might be as a result of data issues. However, much of North and West Africa is also French-speaking. As a result, this region attracts many investors from France and other Francophone countries. Furthermore, North Africa has its own domestic corporations which are equally as strong as South Africa's.
} 
The composition of investment into the different African regions has changed. Initially, the bulk of investment was directed to other Southern African countries, but over time, this has shifted to East Africa, particularly Uganda, Tanzania, and Kenya. There has been growth in North and West Africa, but due to the constant political risks posed in the region, investment by South African companies has been far lower than in East and Southern Africa.

We now turn our attention to three South African service sector companies that have successfully entered the global marketplace, two of which have focused their efforts in Africa.

\section{Case study of South African firms in the global marketplace}

Between the early 1960s and mid-1990s, much of Sub-Saharan Africa ${ }^{28}$ was characterized by civil war and poor governance. As a result, economic stagnation occurred, and policy-makers and academics were pessimistic about Africa's growth prospects. However, consistent growth in the region since the mid-1990s has changed the narrative, with many policy-makers, researchers, and indeed, investors, becoming increasingly optimistic about Africa's future prospects. This was of course evidenced by the data, where between 1998 and 2015, Sub-Saharan Africa recorded for example, an average annualized growth rate of 4.99 per cent-the second-highest region globally after Asia (IMF 2016b).

While many of its less-developed peers experience high rates of economic growth and urbanization, South Africa has seen its economic prospects worsen. Since 2009, it has seen an annual real average growth rate of only 2.3 per cent (SARB 2016), which is only slightly above the population growth rate of 1.8 per cent. ${ }^{29}$ In other words, the average South African has experienced only marginal real income growth over the past six years. The International Monetary Fund (IMF) has sharply revised its 2016 growth projections for South Africa. In October 2015, it projected South Africa to grow at 1.3 per cent in 2016-it is now at 0.1 per cent (IMF 2016a). Africa's most developed economy also has many saturated markets, making it difficult for businesses to grow their revenue. Furthermore, South Africa's proximity to other African markets is a big advantage, both in terms of logistics and supply chain management. Much of the infrastructure is already in place for South African companies to expand into other markets, allowing them to enter markets more quickly and with lower up-front costs than their European, Asian, and North American counterparts.

In light of these factors-high economic growth in key African markets, proximity to these markets, and stagnant growth coupled with market saturation-South African companies have been forced to expand into the Rest of Africa (ROA) and elsewhere, in order to continue growing. We examine three South African services companies-Shoprite, MTN, and Netcarethat have successfully established themselves in foreign markets. These case studies will demonstrate not only that South African companies can succeed in unfamiliar markets, but that the export of services is becoming a key component of the economic growth trajectory of the South African economy.

\section{Shoprite}

The African retail market offers exciting possibilities for South African retailers. It must be noted that 90 per cent of retail trade in African countries is informal (AT Kearney 2015). Informal

\footnotetext{
28 'Africa' is used synonymously with Sub-Saharan Africa.

${ }^{29}$ Data extracted from Statistics South Africa's Mid-Year Population Estimates (Statistics South Africa 2015b).
} 
retail trade refers to street vendors, open-air markets, and kiosks (AT Kearney 2015). This low formal retail penetration rate is in stark contrast to South Africa, where it is estimated that 60 per cent of retail trade occurs in formal settings such as shopping centres (Oxford Business Group 2016). Kenya has the second-highest formal retail penetration rate of 30 per cent, with Nigeria only having half of that (Oxford Business Group 2016). While these low formal retail penetration rates present a challenge for South African companies, they also represent a massive growth opportunity, given the nascent state of formal retail in economies of Africa with large and growing urban populations.

Shoprite-a supermarket retailer-is one of the companies which has aggressively expanded outside of South Africa. Its first foray into the ROA was opening a store in Namibia in 1990 (Shoprite 2015a). Since then, it has expanded into 14 other African countries, including Zimbabwe, Botswana, Nigeria, and Mozambique. This 'Africanization' of the Shoprite brand is evident in Figure 24 below, which estimates the share of revenue and trading profit emanating from Africa (excluding South Africa) since 2010.

Figure 24: Revenue and trading profit in the Rest of Africa (\%), Shoprite

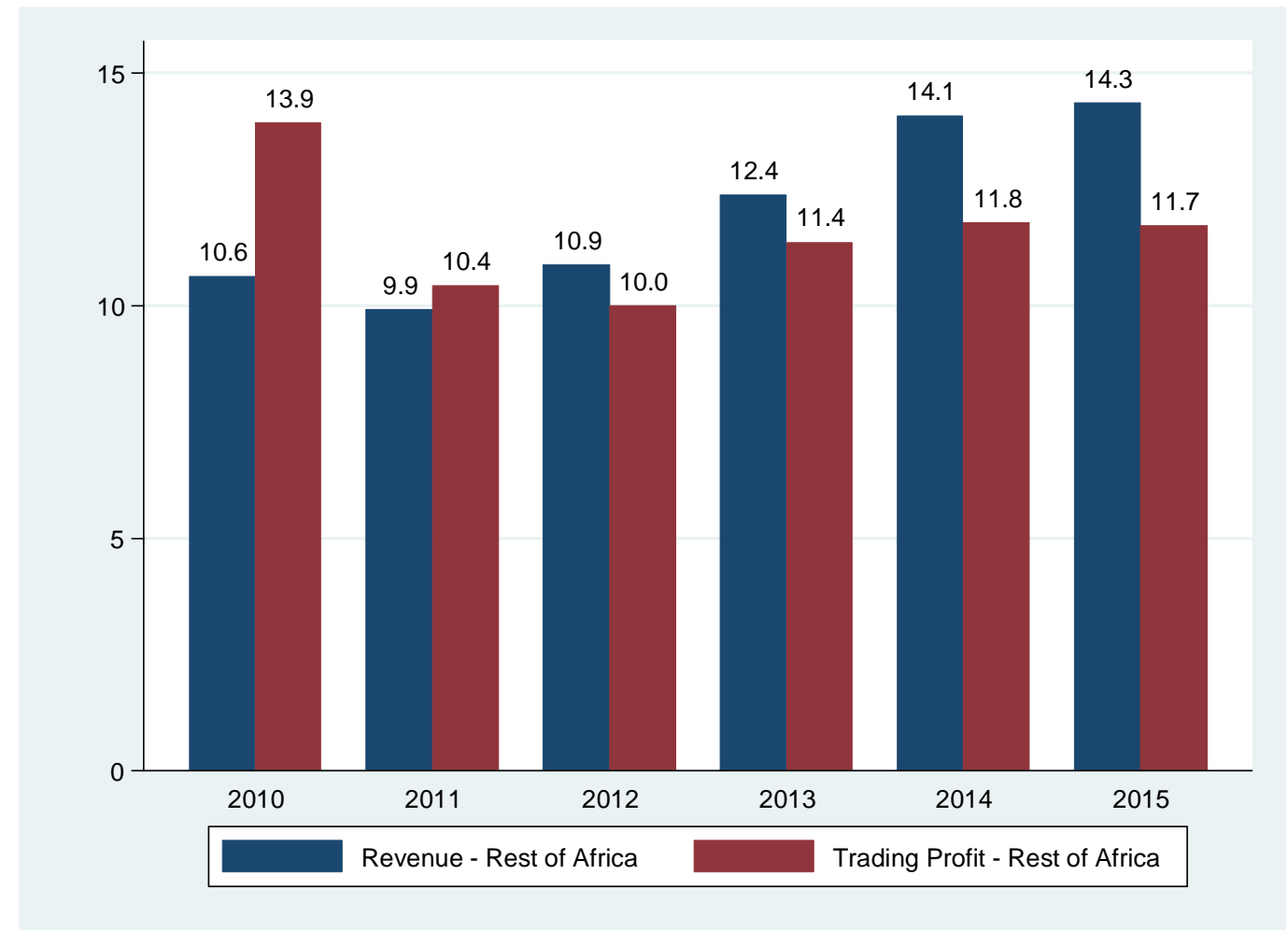

Source: Authors' calculations based on Shoprite (2010, 2011, 2012, 2013, 2014, 2015b).

In 2010, 10.6 per cent of Shoprite's revenue emanated from the ROA, meaning that 89.4 per cent emanated from its South African operations. While the share of total revenue from the ROA declined marginally to 9.9 per cent in 2011, it increased steadily from 10.9 to 14.3 per cent over the period 2012 to 2015 . Overall then, Shoprite saw its revenue base rise by 35 per cent between 2011 and 2015-representing a clear growth of this tradeable service by a South African corporate into the rest of the continent. However, this growth must be understood within the context that South Africa remains the dominant revenue earner for Shoprite. Having said that, the growth in the ROA is suggestive of a growing African market, but note that profit share remained constant between 2011 and 2015, and has in fact dropped from 2010 levels. 
In conclusion, while it is true that the African market offers opportunities for a large, multinational retailer such as Shoprite, for Shoprite these opportunities are not growing in profit share, and remain dominated by their South African operations.

\section{MTN}

In Sub-Saharan Africa there were around 386 million mobile phone users in 2015 (41 per cent penetration rate), which is forecast to grow to 518 million (49 per cent penetration rate) by the end of the decade (GSMA 2015). The percentage of mobile broadband users is expected to increase from 24 per cent to 57 per cent by 2020 (GSMA 2015). The increase in mobile broadband users is mirrored by an increase in smartphones-from 160 million to 540 million by 2020 - an increase of 380 million. The growth in mobile broadband and smartphones is especially pertinent to mobile phone operators who are experiencing a decline in revenue from voice and SMS services as a result of instant messaging applications.

In the same year that democracy became a reality for all South Africans in 1994, MTN began its operations in South Africa as a mobile telecommunications provider. It quickly expanded to other parts of the continent, and by 1998, had acquired licences to operate in Uganda, Rwanda, and Swaziland. MTN has continued to grow and now has operations across 21 countries in three continents-Africa, Europe, and Asia. It is the seventh-biggest mobile operator in the world, with 232 million connections (GSMA 2016).

Table 10 provides a snapshot of MTN's coverage across the world. MTN's market share is fairly high in most countries, as it remains one of the few large mobile networks to disproportionately provide services to the developing world. The data indicates that MTN's market share ranges from 32 per cent in Côte d'Ivoire and Guinea, to total market control in Swaziland. MTN market share data indicates that the company holds an average market share of 50 per cent across the countries that it operates in. Regional averages indicate that MTN's strongest presence is in Southern Africa, where the company has a regional average market share of 59 per cent. However, when the weighted average market share is considered, ${ }^{30}$ West Africa is top, accounting for 41 per cent of MTN's total subscriber base. MTN is still developing market share in Central and East Africa, which is reflected by the levels of the average weighted MTN market share at just over 11 per cent. Note, however, that despite this small share, MTN have over 50 per cent market share in all the countries in this region. A measure of MTN's potential subscriber base, albeit an imperfect one, is reflected in the table as the mobile penetration rate. In Central and East Africa, this is only 66 per cent, representing a potential short-term growth target for MTN.

South Africa has a highly saturated mobile phone market, as indicated by its mobile penetration rate of 170 per cent. In other words, there are 1.7 mobile phones for every one South African. South Africa's neighbours have benefited from their proximity to MTN's home base of South Africa. For example, Botswana has a mobile penetration of 162 per cent, which is only 8 per cent below that of South Africa. Swaziland, in which MTN is the only operator, has a mobile penetration rate of 84 per cent, which is significant considering the widespread poverty in that

${ }^{30}$ A weighted average is constructed by using $\boldsymbol{w}_{i}^{*}=\frac{m_{i}}{M_{i}}$. This is the MTN country base relative to the total MTN subscriber base. The reason one uses a weighted average is to ensure that the total number of MTN subscribers is not ignored at the expense of looking at market share only. 
country. Although Zambia has the lowest mobile penetration rate in the Southern African region (72 per cent), it has the second-highest number of MTN subscribers, after South Africa.

In Central and East Africa, MTN has a similar market share in all four countries. However, mobile penetration rates differ markedly across countries. The Congo has the highest mobile penetration rate ( 85 per cent), followed by Cameroon ( 69 per cent), Rwanda ( 65 per cent), and Uganda (44 per cent). The latter three countries-and especially Uganda-represent potential avenues of growth for MTN, considering that a significant proportion of the population do not yet own a mobile phone.

West Africa represents MTN's most populous region, with 96 million, or 41 per cent of MTN's total subscriber base, residing within this region. Broadly speaking, MTN's market share in this region indicates that it is the dominant player in the market, although there are relatively low market shares in Côte d'Ivoire and Guinea. All countries, with the exception of Guinea Bissau, Liberia, and South Sudan, have a mobile penetration in excess of 70 per cent, indicating a high degree of market saturation in the region. However, there is vast scope for MTN to expand in the three aforementioned countries, particularly in the latter two countries where the majority of the population do not own a mobile phone.

The Middle East, North African, and Mediterranean region contributes 31 per cent toward MTN's total number of subscribers. Given that this is the region most recently entered by MTN, this figure is indicative of the lucrative opportunities presented by the region. Iran is illustrative of this extraordinary growth: Irancell (MTN's subsidiary in Iran) only obtained its licence in 2004, yet in 12 years the number of subscribers is 50 per cent greater than in South Africa. Mobile penetration is also very high at 123 per cent. Overall mobile penetration is relatively high, although Yemen (43 per cent), Afghanistan (53 per cent), and Sudan (67 per cent), are potential growth drivers for MTN in the medium and long term. 
Table 10: MTN's coverage outside of South Africa

\begin{tabular}{|c|c|c|c|c|}
\hline Country & $\begin{array}{l}\text { Number of } \\
\text { subscribers ('000) }\end{array}$ & Market share (\%) & Mobile penetration (\%) & $\begin{array}{l}\text { Weighted average (\%) } \\
\text { of MTN subscribers }\end{array}$ \\
\hline \multicolumn{5}{|c|}{ Southern Africa } \\
\hline Botswana & 1,758 & 52 & 162 & 1 \\
\hline South Africa & 30,588 & 34 & 170 & 13 \\
\hline Swaziland & 995 & 100 & 84 & 0 \\
\hline Zambia & 5,264 & 48 & 72 & 3 \\
\hline Regional & 8,017 & 59 & 122 & 17 \\
\hline \multicolumn{5}{|c|}{ Central and East Africa } \\
\hline Cameroon & 9,178 & 56 & 69 & 4 \\
\hline Congo & 2,250 & 57 & 85 & 1 \\
\hline Rwanda & 4,119 & 55 & 65 & 2 \\
\hline Uganda & 8,929 & 51 & 44 & 4 \\
\hline Regional & 24,476 & 55 & 66 & 11 \\
\hline \multicolumn{5}{|l|}{ West Africa } \\
\hline Benin & 4,012 & 51 & 74 & 2 \\
\hline Côte d'Ivoire & 8,346 & 32 & 109 & 4 \\
\hline Ghana & 16,255 & 52 & 114 & 7 \\
\hline Guinea & 3,244 & 32 & 87 & 1 \\
\hline $\begin{array}{l}\text { Guinea } \\
\text { Bissau }\end{array}$ & 682 & 60 & 64 & 0 \\
\hline Liberia & 1,357 & 68 & 49 & 1 \\
\hline Nigeria & 61,252 & 45 & 79 & 26 \\
\hline South Sudan & 1,200 & 38 & 29 & 1 \\
\hline Regional & 96,348 & 47 & 76 & 41 \\
\hline \multicolumn{5}{|c|}{ Middle East, North Africa and the Mediterranean } \\
\hline Afghanistan & 6,785 & 39 & 53 & 3 \\
\hline Cyprus & 359 & 41 & 105 & 0 \\
\hline Iran & 46,142 & 47 & 123 & 20 \\
\hline Sudan & 8,642 & 34 & 67 & 4 \\
\hline Syria & 5,972 & 42 & 84 & 3 \\
\hline Yemen & 5,351 & 43 & 43 & 2 \\
\hline Regional & 73,251 & 41 & 79 & 31 \\
\hline Total / Avg & 232,680 & 50 & 86 & $100 \%$ \\
\hline
\end{tabular}

Source: MTN (2015).

In looking for the countries which have the biggest growth potential for MTN in the future, it is important to consider three factors. Firstly, mobile penetration should be low, as that indicates there are a vast number of potential subscribers. Secondly, MTN must be dominant as, ceterus paribus, it would enable MTN to obtain the majority of the new subscribers. Thirdly, political risk could impede future growth. MTN operates in three 'high risk' countries: Iran, Syria, and Nigeria. It is possible - as was the case last year when MTN was fined US $\$ 5.2$ billion by the Nigerian regulator and threatened with a revocation of its operating licence-that sudden, unexpected events can happen to companies. Since it is unexpected, companies cannot mitigate such risks, even though such events can have a significant negative impact on them. 
In Figure 25, we look at the percentage of revenue and earnings before interest, taxation, depreciation, and amortization (EBITDA) which originated from Africa (excluding South Africa), for the period 2006 to 2015. For example, in 2006, 52 per cent of revenue originated from the ROA, meaning that 48 per cent was from South Africa. In turn, the share of EBITDA from the ROA (South Africa) was 62 per cent (38 per cent).

Figure 25: Revenue and EBITDA in the Rest of Africa (\%), MTN

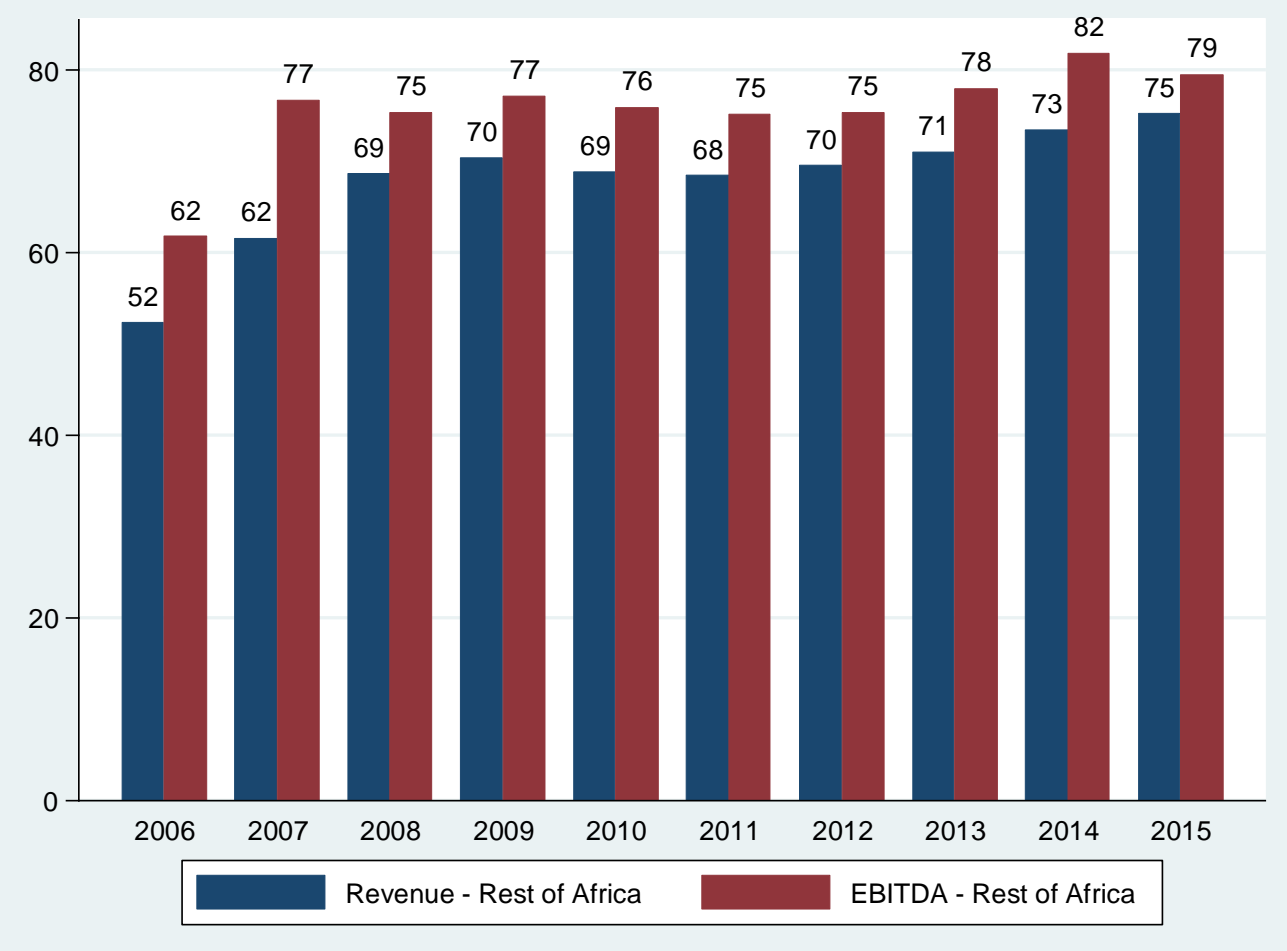

Source: Authors' calculations based on MTN (2006, 2007, 2008, 2009, 2010, 2011, 2012, 2013, 2014, 2015).

Over the period 2006 to 2015, the proportion of revenue from the ROA has increased by 23 per cent, from 52 to 75 per cent. The large jump in revenue between 2006 and 2007, and 2007 and 2008 , was primarily a result of MTN purchasing the Dubai-based Investcom for \$US5.5 billion in 2006, which immediately expanded MTN's coverage from 11 countries to 21, and its subscriber base from 23 million to 28 million (Reed and Guerrera 2006). EBITDA from the ROA rose from 62 per cent in 2006 to 77 per cent in 2007. Since 2007, ROA EBIDTA has remained remarkably stable, reaching 79 per cent in 2015 .

The large proportion of revenue and EBITDA earned from the ROA indicates that MTN has successfully entered other African and Middle-Eastern markets. Indeed, it is extraordinary that MTN South Africa only contributed 25 per cent to overall revenue, considering that MTN entered some of these markets only recently. The growth in revenue and EBITDA between 2006 and 2015 not only suggests a growing African and Middle-Eastern market, but it also suggests a market that is more lucrative in terms of profitability relative to South Africa. However, the growth in revenue and EBIDTA has tapered off in recent years, suggesting market saturation and/or a more competitive environment.

Overall, it is evident that MTN is a company which has taken advantage of the opportunities in Africa and the Middle East to become a global player. MTN operates in 21 countries, making it the second most dominant mobile telecommunications firm (by country spread) in the developing world, after India's Airtel. The direction that MTN has taken can be seen as a growth 
trajectory and path for South Africa—namely through services—at a global level, but focused on developing countries.

\section{Netcare}

Netcare, a private health care services group, was incorporated in 1996 and listed on the Johannesburg Stock Exchange in the same year, beginning with six private hospitals (Netcare 2016). Over the next few years, through acquisitions or the construction of new hospitals, the group increased its asset base to over 40 hospitals. Currently, Netcare owns 57 local hospitals, 70 family medical and dental centres, 14 day centres as well as an emergency medical service (Netcare 2016).

In 2001, Netcare won a R10 million (US\$750,000) contract from the UK's National Health Service (NHS) to manage a cataract facility (Draper et al. 2008). It has completed 12,000 ear, nose, and throat procedures, 300 knee and hip replacements, and won a R30 million (US $\$ 2.2$ million) contract to perform orthopaedic operations (Draper et al. 2008). To fulfil these contractual obligations, Netcare sends South African doctors to the UK for short periods of time. Netcare binds these South African doctors to not seeking employment in the NHS for a further two years after their contract has been completed (Draper et al. 2008). Not only do South African doctors get exposed to a different environment, but they put their new expertize to use back in South Africa-at least in the short term. As with Shoprite and MTN, this example demonstrates the increasing internationalization of service-based industries.

Figure 26: Revenue and profit from the UK (\%) 2006-15

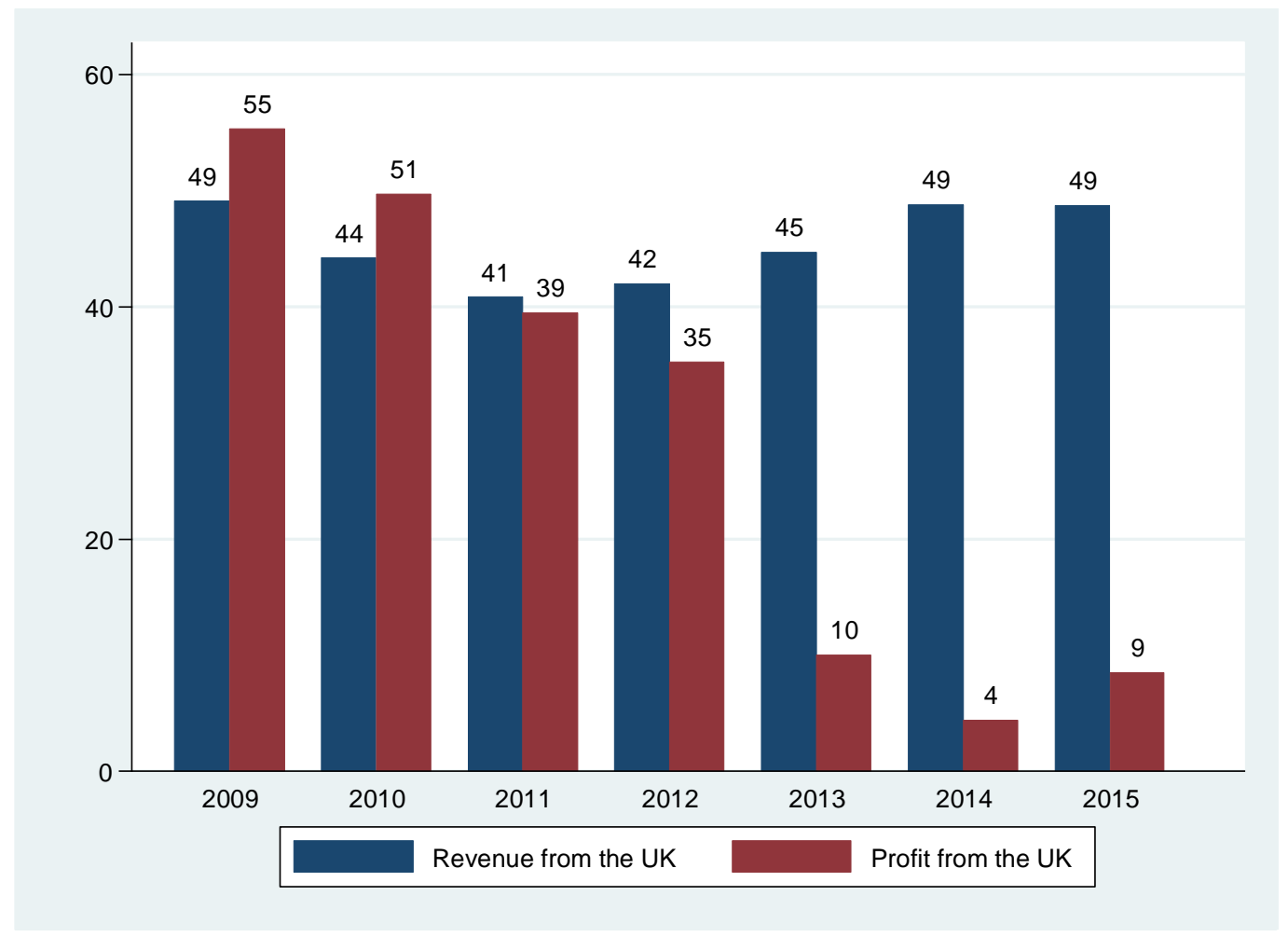

Source: Authors' calculations based on Netcare (2009, 2010, 2011, 2012, 2013, 2014, 2015).

In Figure 26, we scrutinize the proportion of revenue and profit that Netcare obtains from its UK operations. For instance, in 2006, 30 per cent of Netcare's revenue was derived from its UK operations, meaning that 70 per cent came from Netcare South Africa. Similarly, the profit share 
from the UK (South Africa) was 14 per cent (86 per cent). Before we analyse the figures in more detail, there is a caveat: the international financial reporting standards were changed between 2012 and 2013 regarding the calculation of net profit. Therefore, the discussion of profits from UK operations will be in two separate periods: 2009-12 and 2013-15.

Between 2006 and 2007, we observe that the share of Netcare's total group revenue emanating from the UK increased from 30 per cent to 52 per cent, suggesting that the majority of Netcare's income was being generated abroad. This was mainly due to the acquisition of Prime Cure, a medical aid scheme provider, by Netcare in 2006. Subsequently, the proportion of revenue from the UK gradually declined from 52 to 41 per cent in 2011, but rose again, reaching 49 per cent in 2015. This is a significant proportion of revenue, considering the differences between South Africa and the UK in terms of infrastructure. As stated earlier, Netcare's infrastructure in South Africa extends beyond hospitals to primary care centres and emergency response services. In contrast, Netcare's UK operations are limited to hospitals only, of which they own 56-the same as South Africa. However, given the exchange rate differential between the British Pound and the South African Rand, revenues and profits earned in a stronger currency will yield a much higher impact on the Rand-denominated balance sheet of these groups.

Shifting focus to the proportion of operating profit earned by Netcare's UK operations, we notice that in 2006, the operating profit was half that of revenue, suggesting that profit margins were far smaller in the UK than in South Africa. However, after the acquisition of Prime Cure, the proportion of operating profits earned from the UK rose to above 50 per cent of Netcare's overall profit, and exceeded the proportion of revenue from the UK. At its peak, operating profit from the UK accounted for 59 per cent of Netcare's overall operating profit. However, it subsequently declined, and by 2012 only accounted for 35 per cent of Netcare's operating profit. Between 2012 and 2013, Netcare sold a part of its stake in one of its UK operations. This indicates that operating profit from 2013 onwards is not comparable to results before that time. Between 2013 and 2014, the percentage of profit earned from the UK dropped from 10 to 4 per cent, but has since recovered to 9 per cent.

Overall, Netcare's UK business operations remain influential in determining total revenue for the group, unlike Shoprite's ROA operations. Secondly, Netcare uses South African human capitalin the form of South African doctors-for some of their operations in the UK. Evidently, this is a case where South African service 'excellence' exists, rendering it able to make gains in a foreign market.

In summary, we can identify two consistent themes that are present in all three companies investing in non-SA operations. Firstly, revenue earned from non-SA countries is increasing, both in absolute and relative terms. Netcare and MTN are particularly reliant on foreign revenue streams to grow their overall revenue. Secondly, in the sectors in which these three companies operate, there are indications that competition is becoming greater. This is demonstrated through Shoprite's lower profit margin in non-SA supermarkets, MTN's lower subscriber, revenue, and EBIDTA growth (as compared to earlier years), and Netcare's decision to sell a part of its UK operation.

In the next section we look at the extent to which South African policy-makers have recognized the potential of service industries as drivers of future economic growth. 


\section{The policy environment: is the services sector a policy priority?}

The evolution of the services sector as a source of economic growth and structural transformation suggests that the services sector has become an increasingly important element of industrial policy in developing countries (Ghani and O'Connell 2014). Indeed, researchers such as Ghani and O'Connell (2014) encourage developing country policy-makers to approach growth with a broader agenda, instead of focusing narrowly on manufacturing-led growth.

South African policy documents have placed greater emphasis on the development of the services sector in recent years. One of the earliest key policy documents is the Industrial Policy Action Plan (IPAP), originally published in 2007, and updated annually. The plans aim to promote long-term industrialization, as well as diversification away from traditional commodities and non-tradeable services, by expanding into value-added sectors with high employment opportunities. In this regard, the plan concentrates on promoting labour-absorbing goods and services. In the most recent publication, business process services is identified as an industry with high potential. The IPAP detailed an incentive structure created to support growth and increase South Africa's market share as a global destination for offshored business process services.

However, the development of the industry is constrained by a shortage of suitably skilled managers, and increasing competition from other African offshore locations (Department of Trade and Industry 2014). Nonetheless, significantly more attention is paid to the manufacturing sector, which is described as critical to sustainable growth. The steady decline in the percentage that mining, agriculture, and manufacturing contribute to GDP, was labelled problematic. In addition, the services sector growth was said to be 'unsustainable' as it is based on credit extension, retail consumption, and dramatic growth in the security industry (Department of Trade and Industry 2014).

The New Growth Path (NGP), released in December 2010, is in line with the IPAP in most respects. It identified job creation as a major priority, focusing on six areas: infrastructure development, agriculture, mining, manufacturing, tourism, and the 'green economy' (Department of Economic Development 2011). Tourism and high-level business services were predicted to create over 250,000 jobs directly, with more being created in cultural industries such as film, music, and theatre. In order to achieve this, the NGP proposed to strengthen measures to expand tourism infrastructure, improve training, promote targeted marketing campaigns, and identify employment opportunities for the youth (Department of Economic Development 2011). The NGP also detailed a New Tourism Sector Strategy that would 'benchmark pricing, extend quality assurance, and address logistics' (Department of Economic Development 2011). Nevertheless, the bulk of the five-million jobs target was said to rest on reindustrializing the economy with manufacturing contributing most significantly.

The National Development Plan (NDP) was created as a complement to the NGP in 2013, and offers a long-term vision that 'aims to ensure that all South Africans attain a decent standard of living through the elimination of poverty and the reduction of inequality' (National Planning Commission 2013). The report acknowledges that expanding export-orientated industries is critical to creating sustainable job growth, and identified business services and tourism as two areas in which South Africa has a comparative advantage. Where the plan deviates from IPAP and the NGP is that industrial strategy is limited, manufacturing takes a back seat, and services are identified as central for job growth (National Planning Commission 2013).

However, the strategy for growth relies on low-wage, small, domestically orientated services firms, providing largely business, retail, and personal services. These are not the same modern, 
impersonal, IT-enabled services that seem to have driven economic and employment growth in other countries. While the NDP identifies strong growth in the financial sector, this is generally highly sophisticated work that is inaccessible to historically marginalized groups, and is a relatively small employer in relation to its economic contribution. The NDP also targets the promotion of domestically orientated industries where 'global competition is less intense' and there is a high labour component such as housing construction, personal services such as cleaning and hair dressing, and business services such as office cleaning and repair (National Planning Commission 2013). This remains the focus until phase three of the plan from 2023 to 2029, when South Africa will supposedly have built a 'knowledge economy' and can move away from low-paid work. Public policy support for this job creation is left vague, advocating for lower barriers to entry, reductions in regulatory red tape, and enhancements to the entrepreneurial environment.

In terms of trade policy, South Africa's Trade Policy and Strategic Framework aims to support industrial strategy and identifies the importance of trade in services. The document states that 'the expansion of services is critical to efforts to promote growth, employment and equity' (Department of Trade and Industry 2010: 45). During the Uruguay round of trade negotiations in the 1990s, international trade in services became subject to regulations as set out in the General Agreement on Trade in Services (GATS). South Africa undertook extensive multilateral services commitments and liberalized 92 of 160 services sectors, which is on a par with most of the developed world. In subsequent negotiations on telecommunications and financial services, South Africa signed further GATS protocols. As a result, the South African services market is well developed and fairly open to foreign enterprises.

It is thus evident that South Africa's various policy documents have largely acknowledged the importance of service sector growth as a complement to industrial growth in the evolving global economy. Where services appear in policy documents, this tends to revolve around financial and business services or tourism. Furthermore, South Africa's most recent document, the NDP concentrates on low-wage, domestically orientated, small services industries. While certainly important, it is not evident that these industries will be able to contribute significantly to growth and development, nor provide decent work for low-skilled people. Manufacturing and industrialization remain the central focus of South African policy, and are certainly given more attention than the services sector.

\section{$7 \quad$ Conclusion}

The services sector in South Africa is large and growing. Close to two-thirds of GDP and employment is accounted for by the service economy. Employment growth over the post-2000 period has almost exclusively been driven by growth in service sector jobs. Thus one could argue that South Africa is a de facto service-orientated economy.

It is interesting to consider this growing importance of the services sector in relation to the notion of structural transformation. Since 2000, labour resources have shifted away from lowproductivity industries such as agriculture and accommodation and catering. However, rather than labour resources shifting to high-productivity manufacturing activities, as per the East Asian model, we have seen labour resources shift toward services industries. In fact, one could argue that evidence points to the deindustrialization of the South African economy over the period 2000 to 2014, with both manufacturing and mining industries declining in economic prominence.

Employment patterns in services yield to a particular form of segmentation. Firstly, we observe a slight shift toward high-productivity service industries such as finance and insurance, and 
business services (non-TES). Secondly, there is a significant shift toward relatively highproductivity government services. Finally, we observe a shift toward the low-productivity wholesale and retail trade industry and TES within the business services industry. The highproductivity service industries are skill intensive and thus associated with higher returns to employment. Conversely, the low-productivity service industries are less skill intensive and thus returns to employment are lower. Given the importance of education and skills in the South African labour market, it seems that labour resources are segmented along these lines, and this plays a role in the shaping of the services sector.

The question regarding the sustainability of services-led growth needs to take into account the growth prospects of these three segments. Firstly, the modern high-productivity services industries such as communication, finance and insurance, and business services comprise, on aggregate, increasing shares of GDP and employment. However, the favourable performance of these modern high-productivity services industries is tempered by the fact that employment growth across these three industries has been predominantly driven by growth in business services, of which a significant share is in low-productivity TES. It has been argued here and elsewhere that growth in TES is a result of firms finding a mechanism to obviate labour regulatory restrictions. Nevertheless, these high-productivity services industries, specifically finance and communications, offer great potential to be engines of growth in the South African economy. It is worth noting, however, that the skill intensity associated with these industries suggests that their potential is constrained by the South African schooling system's inability to generate skilled individuals that can be absorbed into these industries. As such, the extent to which there has been a structural shift toward high-productivity modern service industries is limited, and is likely to be constrained in the future.

Secondly, there has been significant employment growth in government services. Government services is, on average, characterized by relatively high-productivity activities, high skill intensity, and thus relatively high wage levels. The high wage levels are in part explained by strong public sector unions. However, this industry cannot act as a driver of growth, given that a bloated public sector is not fiscally sustainable and never a positive contributor to long-run economic development.

Thirdly, the growth in employment of an already substantial wholesale and retail trade industry needs to be considered in light of the high levels of informality in the industry. One could argue that this industry helps absorb the excess supply of low-skilled workers in the South African economy. This is certainly the case where survivalist economic activities in townships and informal settlements in South Africa typically involve retail trade. As such, this industry is unlikely to act as a driver of high-productivity growth.

For the services sector to be a driver of structural transformation and economic growth, it needs to become increasingly export orientated in order to reap the increasing economies associated with a large global marketplace. Services exports in South Africa are relatively small in relation to total exports (approximately 15 per cent) and total services value-added (approximately 7 per cent), with the latter measure suggesting a low tradability of South African services. Given the dominance of the services sector in the domestic economy, there is considerable potential for South Africa to boost the volume of services exports. However, despite its small size, we do observe growth in services exports in the post-1994 period. The question is whether this is a continuing trend, and whether the composition of these service exports is biased toward highquality services exports.

South Africa's services exports remain largely centred on travel and tourism, and on services that support the exports of goods. Unlike other emerging economies, South Africa has not 
experienced a distinct shift away from traditional services exports toward modern, 'hightechnology' exports. South Africa lags behind its emerging market peers with regard to the sophistication of its commercial services exports, especially as communications and ICT exports have remained below 5 per cent of commercial services exports. The poor performance of relatively more sophisticated commercial exports may be a result of domestic factors such as labour market constraints, and inadequate trade policies.

The composition of South Africa's service exports along the destination margin indicates that exports to the developed country markets of Europe and North America are predominantly driven by traditional services, such as tourism and travel services. We also observe a declining relative importance of these developed country markets. Interestingly, the share of service exports to developing countries suggests the growing importance of these markets. Evidence suggests that service exports to these regions is relatively more sophisticated. Therefore, service exports to developing country markets may provide an avenue for export expansion in dynamic high-productivity services. Travel service exports will continue to provide South Africa with a competitive edge in global markets, but there is a need to address possible bottlenecks to growth and specialization of high-quality services exports. It is here where the potential for a more focused service-orientated industrial policy lies.

In light of tourism being a key component of service exports, we examined the tourism industry in more detail. The analysis indicated a substantial contribution to GDP and employment, and an ability to generate employment in the post-2008 period, thus underwriting the importance of the industry. A key aspect of the tourism industry is its propensity to create jobs in relatively marginalized segments of the labour market. For instance, it is able to create jobs for unskilled, youth, and female workers. In addition, a substantial number of these jobs are created in spatially disconnected and economically under-developed areas of South Africa, such as rural areas and seaside towns.

Another potential set of industries that exhibit strong export potential is that of processed agriculture and horticulture. Three important points emerge from the analysis of these exports. Firstly, processed agriculture and horticulture products constitute the largest shares of agriculture exports, with strong growth evident in horticulture exports. Developed country, particularly European, consumers drive demand for these higher-value agriculture exports. In addition, developing country markets, particularly those in Africa, are likely to experience rising incomes in the future, and thus shift to processed foodstuffs. Therefore, South Africa is well placed to exploit this growing demand. Secondly, given the employment-intensive nature of horticulture, there is the potential to generate employment-intensive export-driven growth. Finally, there are substantial spillover effects associated with growth in processed agriculture and horticulture. These activities are closely linked with transport and logistics, packaging, irrigation equipment maintenance, and other linked manufacturing and service activities.

It is important to note that the trade in services data (Section 5.1) is unable to measure a significant component of South Africa's services trade, namely FDI (Mode 3). South Africa's services trade with other African countries is largely FDI and therefore not captured in the TSD. South Africa has a large presence of banks and other financial institutions, retail firms (such as clothing and FMCG retailers), and communications firms (e.g. MTN) on the African continent. This suggests that without these operations accounted for, the value and sophistication of South African services exports, particularly in financial services, may be significantly underestimated. The inability to pick up Mode 3 service exports means that a series of nodes of services development and export potential that are being slowly built-such as TES through South Africa's major corporate entity in this sector, deciding to increase its global footprint in the 
placement services market, and in addition the big three listed South African health services firms expanding into Europe-are not being picked up.

In light of this data limitation, we examined FDI along two dimensions. Firstly, we looked at broad measures of the outflow of South African FDI by destination. Secondly, we present a case study analysis of three successful South African service sector firms that have entered the global marketplace.

The steady growth in South Africa's stock of outbound FDI since 2000 indicates that its companies have become increasingly globalized. This investment abroad is primarily driven by the need to increase revenue streams in light of saturated domestic markets. Although Europe is the primary destination for South African FDI, investment into Africa has grown substantially over the period. Expansion into Africa points to confidence in the growth potential of countries within the continent, and South African firms are ideally situated in order to take advantage of this potential. Investment within the continent has shifted from Southern African markets to East African markets.

The case study analysis provides an indication of the ability of South African service sector firms to access global markets. Analysis across the three firms points to the importance of these foreign markets in sustaining their revenue streams. The analysis also shows increased competition faced by these firms, and thus the need to adapt to an increasingly competitive global business environment. The analysis of South African FDI points to service sector firms that are able to compete globally in the sophisticated high-productivity telecommunications, finance, and health industries.

In conclusion, the services sector in South Africa is diverse and intertwines with the functioning and transformation of the economy in diverse ways. For instance, low-productivity activities in wholesale and retail trade are better able to absorb the abundance of inadequately skilled workers. Industries related to financial service activities align with the notion of highproductivity export-orientated growth industries. And although the potential exists within this industry, it is constrained by the supply of an adequately skilled workforce. In both instances, these industries provide an avenue for employment opportunities and growth, but along different dimensions. Furthermore, the services sector constitutes the majority share of GDP, and as such is a significant $\operatorname{cog}$ in South Africa's economic engine. The question then is whether South Africa can exploit the large existing share of GDP constituted by the services sectorsranging from retail, communication, to financial services and tourism across the entire product market, customer, productivity, and employment spectrum - in order to build a set of globally competitive services firms, which not only continue to create local employment, but also serve to provide the impetus for South Africa's longer-run economic development trajectory.

\section{References}

AT Kearney (2015). 'Retail in Africa: Still the Next Big Thing'. The 2015 African Retail Development Index. Available at: https://www.atkearney.com/documents/10192/6437503/Retail+in+Africa.pdf/b038891c0e81-4379-89bb-b69fb9077425 (accessed on 10 August 2016).

Besedes, T., and T.J. Prusa (2011). 'The Role of Extensive and Intensive Margins and Export Growth'. Journal of Development Economics, 96(2): 371-79. 
Bhorat, H., A. Cassim, and D. Yu (2014). Temporary Employment Services in South Africa: Assessing the Industry's Economic Contribution. Mimeograph. Cape Town: Development Policy Research Unit, University of Cape Town.

Bhorat, H., et al. (2016). 'Investigating the Feasibility of a National Minimum Wage for South Africa'. Development Policy Research Unit Working Paper 201601. Cape Town: Development Policy Research Unit, University of Cape Town.

Bhorat, H., and J. Hodge (1999). 'Decomposing Shifts in Labour Demand in South Africa'. The South African Journal of Economics, 67(3): 155-68.

Bhorat, H., R. Kanbur, and B. Stanwix (2014). 'Estimating the Impact of Minimum Wages on Employment, Wages, and Non-wage Benefits: The Case of Agriculture in South Africa'. American Journal of Agricultural Economics, 96(5): 1402-19.

Bhorat, H., K. Naidoo, M. Oosthuizen, and K. Pillay (2015). 'Demographic, Employment, and Wage Trends in South Africa'. WIDER Working Paper 2015/141. Helsinki: UNU-WIDER.

Bhorat, H., F. Steenkamp, and C. Rooney (2016). 'Africa's Manufacturing Malaise'. UNDP-RBA Working Paper 3/2016. Available at: http://www.africa.undp.org/content/rba/en/home/library/working-papers/africa-smanufacturing-malaise.html (accessed on 4 October 2016 ).

Blinder, A.S. (2006). 'Offshoring: The Next Industrial Revolution?'. Foreign Affairs, 85(2): 113-28.

Bosworth, B., and A. Maertens (2009). 'The Role of the Service Sector in Economic Growth and Employment Generation in South Asia'. In E. Ghani and H. Kharas (eds), The Service Revolution in South Asia. Washington, DC: World Bank.

Brenton, P., and R. Newfarmer (2009). 'Watching More than the Discovery Channel to Diversify Exports'. In R. Newfarmer, W. Shaw, and P. Walkenhorst (eds), Breaking into New Markets: Emerging Lessons for Export Diversification. Washington, DC: The World Bank.

Butler, G., and C.M. Rogerson (2016). 'Inclusive Local Tourism Development in South Africa: Evidence from Dullstroom'. Local Economy, 31(1-2): 246-81.

Cassim, A., K. Lilenstein, M. Oosthuizen, and F. Steenkamp (2016). 'Informality and Inclusive Growth in Sub-Saharan Africa: Evidence and Lessons from Latin America (ELLA)Regional Evidence Paper'. DPRU Working Paper No. 201602. Cape Town: Development Policy Research Unit.

Cattaneo, O. (2010). 'Health Without Borders: International Trade for Better Health Systems and Services'. In O. Cattaneo, M. Engman, S. Sáez, R.M. Stern (eds), International Trade in Services: New Trends and Opportunities for Developing Countries. Washington, DC: World Bank. Available at: https://openknowledge.worldbank.org/bitstream/handle/10986/2476/555440PUB0Int01 EPI1972196101PUBLIC1.pdf?sequence=1 (accessed on 23 August 2015).

Connell, J. (2006). 'Medical Tourism: Sea, Sun, Sand and ... Surgery'. Tourism Management, 27(6): 1093-100.

Daly, J., and G. Gereffi (2017, forthcoming). 'Tourism GVCs and Africa'. WIDER Working Paper 2017/xxx. Helsinki: UNU-WIDER.

Department of Economic Developement (2011). The New Growth Path: Framework. Pretoria: Department of Economic Development, Republic of South Africa.

Department of Trade and Industry (2010). A South African Trade Policy and Strategy Framework. Pretoria: Department of Trade and Industry, Republic of South Africa. 
Department of Trade and Industry (2014). Industrial Policy Action Plan: Economic Sectors and Employment Cluster IPAP 2014/15-2016/17. Pretoria: The Department of Trade and Industry, Republic of South Africa.

Draper, P., N. Khumalo, and M. Stern (2008). 'Why Isn't South Africa More Proactive in International Services Negotiations?'. In J.A. Marchetti and M. Roy (eds), Opening Markets for Trade in Services: Countries and Sectors in Bilateral and WTO Negotiations. Cambridge: Cambridge University Press.

Edwards, L. (2001). 'Trade and the Structure of South African Production, 1984-97'. Development Southern Africa, 18(4): 471-91.

Edwards, L., and P. Alves (2006). 'South Africa's Export Performance: Determinants of Export Supply'. South African Journal of Economics, 74(3): 473-500.

Edwards, L., and R. Lawrence (2008). 'South African Trade Policy Matters'. Economics of Transition, 16(4): 585-608.

Engman, M. (2010). 'Exporting Information Technology Services: In the Footsteps of India'. In O. Cattaneo, M. Engman, S. Sáez, and R.M. Stern (eds), International Trade in Services: New Trends and Opportunities for Developing Countries. Washington, DC: World Bank. Available at: https://openknowledge.worldbank.org/bitstream/handle/10986/2476/555440PUB0Int01 EPI1972196101PUBLIC1.pdf?sequence=1 (accessed on 13 October 2016).

Fourie, J. (2011). 'Travel Service Exports as Comparative Advantage in South Africa'. South African Journal of Economic and Management Sciences, 14(2): 210-28.

Francois, J., and O. Pindyuk (2013). 'Consolidated Data on International Trade in Service V8.9'. IIDE Discussion Paper 20130101. Washington, DC: World Bank.

Freytag, A. (2011). 'Cumulative Costs of Trade Protection in the South African Economy'. South African Institute of International Affairs (SAIIA), Occasional Paper No 80. Johannesburg: South African Institute of International Affairs.

Fukase, E., and W. Martin (2016). 'Agro-processing and Horticultural Exports from Africa'. UNU-WIDER Industries Without Smokestacks Mimeograph. Available at: https://www.wider.unu.edu/sites/default/files/Blog/PDF/Will Martin.pdf (accessed on 7 October 2016).

Ghani, E. (2009). 'Is Service-led Growth a Miracle for South Asia?'. In E. Ghani and H. Kharas (eds), The Service Revolution in South Asia. Washington, DC: World Bank.

Ghani, E., and H. Kharas (2009). 'The Service Revolution in South Asia: an Overview'. In E. Ghani and H. Kharas (eds), The Service Revolution in South Asia. Washington, DC: World Bank. Available at: http:/ / documents.worldbank.org/curated/en/2009/06/11418589/service-revolutionsouth-asia (Accessed on 11 August 2016).

Ghani, E., and S. O'Connell (2014). 'Can Service Growth be a Growth Escalator in Low Income Countries?'. Policy Research Working Paper 6971, World Bank. Washington, DC: World Bank. Available at: http://hdl.handle.net/10986/19352 (accessed on 16 August 2016).

Global Impact Investment Network (2015). The Landscape for Impact Investing in West Africa: Understanding the Current Status, Trends, Opportunities, and Challenges. New York: Global Impact Investment Network. Available at: https://thegiin.org/knowledge/publication/westafricareport (accessed on 26 September 2016). 
GSMA (2015). The Mobile Economy: Sub-Saharan Africa 2015'. London: GSMA. Available at:

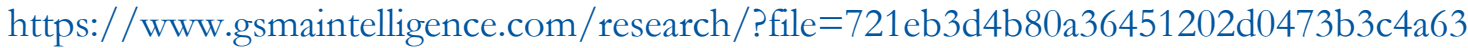
\&download (accessed on 3 October 2016 ).

GSMA (2016). 'Operator Group Ranking, 2015'. Available at: https://www.gsmaintelligence.com/research/?file=ab4233bd974a8f135aa851377071d70a\& download (accessed on 12 August 2016).

Hartley, W., and B. Phakathi (2015). 'Relaxation of Parts of Visa Rules Welcomed'. Business Day. Available at: http://www.pressreader.com/south-africa/businessday/20151026/281642484029293 (accessed on 16 September 2016).

Hoekman, B., and A. Mattoo (2008). 'Services Trade and Growth'. World Bank Policy Research Working Paper 4461. Washington, DC: World Bank.

IMF (International Monetary Fund) (2016a). 'South Africa's Outlook Shows Urgent Need for Policy Reforms'. Available at: http://www.imf.org/en/News/Articles/2016/07/08/17/06/South Africa Latest Outlook Shows Urgent Need for Policy Reforms (accessed on 10 August 2016).

IMF (International Monetary Fund) (2016b). World Economic Outlook: Too Slow for too Long. Washington, DC: International Monetary Frund. Available at: http://www.imf.org/external/pubs/ft/weo/2016/01/pdf/text.pdf (accessed on 13 September 2016).

Khanna, A., P. Papadavid, J. Tyson, and D. Willem te Velde (2016). 'The Role of Services in Economic Transformation: With an Application to Kenya'. Supporting Economic Transformation Paper. London: ODI, DFID.

Koenker, R., and G. Basset (1978). 'Regression Quantiles'. Econometrica, 46(1): 33-50.

Koenker, R., and K.F. Hallock (2001). 'Quantile Regression'. Journal of Economic Perspectives, 15(4): 143-56.

Levy, P.I. (1999). 'Sanctions on South Africa: What Did they Do?'. Center Discussion Paper No. 796. New Haven, CT: Economic Growth Center, Yale University.

Ligthelm, A. (2008). 'The Impact of Shopping Mall Development on Small Township Retailers'. South African Journal of Economic and Management Sciences, 11(1): 37-53.

van der Marel, E. (2011). 'Determinants of Comparative Advantage in Services'. Group d'Economie Mondiale Working Paper. Paris: Group d'Economie Mondiale. Available at: http://gem.sciences-po.fr/index.html (accessed on 29 September 2015).

McMillan, M.S., and K. Harttgen (2014). 'What is Driving the "African Growth Miracle"?'. NBER Working Paper No. 20077. Cambridge, MA: National Bureau of Economic Research.

McMillan, M., D. Rodrik, and Í. Verduzco-Gallo, (2014). 'Globalization, Structural Change, and Productivity Growth, with an Update on Africa'. World Development, 63: 11-32. Available at: http://www.sciencedirect.com/science/article/pii/S0305750X13002246 (accessed on 8 September 2015).

Melitz, M.J. (2003). 'The Impact of Trade on Intra-Industry Reallocations and Aggregate Industry Productivity'. Econometrica, 71(6): 1695-725.

Mishra, S., S. Lundström, and R. Anand (2011). 'Service Export Sophistication and Economic Growth’. World Bank Policy Research Working Paper 5606. Washington, DC: World Bank. 
MTN (2006). Annual Report 2006. [Online]. Available at: https://www.mtn.com/Investors/FinancialReporting/Documents/ANNUALREPORTS/ 2006/Booklet/ar_shareholder_booklet_2006.pdf (accessed on 15 August 2016).

MTN (2007). Annual Report 2007. [Online]. Available at: https://www.mtn.com/Investors/FinancialReporting/Documents/ANNUALREPORTS/ 2007/Booklet/ar_shareholder_booklet_2007.pdf (accessed on 15 August 2016).

MTN (2008). Annual Report 2008. [Online]. Available at: https://www.mtn.com/Investors/FinancialReporting/Documents/ANNUALREPORTS/ 2008/Booklet/annual_results_2008_shareholder_booklet.pdf (accessed on 15 August 2016).

MTN (2009). Annual Report 2009. [Online]. Available at: https://www.mtn.com/Investors/FinancialReporting/Documents/ANNUALREPORTS/ 2009/Booklet/annual_results_2009_shareholder_booklet.pdf (accessed on 15 August 2016).

MTN (2010). Annual Report 2010. [Online]. Available at: https://www.mtn.com/Investors/FinancialReporting/Documents/ANNUALREPORTS/ 2010/Booklet/annual_results_2010_shareholder_booklet.pdf (accessed on 15 August 2016).

MTN (2011). Annual Report 2011. [Online]. Available at: https://www.mtn.com/Investors/FinancialReporting/Documents/ANNUALREPORTS/ 2011/Booklet/booklet\%20.pdf (accessed on 15 August 2016).

MTN (2012). Annual Report 2012. [Online]. Available at: https://www.mtn.com/Investors/FinancialReporting/Documents/ANNUALREPORTS/ 2012/Booklet/booklet_2012.pdf (accessed on 15 August 2016).

MTN (2013). Annual Report 2013. [Online]. Available at: https://www.mtn.com/Investors/FinancialReporting/Documents/ANNUALREPORTS/ 2013/Booklet/Annual_results_booklet_2013.pdf (accessed on 15 August 2016).

MTN (2014). Annual Report 2014. [Online]. Available at: https://www.mtn.com/Investors/FinancialReporting/Documents/ANNUALREPORTS/ 2014/Booklet/Annual_results_booklet_2014.pdf (accessed on 15 August 2016).

MTN (2015). Annual Report 2015. [Online]. Available at: https://www.mtn.com/Investors/FinancialReporting/Documents/ANNUALREPORTS/ 2015/Booklet/Annual_results_booklet_2015.pdf (accessed on 15 August 2016).

NaRanong, A., and V. NaRanong (2011). 'The Effects of Medical Tourism: Thailand's Experience'. Bulletin of the World Health Organization, 89(5): 336-44.

National Planning Commission (2013). National Development Plan 2030: Our Future-Make it Work. Pretoria: The Presidency, Republic of South Africa.

Netcare (2009). Results Booklet. [Online]. Available at: http://www.netcareinvestor.co.za/pdf/annual_results/full_2009.pdf (accessed on 16 August 2016).

Netcare (2010). Results Booklet. [Online]. Available at: http://www.netcareinvestor.co.za/reports/netcare_annual_10/pdf/full_new.pdf (accessed on 16 August 2016).

Netcare (2011). Results Booklet. [Online]. Available at: http://www.netcareinvestor.co.za/reports/netcare_annual_11/pdf/booklet.pdf (accessed on 16 August 2016). 
Netcare (2012). Results Booklet. [Online]. Available at: http://www.netcareinvestor.co.za/reports/netcare_annual_12/pdf/booklet.pdf (accessed on 16 August 2016).

Netcare (2013). Results Booklet. [Online]. Available at: http://www.netcareinvestor.co.za/reports/netcare_annual_13/pdf/booklet.pdf (accessed on 16 August 2016).

Netcare (2014). Results Booklet. [Online]. Available at: http://www.netcareinvestor.co.za/rep_annual_results_2014.php (accessed on 16 August 2016).

Netcare (2015). Results Booklet. [Online]. Available at: http://www.netcareinvestor.co.za/reports/netcare_annual_15/pdf/booklet.pdf (accessed on 16 August 2016).

Netcare (2016). Divisions. [Online]. Available at: http://www.netcare.co.za/Who-WeAre/Group-at-a-glance/Divisions (accessed on 16 August 2016).

Noland, M., D. Park, and G. Estrada (2012). 'Developing the Service Sector As Engine of Growth for Asia: An Overview'. ADB Economics Working Paper Series No. 320. Available at: http://hdl.handle.net/11540/1270 (accessed on 15 September 2016 ).

Oxford Business Group (2015). 'New Visa Rules a Barrier to Expanding South African Tourism Sector'. Available at: https://www.oxfordbusinessgroup.com/overview/challenge-growthnew-visa-rules-prove-be-barrier-sector-expansion (accessed on 16 September 2016).

Oxford Business Group (2016). 'Kenya's Retail Sector Ranks as Second-most Formalised in Africa'. Available at: http://www.oxfordbusinessgroup.com/news/kenya $\%$ E2\%80\% $\% 99$ sretail-sector-ranks-second-most-formalised-africa (accessed on 10 August 2016).

Phiri, A. (2016). 'Tourism and Economic Growth in South Africa: Evidence from Linear and Nonlinear Cointegration Frameworks'. Managing Global Transitions: International Research Journal, 14(1): 31-53.

Pieterse, D., A. Steenkamp, and J. Rycroft (2016). Boosting Agricultural Production and Achieving Agrarian Transformation: Lessons from Successful Joint-ventures throughout South Africa. Mimeograph. Pretoria: National Treasury.

Quantec (2016). 'Quantec'. [Online]. Retrieved from Quantec Database: http://www.quantec.co.za/about/ (accessed in August 2016).

Rasool, F., and C.J. Botha (2011). 'The Nature, Extent and Effect of Skills Shortages on Skills Migration in South Africa'. SA Journal of Human Resource Management, 9(1): 1-12.

Reed, J., and F. Guerrera (2006). 'MTN in \$5.5bn Agreed Takeover of Investcom'. Financial Times. Available at: https://www.ft.com/content/caa8b536-da21-11da-b7de-0000779e2340 (accessed on 10 August 2016).

Regmi, A., M.J. Gehlhar, J. Wainio, T.L. Vollrath, P.V. Johnston, and N. Kathuria (2005). 'Market Access for High-Value Foods'. Agricultural Economic Report Number 840, United States Department of Agriculture. Available at: http://purl.umn.edu/33999 (accessed on 3 October 2016).

Rodrik, D. (2014). ‘An African Growth Miracle?’ NBER Working Paper No. 20188. Cambridge, MA: National Bureau of Economic Research.

Saarinen, J., C.M. Rogerson, and H. Manwa (2013). 'Tourism and the Millenium Development Goals: Tourism, Local Communities and Development'. London: Routledge. 
Saez, S., D. Taglioni, E. van der Marel, C.H. Hollweg, and V. Zavacka (2014). Valuing Services in Trade: A Toolkit for Competitiveness Diagnostics. Washington, DC: World Bank Group. Available at: http://documents.worldbank.org/curated/en/2015/01/23811491/valuing-servicestrade-toolkit-competitiveness-diagnostics (accessed on 7 October 2016).

Santana-Gallego, M., J. Rossello-Nadal, and J. Fourie (2016). 'The Effects of Terrorism, Crime and Corruption on Tourism'. ERSA Working Paper 595. Cape Town: Economic Research South Africa.

SARB (South African Reserve Bank) (2016). Sabor - Historical Data. Available at: https://www.resbank.co.za/Markets/DataAndAuctionResults/Pages/Data.aspx (accessed in June 2016).

Shoprite (2010). Annual Report 2010: Gearing for Growth. [Online]. Available at: http://www.shopriteholdings.co.za/InvestorCentre/Documents/2010/2010_ShopriteAR_ Eng.pdf (accessed on 11 August 2016).

Shoprite (2011). Annual Report 2011: Competing With the Right Strategy. [Online]. Available at: http://www.shopriteholdings.co.za/InvestorCentre/Documents/2011/Annual\%20Report \%202011\%20English_web.pdf (accessed on 11 August 2016).

Shoprite (2012). Annual Report 2012: Africa's Largest Food Retailer. [Online]. Available at: http://www.shopriteholdings.co.za/InvestorCentre/Documents/2012/4521_Shoprite\%20 WEB\%20Integrated\%20Report\%20E.pdf (accessed on 11 August 2016).

Shoprite (2013). Annual Report 2013. [Online]. Available at: http://www.shopriteholdings.co.za/InvestorCentre/Documents/2013/Shoprite_2013_Inte grated_Report.pdf (accessed on 11 August 2016).

Shoprite (2014). Annual Report 2014: Low Price Leadership for Tomorrow's Leader. [Online]. Available at:

http://www.shopriteholdings.co.za/InvestorCentre/Documents/2014/IntergratedReport2 014/5206_Integrated_Report.pdf (accessed on 11 August 2016).

Shoprite

(2015a).

'History'.

Available

at: http://www.shopriteholdings.co.za/OurGroup/Pages/History.aspx (accessed on 10 August 2016).

Shoprite (2015b). Annual Report 2015. [Online]. Available at: http://www.shopriteholdings.co.za/InvestorCentre/Documents/2015/IntegratedReport20 15/Eng/5527_SR_IR2015_E.pdf (accessed on 11 August 2016).

Standard Bank (2010). Annual Integrated Report 2010. [Online]. Available at: http://annualreport2010.standardbank.com/downloads/standardbank_ar_2010.pdf (accessed on 25 August 2016).

Statistics South Africa (n.d.). Quarterly Labour Force Survey. Available at: Statistics South Africa Nesstar Database: http://interactive.statssa.gov.za:8282/webview/ (accessed in May 2016).

Statistics South Africa (2012). TSA 2005-2012 Final. [Data file]. Available at: http://www.statssa.gov.za/publications/Report-04-05-07/TSA_2005-2012_final.zip (accessed on 5 September 2016).

Statistics South Africa (2014). Labour Market Dynamics Survey. Available at: http://interactive.statssa.gov.za:8282/webview/ (accessed in May 2016).

Statistics South Africa (2015a). TSA 2013-2014 Prelim. [Data file]. Available at: http://www.statssa.gov.za/publications/Report-04-05-07/TSA_2013-2014_prelim.zip (accessed on 5 September 2016). 
Statistics South Africa (2015b). Mid-Year Population Estimates: 2015. [Online]. Available at: https://www.statssa.gov.za/publications/P0302/P03022015.pdf (accessed on 10 August 2016).

Stones, L. (2015). 'Why Mauritius Whips South Africa at Doing Business'. Rand Daily Mail. Available at: http://www.rdm.co.za/business/2015/08/31/why-mauritius-whips-southafrica-at-doing-business (accessed on 22 September 2016).

UNCOMTRADE (n.d.). World Intergrated Trade Solutions. Available at: http:/ /wits.worldbank.org/Default.aspx?lang=en (accessed in August 2016).

UNCTAD (2014). Bilateral FDI Statistics 2014. Retrieved from UNCTAD Bilateral FDI Database: $\quad$ http://unctad.org/en/Pages/DIAE/FDI\%20Statistics/FDI-StatisticsBilateral.aspx (accessed in August 2016).

UNWTO (2015). UNWTO Tourism Highlights, 2015 Edition. Madrid: World Tourism Organisation (UNWTO). Available at: http://www.e-unwto.org/doi/book/10.18111/9789284416899 (accessed on 7 September 2016).

World Bank. (2016a). World Development Indicators. Available at: http:// databank.worldbank.org/data/home.aspx (accessed in June 2016).

World Bank. (2016b). Trade in Services Database. Available at: http://data.worldbank.org/datacatalog/trade-in-services (accessed in June 2016).

WTCC (2014). Gender, Equality and Youth Employment: Travel and Tourism As a Key Employer of Women and Young People. London: World Travel \& Tourism Council. Available at: http://www.wttc.org/research/policy-research/human-capital/gender-equality-and-youthemployment-in-travel-tourism/ (accessed on 13 September 2016). 


\section{Appendix}

\section{Services exports: data definitions and caveats}

In general, data on the trade in services is far from comparable to data on the trade in goods, given the uniqueness of international service transactions, compared to cross-border trade in goods. Services are intangible, cannot be stored, and often require joint production with consumers. The World Trade Organisation has therefore classified trade in services along four Modes of supply:

- Mode 1: Cross-border trade-services supplied from the territory of one country into the territory of another.

- Mode 2: Consumption abroad-services supplied in the territory of a country to the consumer of another.

- Mode 3: Commercial presence-services supplied in the territory of a country to the consumers of another (i.e. FDI).

- Mode 4: Presence of natural persons-services supplied by nationals of a country in the territory of another.

However, balance of payments and other trade statistics typically only record services trade in Modes 1, 2, and 4. Mode 3 is particularly difficult to measure, although it makes up a large proportion of services trade. For the purposes of this paper, it is assumed that services exports data falls within Modes 1 and 2 only.

\section{Data definitions}

The indicators of services exports used in this paper have been drawn from the following datasets: World Development Indicators, Trade in Services Database, and the South African Reserve Bank. The definitions of services exports in each of these sources varies slightly. For data from World Development Indicators, the definitions in Table A1 are assumed.

Table A1: World Development Indicators definitions

\begin{tabular}{|l|l|l|}
\hline Exports category & Explanation & Source \\
\hline Service exports (BoP) & $\begin{array}{l}\text { Services refer to economic output of intangible } \\
\text { commodities that may be produced, transferred, and } \\
\text { consumed at the same time. }\end{array}$ & $\begin{array}{l}\text { International Monetary } \\
\text { Fund, Balance of } \\
\text { Payments Statistics } \\
\text { Yearbook and data } \\
\text { files. }\end{array}$ \\
\hline Commercial service exports & $\begin{array}{l}\text { Commercial service exports are total service exports } \\
\text { minus exports of government services not included } \\
\text { elsewhere. International transactions in services are } \\
\text { defined by the IMF's Balance of Payments Manual } \\
\text { (1993) as the economic output of intangible } \\
\text { commodities that may be produced, transferred, and } \\
\text { consumed at the same time. Definitions may vary } \\
\text { among reporting economies. }\end{array}$ & $\begin{array}{l}\text { International Monetary } \\
\text { Pand, Balance of } \\
\text { Yearbook and data } \\
\text { files. }\end{array}$ \\
\hline Goods exports (BoP) & $\begin{array}{l}\text { Goods exports refer to all movable goods (including } \\
\text { non-monetary gold and net exports of goods under } \\
\text { merchanting) involved in a change of ownership from } \\
\text { residents to non-residents. }\end{array}$ & $\begin{array}{l}\text { International Monetary } \\
\text { Pand, Balance of } \\
\text { Yearbook and data } \\
\text { files. }\end{array}$ \\
\hline Merchandise exports & $\begin{array}{l}\text { Merchandise exports show the f.o.b. value of goods } \\
\text { provided to the rest of the world. }\end{array}$ & $\begin{array}{l}\text { World Trade } \\
\text { Organization. }\end{array}$ \\
\hline
\end{tabular}


For data from the Trade in Services Database, the definitions in Table A2 are assumed.

Table A2: Trade in Services Database definitions

\begin{tabular}{|c|c|}
\hline Services category & Explanation \\
\hline Transport & $\begin{array}{l}\text { Transport services consist of passenger, freight and other transport for sea, air, } \\
\text { road, rail, inland waterway transport, space transport, pipeline transport and } \\
\text { electricity transmission, and other supporting transport services. }\end{array}$ \\
\hline Travel & $\begin{array}{l}\text { Travel services consists of business and personal travel (but does not include } \\
\text { transportation), and includes education- and health-related expenditures. Travel } \\
\text { services can also be interpreted as international tourism. }\end{array}$ \\
\hline Government services & $\begin{array}{l}\text { Government services consist of services relating to embassies and consulates, } \\
\text { military units and agencies, and other government services. }\end{array}$ \\
\hline Communication & $\begin{array}{l}\text { Communication services comprise postal and courier services, and } \\
\text { telecommunications services. }\end{array}$ \\
\hline Construction & $\begin{array}{l}\text { Construction services comprise construction abroad and construction in the } \\
\text { compiling economy. }\end{array}$ \\
\hline Insurance & $\begin{array}{l}\text { Insurance services include life insurance and pension funding, freight insurance, } \\
\text { other direct insurance, reinsurance, and auxiliary services. }\end{array}$ \\
\hline Finance & $\begin{array}{l}\text { Financial services consist of financial intermediary services, not including } \\
\text { insurance services. }\end{array}$ \\
\hline Computer and information & $\begin{array}{l}\text { Computer and information services consist of computer services, such as data } \\
\text { processing and hardware, and information services. }\end{array}$ \\
\hline Royalties and licence fees & $\begin{array}{l}\text { Royalties and licence fees include payments for intangible assets or property } \\
\text { rights, patents, copyrights, etc. }\end{array}$ \\
\hline Other business & $\begin{array}{l}\text { Other business services comprise: (i) merchanting and other trade-related } \\
\text { services; (ii) operational leasing services; and (iii) miscellaneous business, } \\
\text { professional, and technical services, which are made up of (a) legal, accounting, } \\
\text { management consulting, and public relations, (b) advertising, market research, } \\
\text { (c) research and development (d) architectural, engineering, and other technical } \\
\text { services, (e) agricultural, mining, and on-site processing services, (f) other } \\
\text { business services, and (e) services between related enterprises. }\end{array}$ \\
\hline $\begin{array}{l}\text { Personal, cultural and } \\
\text { recreational }\end{array}$ & $\begin{array}{l}\text { Personal and recreational services consist of audiovisual and related services, } \\
\text { and other personal, cultural and recreational services. }\end{array}$ \\
\hline
\end{tabular}

Source: World Development Indicators (World Bank 2016a)

\section{Problems with Trade in Services Database}

The Trade in Services Database provides a consolidated dataset of multiple sources of bilateral trade in services data, including OECD, Eurostat, UN, and IMF. However, the database is problematic. Firstly, the data captures only the first two Modes of services trade, and as such, value and volumes of services trade may be underestimated. Secondly, the database does not fully capture South-South trade, given that trade in services in developing and emerging market countries is typically unreported, if not poorly reported. While the addition of the 'XWD' region ensures that the data is internally consistent-and can therefore be used as a proxy for developing countries with poor data reporting - it should ideally decrease over time as data quality improves. This was not found to be the case, particularly for South Africa's unallocated services exports. Thirdly, while the database provides incredible detail on the type of services traded between countries, there were considerable gaps and inconsistencies the more disaggregated the data became, at least for South Africa. In some cases, there are no data entries for sub-categories, which may indicate no services exports in respective sub-categories, or insufficient data to complete the entry. It is therefore difficult to assess growth into new service sectors, as the trend may be influenced largely by data reporting issues. In other cases, reported totals do not add up to the summation of sub-category figures, making it difficult to ascertain the accuracy of the data. These are issues that have been well noted by the architects of the database. Until the quality of reporting services trade improves, it can be assumed that the Trade in Services Database provides a close approximation of services trade. 
Table A3: Top 20 agriculture products, 2014

\begin{tabular}{|c|c|c|c|c|}
\hline HS6 & Name & $\begin{array}{l}\text { Product } \\
\text { category }\end{array}$ & $\begin{array}{l}\text { Share of } \\
\text { total } \\
\text { exports }\end{array}$ & $\begin{array}{l}\text { Share of } \\
\text { agriculture } \\
\text { exports }\end{array}$ \\
\hline 080510 & Oranges & $\mathrm{H}$ & 0,73 & 6,9 \\
\hline 080610 & Grapes fresh & $\mathrm{H}$ & 0,73 & 6,9 \\
\hline 220421 & $\begin{array}{l}\text { Other wine, grape must (fermentation arrested; in containers } \\
2 \text { l or Less) }\end{array}$ & $P$ & 0,48 & 4,5 \\
\hline 080810 & Apples & $\mathrm{H}$ & 0,34 & 3,2 \\
\hline 030420 & $\begin{array}{l}\text { Frozen fillets: cod halibut, fresh-water catfish, tilapia, Alaska } \\
\text { pollock }\end{array}$ & $P$ & 0,33 & 3,1 \\
\hline 170111 & $\begin{array}{l}\text { Cane sugar: raw sugar not containing added flavouring or } \\
\text { colouring matter }\end{array}$ & SP & 0,31 & 3,0 \\
\hline 100590 & Maize (not seed) & B & 0,31 & 2,9 \\
\hline 220429 & $\begin{array}{l}\text { Other wine, grape must (fermentation arrested; not in } \\
\text { containers } 2 \text { l or Less) }\end{array}$ & $P$ & 0,25 & 2,4 \\
\hline 080530 & $\begin{array}{l}\text { Lemons (citrus limon, citrus limonum) and limes (citrus } \\
\text { aurantifolia) }\end{array}$ & $\mathrm{H}$ & 0,25 & 2,4 \\
\hline 510111 & Shorn wool (greasy; not carded or combed) & SP & 0,24 & 2,3 \\
\hline 030379 & $\begin{array}{l}\text { Tilapia (tilapiinae), mullet, monkfish (lophius spp), butterfish, } \\
\text { sablefish (anoplopoma fimbria) }\end{array}$ & $P$ & 0,23 & 2,2 \\
\hline 080290 & Pecans & $\mathrm{H}$ & 0,23 & 2,1 \\
\hline 080820 & Pears and quinces & $\mathrm{H}$ & 0,22 & 2,1 \\
\hline 080520 & $\begin{array}{l}\text { Mandarins (including tangerines and satsumas); clementines, } \\
\text { wilkings and similar citrus hybrids: }\end{array}$ & $\mathrm{H}$ & 0,17 & 1,6 \\
\hline 290513 & Butan-1-01 (N-butyl alcohol) & SP & 0,16 & 1,5 \\
\hline 382490 & Chemical products and residual products of chemicals & SP & 0,16 & 1,5 \\
\hline 080540 & Grapefruit & $\mathrm{H}$ & 0,15 & 1,4 \\
\hline 210690 & Other food preparations & $P$ & 0,14 & 1,4 \\
\hline 020130 & $\begin{array}{l}\text { Meat of Bovine animals, fresh or chilled. Boneless: processed } \\
\text { and other }\end{array}$ & $P$ & 0,14 & 1,3 \\
\hline 100510 & Seed & $\mathrm{B}$ & 0,13 & 1,3 \\
\hline
\end{tabular}

Notes: 1. $\mathrm{H}$ = Horticulture; $\mathrm{P}=$ Processed; $\mathrm{SP}=$ Semi-processed; $\mathrm{B}=$ Bulk.

Source: Authors' calculations using trade data from the UN COMTRADE WITS dataset (UNCOMTRADE n.d.). 